Article

\title{
Immature Seed Endosperm and Embryo Proteomics of the Lotus (Nelumbo Nucifera Gaertn.) by One-Dimensional Gel-Based Tandem Mass Spectrometry and a Comparison with the Mature Endosperm Proteome
}

\author{
Carlo F. Moro ${ }^{1}$, Yoichiro Fukao ${ }^{2,3}$, Junko Shibato ${ }^{4}$, Randeep Rakwal 4,5,6,7,*, \\ Ganesh Kumar Agrawal ${ }^{6,7, *}$, Seiji Shioda ${ }^{4}$, Yoshiaki Kouzuma ${ }^{1}$ and Masami Yonekura ${ }^{1}$ \\ 1 Laboratory of Molecular Food Functionality, College of Agriculture, Ibaraki University, Ami, \\ Ibaraki 300-0393, Japan; E-Mails: carlofm@gmail.com (C.F.M.); kouzuma@mx.ibaraki.ac.jp (Y.K.); \\ yonekura@mx.ibaraki.ac.jp (M.Y.)
}

2 Plant Global Educational Project, Nara Institute of Science and Technology, Ikoma, Nara 630-0192, Japan; E-Mail: y-fukao@fc.ritsumei.ac.jp

3 Department of Bioinformatics, Ritsumeikan University, Kusatsu, Shiga 525-8577, Japan

4 Global Research Center for Innovative Life Sciences, Hoshi University School of Pharmacy and Pharmaceutical Sciences, 2-4-41 Ebara, Shinagawa, Tokyo 142-8501, Japan;

E-Mails: rjunko@nifty.com (J.S.); shioda@hoshi.ac.jp (S.S.)

5 Faculty of Health and Sport Sciences \& Tsukuba International Academy for Sport Studies (TIAS), University of Tsukuba, 1-1-1 Tennodai, Tsukuba, Ibaraki 305-8574, Japan

6 Research Laboratory for Biotechnology and Biochemistry (RLABB), GPO 13265, Kathmandu 44600, Nepal

7 GRADE (Global Research Arch for Developing Education) Academy Pvt., Ltd., Adarsh Nagar-13, Birgunj 44300, Nepal

* Authors to whom correspondence should be addressed; E-Mails: plantproteomics@ gmail.com (R.R.); gkagrawal123@gmail.com (G.K.A.); Tel.: +81-029-853-5837 (R.R.)

Academic Editor: Jacek R. Wisniewski

Received: 5 July 2015 / Accepted: 7 August 2015 / Published: 14 August 2015

\begin{abstract}
Lotus (Nelumbo nucifera Gaertn.) seed proteome has been the focus of our studies, and we have recently established the first proteome dataset for its mature seed endosperm. The current study unravels the immature endosperm, as well as the embryo proteome, to provide a comprehensive dataset of the lotus seed proteins and a comparison between the mature and immature endosperm tissues across the seed's development.
\end{abstract}


One-dimensional gel electrophoresis (SDS-PAGE) linked with tandem mass spectrometry provided a protein inventory of the immature endosperm (122 non-redundant proteins) and embryo (141 non-redundant proteins) tissues. Comparing with the previous mature endosperm dataset (66 non-redundant proteins), a total of 206 non-redundant proteins were identified across all three tissues of the lotus seed. Results revealed some significant differences in proteome composition between the three lotus seed tissues, most notably between the mature endosperm and its immature developmental stage shifting the proteins from nutrient production to nutrient storage.

Keywords: 1-DGE; LC-MS/MS; lotus; seed; proteome analysis; plant proteomics

\section{Introduction}

Nelumbo nucifera (Gaertn.) is an aquatic perennial belonging to the family of Nelumbonaceae, whose most used common name is the lotus. The lotus typically grows in shallow ponds, with its rhizomes under the mud and its large leaves rising on stalks 1-2 $\mathrm{m}$ above the water surface. Flowers are white to rosy, sweet-scented, solitary, hermaphrodite and $10-25 \mathrm{~cm}$ in diameter, while its fruits are ovoid having nut like achenes. Seeds are black, hard and ovoid [1]. In its immature form, the lotus seed is initially of a yellowish color (early stages) and becomes green as it grows and matures. In its late immature stages, the seed is a $1.2-1.5 \mathrm{~cm}$ long ovoid covered in a soft green husk containing a moist and soft endosperm and the developing embryo. When the seed reaches maturity, the husk turns dark brown and hardens, and both the endosperm and embryo become considerably dry. The lotus embryo, or germ, is a small, stalk-like tissue at the core of the lotus seed. The embryo is green and yellow in color. In the mature seed, the embryo tissue is dry, and while inside an intact seed, it can remain viable for germination for more than a thousand years, making it the most durable seed known [2-5]. The immature seed, which is composed largely of the endosperm, has a water content of $77.5 \%$, as opposed to the $13.1 \%$ water content of the mature seed. The immature seed also has lower protein and carbohydrate content, $5.9 \%$ and $14.9 \%$, respectively, compared to $19.1 \%$ and $62.6 \%$ for the mature seed [6].

The lotus seeds and rhizome are extensively consumed as food in China and Japan and regarded as a health food [7-9], and the plant is also utilized as a source of traditional medicine in India and China [1,10]. Furthermore, extracts from the lotus leaves, rhizomes, and seeds have been shown possess multiple health benefits and a diverse amount of secondary metabolites (more details are given in our review [11] and references therein). The genome of the lotus has only recently been sequenced [12], and a few targeted genome and transcriptome-level works have led to the identification of some functional proteins, as well as their successful cloning and transgenic expression [13-16]. Considering its documented health benefits and several desirable characteristics for nutritional, agricultural and scientific uses, such as its protein content, ability to be cultivated in flooded areas, growth and germination vigor, and extreme seed durability, the lotus plant would consist of an excellent candidate as a crop, source of recombinant genes, or even as potential model organism. However, despite these 
characteristics, proteome analysis of the plant is still at the initial stages of research. Figure 1 depicts the lotus fruit and seed, its importance and proteomic study goals.

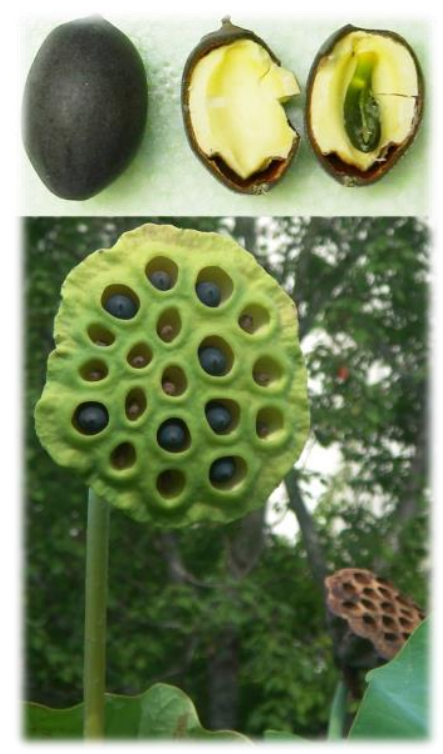

\section{IMPORTANCE OF LOTUS PLANT \& SEED}

* Underused source of proteins and nutrients.

* Extracts have a high potential in medicinal use.

* Agricultural production possible in flooded land.

* Resilient crop with extremely long-lived seeds.

* Seed is a rich source of proteins.

* Potentially useful model organism.

\section{LOTUS PROTEOMICS RESEARCH GOALS}

* Establishing protein extraction protocols \& generating proteome datasets to expand on the known protein inventory.

* Identifying key metabolism proteins, and proteins of interest for health or medicinal use.

* Identifying potential target proteins for transgenic expression.

* Proteome of the different developmental stages.

* Proteome comparison with the other plant seeds.

Figure 1. Overview of the significance and goals of the proteomic research of the lotus. The fruit (seedpod) with seeds from a lotus plant growing in Ibaraki University pond, and the open seed with endosperm and embryo is shown.

Aiming to develop a proteome catalogue of the lotus plant — starting with its seed, the nutrient rich food source - the first study by our research group has unraveled the mature endosperm proteome of the lotus seed, which included the establishment of protocols for protein extraction and analyses by one-dimensional gel electrophoresis (1-DGE) and by two-dimensional gel electrophoresis (2-DGE) in conjunction with mass spectrometry [17]. In the present work, we advance our study of the lotus seed by further analyzing the endosperm of the lotus seed in its immature stage and the embryo, the other prominent component of the mature seed, by utilizing 1-DGE linked with tandem mass spectrometry proteomic approach. The resulting proteome from each tissue (immature endosperm and embryo) is compared with the mature endosperm proteins in hope to bring to light any notable differences in protein content between the different tissue locations and developmental stages.

\section{Experimental Section}

\subsection{Plant Material and Tissues (Immature Endosperm and Embryo of Lotus Seed) Preparation}

Lotus seeds, both mature and immature, were obtained from a small cultivation pond in the Ibaraki University's College of Agriculture campus in Ami town, Ibaraki, Japan [17]. The immature seed endosperm was collected from seeds extracted from the lotus seedpod in their post-pollination late immature stage. At the point of collection, the seeds were approximately $1.3 \mathrm{~cm}$ long, and the external husk was still green and soft. The seeds were washed and stored whole at $-80{ }^{\circ} \mathrm{C}$ until tissue extraction. The seeds were cut open and the soft and white core was removed whole and then cut across its length. The translucent sheet around the core, any discernible embryo tissue, as well as the 
central portion of the core immediately around the embryo was removed. The remaining soft endosperm fragments were ground under liquid nitrogen and the resulting powder was stored in sterile BD Falcon tubes at $-80{ }^{\circ} \mathrm{C}$ until extraction of protein. For embryo tissue sample preparation, the mature seeds (stored at room temperature) were cracked open in a clean environment and the endosperm and embryo portions were cleanly separated and stored in sterile BD Falcon tubes at $-80{ }^{\circ} \mathrm{C}$. The embryo fragments were ground into a fine powder in liquid nitrogen, with a pre-chilled mortar and pestle. Resulting powder was stored in sterile $2.0 \mathrm{~mL}$ microfuge tubes at $-80{ }^{\circ} \mathrm{C}$ until further analysis.

\subsection{Extraction of the Lotus Seed Immature Endosperm and Embryo Proteins}

Proteins were extracted from the powdered samples using the Tris-buffered saline (TBS) extraction method described in a previous study [17]. Briefly, a 3:1 mixture of TBS-20 buffer [10 mM Tris-HCl,

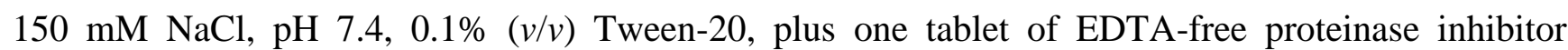
(cOmplete Mini, Roche) per $50 \mathrm{~mL}$ ] and SDS (sodium dodecyl sulfate) reducing buffer [62 $\mathrm{mM}$ Tris $(\mathrm{pH}$ 6.8), 10\% ( $v / v)$ glycerol, 2.5\% (w/v) SDS, 5\% (v/v) 2-mercaptoethanol] was used to extract the powdered samples at $2 \mathrm{~mL} / 100 \mathrm{mg}$. The sample/buffer mixtures were also subjected to several $30 \mathrm{~s}$ ultrasonic bath cycles and at $95{ }^{\circ} \mathrm{C}$ heating for $5 \mathrm{~min}$ to help extraction. The extract was separated by centrifugation, and its proteins precipitated and purified using the ProteoExtract kit (Calbiochem). The dry protein pellets obtained were either resolubilized in LB-TT (7 M urea, $2 \mathrm{M}$ thiourea, 4\% $(w / v)$ CHAPS, $18 \mathrm{mM}$ Tris-HCl (pH 8.0), $14 \mathrm{mM}$ Trizma base, $0.2 \%(v / v)$ Triton X-100 and $50 \mathrm{mM}$ dithiothreitol) for immediate use or stored at $-80^{\circ} \mathrm{C}$. Prior to use, protein content of the resolubilized extracts was measured by Bradford assay [18].

\subsection{Extraction of the Lotus Seed Immature Endosperm and Embryo Proteins}

Protein samples from both tissues were subjected to 1-DGE (SDS-PAGE, 12.5\%), both for visualization of protein profiles (Figure 2) using Coomassie Brilliant Blue [19] staining, and prior to analysis by 1DGE-MS.

The 1DGE-MS analyses followed the same methodology as with the previous lotus seed analyses [17]. The extracts were initially separated using SDS-PAGE. The resulting vertical protein lanes were sliced into eight pieces of equal length (regardless of apparent protein concentration) giving fraction $1:<120 \mathrm{kDa}$, fraction 2: $120-60 \mathrm{kDa}$, fraction 3: 60-40 kDa, fraction 4: 40-30 kDa, fraction 5: 30-22 kDa, fraction 6: 22-17 kDa, fraction 7: 17-14 kDa, and fraction 8: 14-10 kDa. Each fraction was digested with $1 \mu \mathrm{g}$ of trypsin at $37{ }^{\circ} \mathrm{C}$ for $16 \mathrm{~h}$ [17-20]. Digested peptides were recovered twice with $20 \mu \mathrm{L}$ of $5 \%(v / v)$ formic acid in 50\% $(v / v)$ acetonitrile. Extracted peptides were combined and then evaporated in a vacuum concentrator until liquid was dry. Dried peptides were dissolved into $20 \mu \mathrm{L}$ of $5 \%$ acetonitrile/ $0.1 \%$ formic acid and then filtrated by the Ultrafree-MC Centrifugal Filters (Millipore, PVDF $0.45 \mu \mathrm{m}$, Darmstadt, Germany). Liquid chromatography-tandem mass spectrometry (MS/MS) analysis was performed using the LTQ-Orbitrap XL-HTC-PAL system (Thermo, Waltham, MA, USA). Trypsin digests were loaded on the column (100 $\mu \mathrm{m}$ internal diameter, $15 \mathrm{~cm}$ length, L-Column, CERI) using the Paradigm MS4 HPLC pump (Michrom BioResources, Auburn, AL, USA) and HTC-PAL Autosampler (CTC Analytics, Zwingen, Switzerland), and were eluted by a gradient of 5\%-45\% ( $v / v)$ acetonitrile in $0.1 \%(v / v)$ formic acid for $26 \mathrm{~min}$. The eluted peptides were introduced directly into an 
LTQ-Orbitrap with a flow rate of $500 \mathrm{~nL} / \mathrm{min}$, and a spray voltage of $2.0 \mathrm{kV}$. The range of MS scan was $m / z$ 450-1500. The top three peaks were subjected to MS/MS analysis. MS/MS spectra were analyzed by Mascot server (version 2.4.1, Matrix Science, Boston, MA, USA) in house (http://www.matrixscience.com/) and compared against proteins registered in the SwissProt (SwissProt_2012_03) database (total sequences: 428650; sequences after taxonomy filter (Viridiplantae): 27008; date: 26 July 2013). The Mascot search parameters were set as follows: threshold of the ion score cutoff, 0.05 , peptide tolerance, $10 \mathrm{ppm}, \mathrm{MS} / \mathrm{MS}$ tolerance, $0.5 \mathrm{Da}$, and peptide charge, $2+$ or $3+$. The search was also set to allow one missed cleavage by trypsin, a carboxymethylation modification of Cys residues, and a variable oxidation modification of Met residues. Gene ontology analysis on the data was performed using the Uniprot (www.uniprot.org) and the EMBL-EBI (www.ebi.ac.uk) databases.
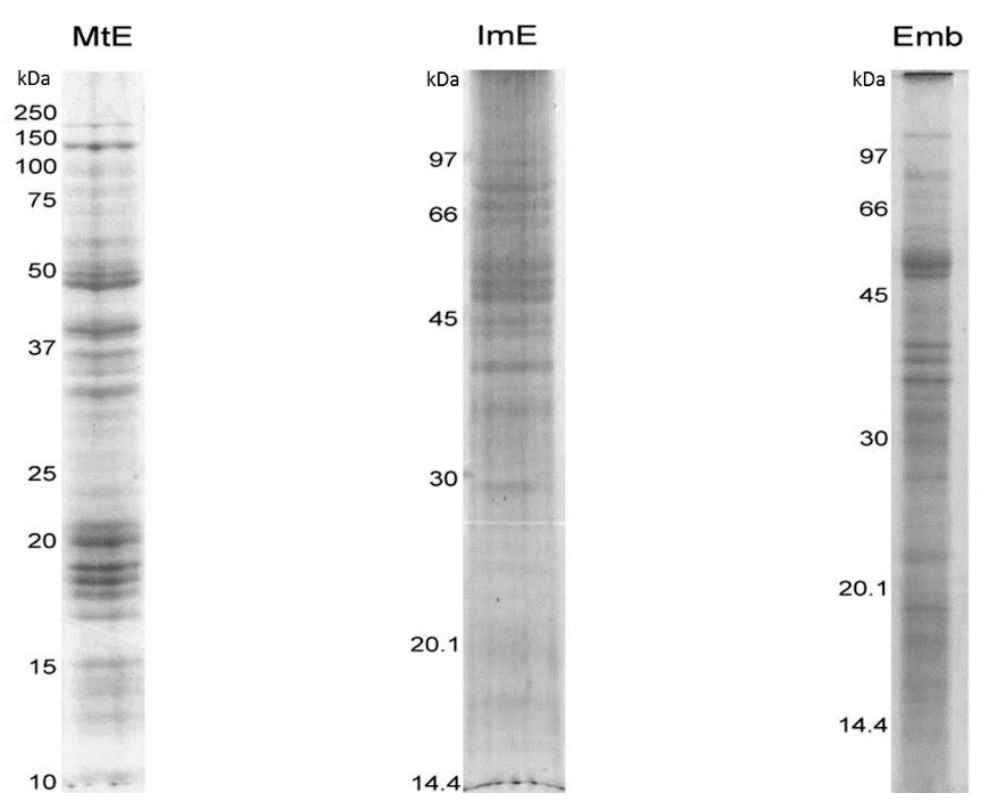

Figure 2. 1D SDS-PAGE of protein extracts from lotus seed mature endosperm (MtE), immature endosperm (ImE), and embryo (Emb). SDS-PAGE, 12.5\%; Coomassie brilliant blue stained. Molecular weight markers are shown on left-hand side of each gel image.

\section{Results and Discussion}

\subsection{Protein Content of the Immature Endosperm and Embryo Tissues}

Protein extracts from the lotus immature seed endosperm presented very low protein yield ( $\mathrm{ca} .1 .5 \%$ in the TBS method), requiring larger amounts of tissue to be extracted in order to obtain a suitable amount of protein. The reason for low protein yield lies in the high water content of the immature seed compared to its mature form. The lotus seed embryo showed a similar total protein yield to the endosperm extract [17] when extracted by the TBS/clean-up method (ca. 9\%, compared to $c a .11 \%$ for the mature endosperm).

A comparison of the of the 1-D band profile on the SDS-PAGE of the embryo extract with the endosperm one showed many similarities, but also some noticeable differences, such as an absence of 
strongly stained bands at $c a .20 \mathrm{kDa}$ and $40 \mathrm{kDa}$, and more numerous bands at low-molecular weights, under 30 and $20 \mathrm{kDa}$ (see above, Figure 2). In the case of the immature endosperm, the 1-D profile is more similar to the mature endosperm than the embryo, but still was found to be different from both tissues profiles. Compared with the mature endosperm extract, the immature endosperm extract most notably does not present a high amount of protein bands around the $20 \mathrm{kDa}$ range. The cluster of bands around $50 \mathrm{kDa}$ is similar to that in both the endosperm and embryo, and the immature endosperms profile of bands in the $60-90 \mathrm{kDa}$ range seems more similar to the mature endosperm than the embryo.

\subsection{Lotus Immature Endosperm Proteins Identified by 1-DGE and MS/MS Analyses}

The 1-DGE separation (SDS-PAGE) of proteins in an extract, followed by MS/MS analysis is part of the so-called "bottom-up" approach to proteomics, a methodology in which proteins are proteolytically digested into peptides prior to mass spectrometric analysis, and the ensuing peptide masses and sequences are used to identify corresponding proteins. This simple approach is a useful method for performing large-scale analyses of complex samples [21]. For the sample consisting of a purified extract of lotus immature endosperm proteins, after separation by SDS-PAGE, the sample was divided into eight fractions, analyzed by LC-MS/MS, and matched against a green plant database, as detailed in the Experimental Section. Results revealed more than 500 protein matches with at least two confirmed peptide fragment matches were identified amongst all fractions, and from these 333 unique protein matches were identified. Different database matches that were likely to refer to the same protein in the sample, such as two or more matches for the same protein but from different database organisms, were grouped together based on taxonomical proximity and similarity of identified peptide sequences. Finally, 122 non-redundant (nr) protein matches were listed, along with the number of repeated matches found for each one (Table 1), with the protein match listed being the one with the highest score amongst its group of similar proteins.

\subsection{Lotus Embryo Proteins Identified by 1-DGE and MS/MS Analyses}

The 1-DGE-MS analysis of the lotus embryo protein extract was performed following the same methodology, green plant database, and same parameters as for the immature endosperm extract. For the sample consisting of a purified extract of lotus embryo proteins, after separation by SDS-PAGE, the sample was divided into eight fractions, analyzed by LC-MS/MS, and matched against a green plant database, as above. From the initial results, 500+ protein matches with at least two confirmed peptide fragment matches were identified. After removing duplicate results from different gel fractions, there were 373 unique protein matches remaining. After grouping results likely to be the same protein in the sample, based on protein taxonomy and similarity of identified peptide sequences, $141 \mathrm{nr}$ protein matches were listed (Table 2). 
Table 1. List of top-scored non-redundant (nr) protein matches of the lotus immature endosperm 1-D shotgun mass spectroscopy results, as matched to Green Plant proteome database (SwissProt 57.0, http://www.uniprot.org/statistics/UniProtKB\%2015).

\begin{tabular}{|c|c|c|c|c|c|c|c|c|}
\hline Fractions ${ }^{1}$ & Protein Accession & Protein Description & Similar $^{2}$ & Score $^{3}$ & $\begin{array}{l}\text { Cover } \\
(\%)\end{array}$ & PEPTIDE Sequences & $\begin{array}{l}\text { Sig. Peptide } \\
\text { Number }\end{array}$ & $\begin{array}{l}\text { Func. } \\
\text { Cat. }^{4}\end{array}$ \\
\hline $6,5,8,(7,4,3,1)$ & ENO1_HEVBR & Enolase $1 \mathrm{OS}=$ Hevea brasiliensis & 11 & 1471 & 43.4 & $\begin{array}{l}\text { TAIAK, YNQLLR, LTSEIGEK, ACNALLLK, DGGSDYLGK, AGWGVMASHR, } \\
\text { EKACNALLLK, MGAEVYHHLK, RAGWGVMASHR, LGANAILAVSLAVCK, } \\
\text { VQIVGDDLLVTNPK, AAVPSGASTGIYEALELR, LAMQEFMILPVGASSFK, } \\
\text { SGETEDTFIADLSVGLATGQIK, YGQDATNVGDEGGFAPNIQENK, } \\
\text { KYGQDATNVGDEGGFAPNIQENK, YGQDATNVGDEGGFAPNIQENKEGLELLK }\end{array}$ & 17 & II \\
\hline $7,8,6,5,1,4,2$ & G3PC_ANTMA & $\begin{array}{l}\text { Glyceraldehyde-3-phosphate } \\
\text { dehydrogenase, cytosolic OS = Antirrhinum } \\
\text { majus }\end{array}$ & 23 & 1242 & 43.6 & $\begin{array}{l}\text { AAAHLK, KATYEQIK, AAIKEESEGK, AGIALNDNFVK, DAPMFVVGVNEK, } \\
\text { AASFNIIPSSTGAAK, VPTVDVSVVDLTVR, DAPMFVVGVNEKEYK, } \\
\text { VPTVDVSVVDLTVRLEK, FGIVEGLMTTVHSITATQK, } \\
\text { GILGYTEDDVVSTDFVGDSR, LTGMSFRVPTVDVSVVDLTVR, } \\
\text { LKGILGYTEDDVVSTDFVGDSR, VINDRFGIVEGLMTTVHSITATQK }\end{array}$ & 14 & II \\
\hline $4,8,6,7,5$ & HSP7D_ARATH & $\begin{array}{l}\text { Heat shock } 70 \mathrm{kDa} \text { protein } 4 \\
\mathrm{OS}=\text { Arabidopsis thaliana }\end{array}$ & 10 & 625 & 23.8 & $\begin{array}{l}\text { IEEVD, LSKEEIEK, ITITNDKGR, DAGVISGLNVMR, NALENYAYNMR, } \\
\text { MVNHFVQEFKR, TTPSYVAFTDSER, IINEPTAAAIAYGLDK, } \\
\text { ATAGDTHLGGEDFDNR, NAVVTVPAYFNDSQR, IINEPTAAAIAYGLDKK, } \\
\text { EQIFSTYSDNQPGVLIQVYEGER }\end{array}$ & 12 & IX \\
\hline 4 & HSP7E_SPIOL & $\begin{array}{l}\text { Chloroplast envelope membrane } 70 \mathrm{kDa} \\
\text { heat shock-related protein OS = Spinacia } \\
\text { oleracea }\end{array}$ & 1 & 580 & 21.7 & $\begin{array}{l}\text { LSKEEIEK, DAGVISGLNVMR, EIAEAYLGSTVK, NALENYAYNMR, } \\
\text { TTPSYVAFTDSER, IINEPTAAAIAYGLDK, ATAGDTHLGGEDFDNR, } \\
\text { NAVVTVPAYFNDSQR, IINEPTAAAIAYGLDKK, } \\
\text { EQVFSTYSDNQPGVLIQVYEGER }\end{array}$ & 10 & IX \\
\hline 4 & BIP4_TOBAC & $\begin{array}{l}\text { Luminal-binding protein } 4 \mathrm{OS}=\text { Nicotiana } \\
\text { tabacum }\end{array}$ & 5 & 542 & 21.6 & $\begin{array}{l}\text { VQQLLK, NTVIPTKK, IMEYFIK, LSQEEIER, ITITNDKGR, DYFDGKEPNK, } \\
\text { FEELNNDLFR, EAEEFAEEDKK, IVNKDGKPYIQVK, ARFEELNNDLFR, } \\
\text { NGHVEIIANDQGNR, IINEPTAAAIAYGLDK, IINEPTAAAIAYGLDKK, } \\
\text { IKDAVVTVPAYFNDAQR }\end{array}$ & 14 & IX \\
\hline
\end{tabular}


Table 1. Cont.

\begin{tabular}{|c|c|c|c|c|c|c|c|c|}
\hline Fractions ${ }^{1}$ & Protein Accession & Protein Description & Similar $^{2}$ & Score $^{3}$ & Cover $(\%)$ & PEPTIDE Sequences & $\begin{array}{l}\text { Sig. Peptide } \\
\text { Number }\end{array}$ & $\begin{array}{l}\text { Func. } \\
\text { Cat. }^{4} \\
\end{array}$ \\
\hline $4,5,6,7,8$ & METE_ARATH & $\begin{array}{l}\text { 5-methyltetrahydropteroyltriglutamate- } \\
\text { homocysteine methyltransferase } \\
\text { OS = Arabidopsis thaliana }\end{array}$ & 4 & 516 & 19.2 & $\begin{array}{l}\text { AAAALK, VVEVNALAK, SWLAFAAQK, AVNEYKEAK, } \\
\text { YLFAGVVDGR, SDEKLLSVFR, FALESFWDGK, } \\
\text { GNASVPAMEMTK, YGAGIGPGVYDIHSPR, } \\
\text { GMLTGPVTILNWSFVR }\end{array}$ & 10 & I \\
\hline $6,1,5,(7,8,3,2,4)$ & EF1A_TOBAC & $\begin{array}{l}\text { Elongation factor 1-alpha } \\
\text { OS = Nicotiana tabacum }\end{array}$ & 8 & 484 & 34.7 & $\begin{array}{l}\text { YDEIVK, GFVASNSK, QTVAVGVIK, EVSSYLKK, LPLQDVYK, } \\
\text { ARYDEIVK, IGGIGTVPVGR, STNLDWYK, STTTGHLIYK, } \\
\text { EHALLAFTLGVK, GFVASNSKDDPAK, YYCTVIDAPGHR, } \\
\text { MIPTKPMVVETFSEYPPLGR, } \\
\text { NMITGTSQADCAVLIIDSTTGGFEAGISK }\end{array}$ & 14 & $\mathrm{~V}$ \\
\hline 4 & HSP7L_ARATH & $\begin{array}{l}\text { Heat shock } 70 \mathrm{kDa} \text { protein } 12 \\
\mathrm{OS}=\text { Arabidopsis thaliana }\end{array}$ & 1 & 479 & 16.5 & $\begin{array}{l}\text { VQQLLK, NTVIPTKK, IMEYFIK, FDLTGVPPAPR, FEELNNDLFR, } \\
\text { EAEEFAEEDKK, ARFEELNNDLFR, NGHVEIIANDQGNR, } \\
\text { IINEPTAAAIAYGLDK, IINEPTAAAIAYGLDKK, } \\
\text { IKDAVVTVPAYFNDAQR }\end{array}$ & 11 & IX \\
\hline $4,8,6$ & HSP7N_ARATH & $\begin{array}{l}\text { Heat shock } 70 \mathrm{kDa} \text { protein } 18 \\
\mathrm{OS}=\text { Arabidopsis thaliana }\end{array}$ & 1 & 474 & 18.5 & $\begin{array}{l}\text { ITITNDKGR, EIAEAYLGSSIK, MVNHFVQEFKR, } \\
\text { TTPSYVAFTDSER, IINEPTAAAIAYGLDK, } \\
\text { ATAGDTHLGGEDFDNR, NAVVTVPAYFNDSQR, } \\
\text { IINEPTAAAIAYGLDKK }\end{array}$ & 8 & IX \\
\hline 7 & MDHM_CITLA & $\begin{array}{l}\text { Malate dehydrogenase, mitochondrial } \\
\text { OS = Citrullus lanatus }\end{array}$ & 5 & 459 & 18.2 & $\begin{array}{l}\text { TFYAGK, LFGVTTLDVVR, TQDGGTEVVEAK, DDLFNINAGIVK, } \\
\text { KLFGVTTLDVVR, RTQDGGTEVVEAK, } \\
\text { VAVLGAAGGIGQPLALLMK, KVAVLGAAGGIGQPLALLMK }\end{array}$ & 8 & II \\
\hline 4,5 & HSP80_SOLLC & $\begin{array}{l}\text { Heat shock cognate protein } 80 \\
\text { OS = Solanum lycopersicum }\end{array}$ & 1 & 427 & 20.9 & $\begin{array}{l}\text { AVENSPFLEK, LGIHEDSQNR, ADLVNNLGTIAR, KAVENSPFLEK, } \\
\text { HFSVEGQLEFK, GIVDSEDLPLNISR, SLTNDWEEHLAVK, } \\
\text { SGDEMTSLKDYVTR, KPEEITKEEYAAFYK, } \\
\text { MKEGQNDIYYITGESK }\end{array}$ & 10 & IX \\
\hline
\end{tabular}


Table 1. Cont.

\begin{tabular}{|c|c|c|c|c|c|c|c|c|}
\hline Fractions ${ }^{1}$ & Protein Accession & Protein Description & Similar $^{2}$ & Score $^{3}$ & Cover $(\%)$ & PEPTIDE Sequences & $\begin{array}{l}\text { Sig. Peptide } \\
\text { Number }\end{array}$ & $\begin{array}{l}\text { Func. } \\
\text { Cat. }{ }^{4}\end{array}$ \\
\hline 5 & CH62_MAIZE & $\begin{array}{l}\text { Chaperonin CPN60-2, } \\
\text { mitochondrial OS = Zea mays }\end{array}$ & 6 & 422 & 23.3 & $\begin{array}{l}\text { VTDALNATK, GVEELADAVK, IGGASEAEVGEK, } \\
\text { SVAAGMNAMDLR, IGGASEAEVGEKK, NVVIEQSFGAPK, } \\
\text { AAVEEGIVPGGGVALLYASK, TPVHTIASNAGVEGAVVVGK, } \\
\text { QRPLLIVAEDVESEALGTLIINK }\end{array}$ & 9 & IX \\
\hline $7,8,6,1$ & ACT_GOSHI & Actin OS = Gossypium hirsutum & 19 & 414 & 32.6 & $\begin{array}{l}\text { AGFAGDDAPR, GYSFTTTAER, EITALAPSSMK, } \\
\text { DAYVGDEAQSK, AVFPSIVGRPR, DAYVGDEAQSKR, } \\
\text { SYELPDGQVITIGAER, VAPEEHPVLLTEAPLNPK, } \\
\text { TTGIVLDSGDGVSHTVPIYEGYALPHAILR }\end{array}$ & 9 & VII \\
\hline $5,8,7$ & ENO2_ARATH & $\begin{array}{l}\text { Bifunctional enolase } \\
\text { 2/transcriptional activator } \\
\text { OS = Arabidopsis thaliana }\end{array}$ & 1 & 411 & 34.5 & $\begin{array}{l}\text { YNQLLR, DGGSDYLGK, ISGDALKDLYK, } \\
\text { LGANAILAVSLAVCK, VNQIGSVTESIEAVK, } \\
\text { TYDLNFKEENNNGSQK, SGETEDTFIADLAVGLSTGQIK, } \\
\text { YGQDATNVGDEGGFAPNIQENK, } \\
\text { YGQDATNVGDEGGFAPNIQENKEGLELLK }\end{array}$ & 9 & IV \\
\hline $4,5,6$ & HSP83_IPONI & $\begin{array}{l}\text { Heat shock protein } 83 \\
\text { OS = Ipomoea nil }\end{array}$ & 1 & 405 & 23 & $\begin{array}{l}\text { VIVTTK, VVVSDR, AILFVPK, DVDGEQLGR, APFDLFDTR, } \\
\text { AVENSPFLER, LGIHEDSQNR, LDAQPELFIR, RAPFDLFDTR, } \\
\text { ADLVNNLGTIAR, ELISNASDALDK, HFSVEGQLEFK, } \\
\text { GVVDSDDLPLNISR, ELISNASDALDKIR, ITLFLKEDQLEYLEER }\end{array}$ & 14 & IX \\
\hline $7,6,1,2$ & ADH1_SOLTU & $\begin{array}{l}\text { Alcohol dehydrogenase } 1 \\
\text { OS = Solanum tuberosum }\end{array}$ & 7 & 390 & 23.7 & $\begin{array}{l}\text { ELELEK, SDIPSVVEK, FGVTEFVNPK, GTFFGNYKPR, } \\
\text { THPMNLLNER, KFGVTEFVNPK, YMNKELELEK, } \\
\text { TLKGTFFGNYKPR, GSSVAIFGLGAVGLAAAEGAR }\end{array}$ & 9 & II \\
\hline $4,5,7,8$ & ENPL_CATRO & $\begin{array}{l}\text { Endoplasmin homolog } \\
\text { OS = Catharanthus roseus }\end{array}$ & 3 & 387 & 10.5 & $\begin{array}{l}\text { FWNEFGK, ESFKELTK, YGWSSNMER, ELISNASDALDK, } \\
\text { IMQSQTLSDASK, GLVDSDTLPLNVSR, ELISNASDALDKIR, } \\
\text { VFISDEFDELLPK, RVFISDEFDELLPK }\end{array}$ & 9 & IX \\
\hline
\end{tabular}


Table 1. Cont.

\begin{tabular}{|c|c|c|c|c|c|c|c|c|}
\hline Fractions ${ }^{1}$ & $\begin{array}{l}\text { Protein } \\
\text { Accession }\end{array}$ & Protein Description & Similar $^{2}$ & Score $^{3}$ & Cover $(\%)$ & PEPTIDE Sequences & $\begin{array}{l}\text { Sig. Peptide } \\
\text { Number }\end{array}$ & $\begin{array}{l}\text { Func. } \\
\text { Cat. }^{4}\end{array}$ \\
\hline $7,(8,6)$ & RBL_MAIZE & $\begin{array}{l}\text { Ribulose bisphosphate } \\
\text { carboxylase large chain } \\
\text { OS = Zea mays }\end{array}$ & 52 & 382 & 27.5 & $\begin{array}{l}\text { AMHAVIDR, AQAETGEIK, DTDILAAFR, DDFIEKDR, } \\
\text { VALEACVQAR, EITLGFVDLLR, LTYYTPEYETK, } \\
\text { MSGGDHIHSGTVVGK, YGRPLLGCTIKPK, } \\
\text { GGLDFTKDDENVNSQPFMR }\end{array}$ & 10 & I \\
\hline 6 & SAHH_MEDSA & $\begin{array}{l}\text { Adenosylhomocysteinase } \\
\text { OS }=\text { Medicago sativa }\end{array}$ & 3 & 369 & 15.1 & $\begin{array}{l}\text { ATDVMIAGK, HSLPDGLMR, ITIKPQTDR, TEFGPSQPFK, } \\
\text { VAVVCGYGDVGK, SKFDNLYGCR, IVGVSEETTTGVK, } \\
\text { IVGVSEETTTGVKR }\end{array}$ & 8 & I \\
\hline $4,(5,6)$ & HSP82_ORYSJ & $\begin{array}{l}\text { Heat shock protein } 81-2 \\
\text { OS }=\text { Oryza sativa subsp. } \\
\text { Japonica }\end{array}$ & 2 & 368 & 21.5 & $\begin{array}{l}\text { VVVSDR, IAELLR, AILFVPK, APFDLFDTR, AVENSPFLEK, } \\
\text { RAPFDLFDTR, KAVENSPFLEK, SDLVNNLGTIAR, } \\
\text { HFSVEGQLEFK, GIVDSEDLPLNISR, SLTNDWEEHLAVK, } \\
\text { HSEFISYPISLWTEK, KPEEITKEEYAAFYK }\end{array}$ & 12 & IX \\
\hline $4,6,7$ & HSP70_DAUCA & $\begin{array}{l}\text { Heat shock } 70 \mathrm{kDa} \\
\text { protein } \mathrm{OS}=\text { Daucus } \\
\text { carota }\end{array}$ & 1 & 335 & 15.7 & $\begin{array}{l}\text { IEEVD, NALENYAYNMR, NQVAMNPSNTVFDAK, } \\
\text { NQVAMNPSNTVFDAKR, } \\
\text { SINPDEAVAYGAAVQAAILSGEGNER, } \\
\text { EQIFSTYSDNQPGVLIQVYEGER }\end{array}$ & 6 & IX \\
\hline 5 & CPNA1_ARATH & $\begin{array}{l}\text { Chaperonin } 60 \text { subunit } \\
\text { alpha } 1 \text {, chloroplastic OS } \\
=\text { Arabidopsis thaliana }\end{array}$ & 1 & 331 & 16.4 & $\begin{array}{l}\text { KVTISK, VVNDGVTIAR, NVVLDEFGSPK, VGAATETELEDR, } \\
\text { GYISPQFVTNPEK, TNDSAGDGTTTASILAR }\end{array}$ & 6 & IX \\
\hline 4,5 & HSP82_MAIZE & $\begin{array}{l}\text { Heat shock protein } 82 \\
\text { OS = Zea mays }\end{array}$ & 2 & 297 & 14.4 & $\begin{array}{l}\text { APFDLFDTR, AVENSPFLER, LGIHEDSQNR, RAPFDLFDTR, } \\
\text { SDLVNNLGTIAR, ELISNASDALDK, HFSVEGQLEFK, } \\
\text { GVVDSDDLPLNISR, ELISNASDALDKIR }\end{array}$ & 9 & IX \\
\hline
\end{tabular}


Table 1. Cont.

\begin{tabular}{|c|c|c|c|c|c|c|c|c|}
\hline Fractions ${ }^{1}$ & $\begin{array}{l}\text { Protein } \\
\text { Accession }\end{array}$ & Protein Description & Similar $^{2}$ & Score $^{3}$ & Cover $(\%)$ & PEPTIDE Sequences & $\begin{array}{l}\text { Sig. Peptide } \\
\text { Number }\end{array}$ & $\begin{array}{l}\text { Func. } \\
\text { Cat. }^{4}\end{array}$ \\
\hline 8,7 & ALF_CICAR & $\begin{array}{l}\text { Fructose-bisphosphate aldolase, } \\
\text { cytoplasmic isozyme OS }=\text { Cicer } \\
\text { arietinum }\end{array}$ & 2 & 289 & 14.2 & $\begin{array}{l}\text { ANSEATLGTYK, GILAADESTGTIGK, GILAADESTGTIGKR, } \\
\text { YHDELIANAAYIGTPGK }\end{array}$ & 4 & II \\
\hline $4,(3,5)$ & CD48A_ARATH & $\begin{array}{l}\text { Cell division control protein } 48 \\
\text { homolog A OS = Arabidopsis thaliana }\end{array}$ & 3 & 285 & 14 & $\begin{array}{l}\text { TLLAK, KGDLFLVR, ELVELPLR, LAEDVDLER, } \\
\text { LAGESESNLR, GILLYGPPGSGK, IVSQLLTLMDGLK, } \\
\text { ELVELPLRHPQLFK, NAPSIIFIDEIDSIAPK }\end{array}$ & 9 & III/IV \\
\hline $7,8,6,1$ & PGKH_TOBAC & $\begin{array}{l}\text { Phosphoglycerate kinase, chloroplastic } \\
\text { OS = Nicotiana tabacum }\end{array}$ & 6 & 284 & 15.4 & $\begin{array}{l}\text { AAVPTIK, AHASTEGVTK, FAVGTEAIAK, VILSSHLGRPK, } \\
\text { GVTTIIGGGDSVAAVEK, LASLADLYVNDAFGTAHR, } \\
\text { KLASLADLYVNDAFGTAHR }\end{array}$ & 7 & II \\
\hline $5,(4)$ & PGMC_POPTN & $\begin{array}{l}\text { Phosphoglucomutase, cytoplasmic } \mathrm{OS}= \\
\text { Populus tremula }\end{array}$ & 1 & 281 & 12.2 & $\begin{array}{l}\text { YLFEDGSR, FFEVPTGWK, LSGTGSEGATIR, } \\
\text { SMPTSAALDVVAK, YDYENVDAGAAK, } \\
\text { VETTPFGDQKPGTSGLR }\end{array}$ & 6 & II \\
\hline $4,(5)$ & HS903_ARATH & $\begin{array}{l}\text { Heat shock protein } 90-3 \\
\text { OS }=\text { Arabidopsis thaliana }\end{array}$ & 3 & 269 & 20.2 & $\begin{array}{l}\text { IAELLR, AILFVPK, AVENSPFLEK, LGIHEDSQNR, } \\
\text { ADLVNNLGTIAR, KAVENSPFLEK, HFSVEGQLEFK, } \\
\text { GIVDSEDLPLNISR, HSEFISYPISLWIEK }\end{array}$ & 9 & IX \\
\hline 5,6 & PMG2_ARATH & $\begin{array}{l}\text { Probable 2,3-bisphosphoglycerate- } \\
\text { independent phosphoglycerate mutase } 2 \\
\text { OS = Arabidopsis thaliana }\end{array}$ & 1 & 257 & 13.6 & $\begin{array}{l}\text { VHILTDGR, ARDAILSGK, LVDLALASGK, TFACSETVK, } \\
\text { MKALEIAEK, GWDAQVLGEAPHK, RGWDAQVLGEAPHK, } \\
\text { AVGPIVDGDAVVTFNFR }\end{array}$ & 8 & II \\
\hline
\end{tabular}


Table 1. Cont.

\begin{tabular}{|c|c|c|c|c|c|c|c|c|}
\hline Fractions $^{1}$ & $\begin{array}{l}\text { Protein } \\
\text { Accession }\end{array}$ & Protein Description & Similar $^{2}$ & Score $^{3}$ & Cover $(\%)$ & PEPTIDE Sequences & $\begin{array}{l}\text { Sig. Peptide } \\
\text { Number }\end{array}$ & $\begin{array}{l}\text { Func. } \\
\text { Cat. }^{4}\end{array}$ \\
\hline 5,6 & PMG1_ARATH & $\begin{array}{l}\text { 2,3-bisphosphoglycerate- } \\
\text { independent phosphoglycerate } \\
\text { mutase } 1 \mathrm{OS}=\text { Arabidopsis } \\
\text { thaliana }\end{array}$ & 5 & 224 & 10.2 & $\begin{array}{l}\text { VHILTDGR, ARDAILSGK, LDQLQLLIK, GWDAQVLGEAPHK, } \\
\text { RGWDAQVLGEAPHK, AVGPIVDGDAVVTFNFR }\end{array}$ & 6 & II \\
\hline 5 & SSG1_HORVU & $\begin{array}{l}\text { Granule-bound starch synthase } 1 \text {, } \\
\text { chloroplastic/amyloplastic } \\
\text { OS = Hordeum vulgare }\end{array}$ & 5 & 214 & 7.5 & $\begin{array}{l}\text { FFHCYK, EALQAEVGLPVDR, FSLLCQAALEAPR, } \\
\text { VAFCIHNISYQGR }\end{array}$ & 4 & I \\
\hline 6 & RL4_PRUAR & $\begin{array}{l}\text { 60S ribosomal protein } \mathrm{L} 4 \\
\mathrm{OS}=\text { Prunus armeniaca }\end{array}$ & 3 & 200 & 20.8 & $\begin{array}{l}\text { AGQGAFGNMCR,AGHQTSAESWGTGR, } \\
\text { YAVVSAIAASAVPSLVLAR, AWYQTMISDSDYTEFDNFTK }\end{array}$ & 4 & $\mathrm{~V}$ \\
\hline 8 & H2B_GOSHI & $\begin{array}{l}\text { Histone } \mathrm{H} 2 \mathrm{~B} \text { OS = Gossypium } \\
\text { hirsutum }\end{array}$ & 5 & 200 & 49 & IYIFK, LVLPGELAK, AMGIMNSFINDIFEK & 3 & VII \\
\hline 5 & RUBA_RICCO & $\begin{array}{l}\text { RuBisCO large subunit-binding } \\
\text { protein subunit alpha (Fragment) } \\
\text { OS = Ricinus communis }\end{array}$ & 2 & 200 & 16 & $\begin{array}{l}\text { NVVLDEFGSPK VGAATETELEDR, GYISPQFVTNPEK, } \\
\text { LGLLSVTSGANPVSIK }\end{array}$ & 4 & I \\
\hline 8 & H2B1_MEDTR & $\begin{array}{l}\text { Probable histone } \mathrm{H} 2 \mathrm{~B} .1 \\
\mathrm{OS}=\text { Medicago truncatula }\end{array}$ & 2 & 199 & 45.3 & IYIFK, LVLPGELAK, AMGIMNSFINDIFEK & 3 & VII \\
\hline 8 & RL182_ARATH & $\begin{array}{l}\text { 60S ribosomal protein } \mathrm{L} 18-2 \\
\mathrm{OS}=\text { Arabidopsis thaliana }\end{array}$ & 1 & 185 & 13.4 & APLGQNTVLLR, AGGECLTFDQLALR & 2 & V \\
\hline 5 & CALR_BERST & $\begin{array}{l}\text { Calreticulin OS = Berberis } \\
\text { stolonifera }\end{array}$ & 3 & 175 & 9.1 & $\begin{array}{l}\text { LAEETWGK, LLSGDVDQK, KLAEETWGK, TLVFQFSVK, } \\
\text { LLSGDVDQKK, YVGIELWQVK }\end{array}$ & 6 & $\mathrm{~V}$ \\
\hline 8 & 1433E_TOBAC & $\begin{array}{l}\text { 14-3-3-like protein E } \\
\text { OS = Nicotiana tabacum }\end{array}$ & 5 & 172 & 26.8 & $\begin{array}{l}\text { NVIGAR, NLLSVAYK, DSTLIMQLLR, TVDVEELTVEER, } \\
\text { IISSIEQKEESR, SAQDIALAELAPTHPIR }\end{array}$ & 6 & VIII \\
\hline
\end{tabular}


Table 1. Cont.

\begin{tabular}{|c|c|c|c|c|c|c|c|c|}
\hline Fractions ${ }^{1}$ & $\begin{array}{l}\text { Protein } \\
\text { Accession }\end{array}$ & Protein Description & Similar $^{2}$ & Score $^{3}$ & Cover $(\%)$ & PEPTIDE Sequences & $\begin{array}{l}\text { Sig. Peptide } \\
\text { Number }\end{array}$ & $\begin{array}{l}\text { Func. } \\
\text { Cat. }^{4}\end{array}$ \\
\hline 8 & H4_ARATH & Histone $\mathrm{H} 4 \mathrm{OS}=$ Arabidopsis thaliana & 1 & 160 & 45.6 & $\begin{array}{l}\text { TLYGFGG, IFLENVIR, DAVTYTEHAR, ISGLIYEETR, } \\
\text { DNIQGITKPAIR }\end{array}$ & 5 & VII \\
\hline $6,5,8$ & KPYC_SOYBN & $\begin{array}{l}\text { Pyruvate kinase, cytosolic isozyme } \\
\text { OS = Glycine } \max \end{array}$ & 2 & 157 & 9.2 & KGSDLVNVR, GDLGMEIPVEK, VENQEGVLNFDEILR & 3 & II \\
\hline 8 & RS6_ASPOF & $\begin{array}{l}\text { 40S ribosomal protein } \mathrm{S} 6 \\
\mathrm{OS}=\text { Asparagus officinalis }\end{array}$ & 2 & 155 & 11.6 & LVTPLTLQR, ISQEVSGDALGEEFK, ISQEVSGDALGEEFKGYVFK & 3 & $\mathrm{~V}$ \\
\hline 5 & TCPA_ARATH & $\begin{array}{l}\text { T-complex protein } 1 \text { subunit alpha } \\
\text { OS = Arabidopsis thaliana }\end{array}$ & 1 & 153 & 6.4 & YFVEAGAIAVR, VLVELAELQDR, NKIHPTSIISGYR & 3 & $\mathrm{~V}$ \\
\hline 1 & ADT1_GOSHI & $\begin{array}{l}\text { ADP,ATP carrier protein } 1 \text {, } \\
\text { mitochondrial OS = Gossypium } \\
\text { hirsutum }\end{array}$ & 1 & 143 & 5.7 & SSLDAFSQILK, LLIQNQDEMIK & 2 & VI \\
\hline 4 & HSP7S_SPIOL & $\begin{array}{l}\text { Stromal } 70 \mathrm{kDa} \text { heat shock-related } \\
\text { protein, chloroplastic (Fragment) } \\
\text { OS = Spinacia oleracea }\end{array}$ & 2 & 142 & 7.2 & QFAAEEISAQVLR, AVVTVPAYFNDSQR, IINEPTAASLAYGFEK & 3 & IX \\
\hline 7,8 & GCST_PEA & $\begin{array}{l}\text { Aminomethyltransferase, mitochondrial } \\
\text { OS = Pisum sativum }\end{array}$ & 2 & 140 & 14.7 & $\begin{array}{l}\text { LYFGEFR, GGAIDDSVITK, SLLALQGPLAAPVLQHLTK, } \\
\text { TGYTGEDGFEISVPSEHGVELAK }\end{array}$ & 4 & I \\
\hline 3,2 & HSP7O_ARATH & $\begin{array}{l}\text { Heat shock } 70 \mathrm{kDa} \text { protein } 14 \\
\mathrm{OS}=\text { Arabidopsis thaliana }\end{array}$ & 1 & 139 & 7.7 & $\begin{array}{l}\text { ILSHAFDR, AVLDAATIAGLHPLR, AVEKEFEMALQDR, } \\
\text { RAVLDAATIAGLHPLR }\end{array}$ & 4 & IX \\
\hline 4 & HSP7F_ARATH & $\begin{array}{l}\text { Heat shock } 70 \mathrm{kDa} \text { protein } 6 \text {, } \\
\text { chloroplastic } \mathrm{OS}=\text { Arabidopsis thaliana }\end{array}$ & 1 & 139 & 7.5 & $\begin{array}{l}\text { TTPSVVAYTK, } \\
\text { QFAAEEISAQVLR,QAVVNPENTFFSVK,LSFKDIDEVILVGGSTR }\end{array}$ & 4 & IX \\
\hline 8 & RS4_GOSHI & $\begin{array}{l}\text { 40S ribosomal protein } \mathrm{S} 4 \\
\mathrm{OS}=\text { Gossypium hirsutum }\end{array}$ & 2 & 135 & 20.6 & $\begin{array}{l}\text { LSIIEEAR, LGNVFTIGK, FDVGNVVMVTGGR, } \\
\text { LGGAFAPKPSSGPHK }\end{array}$ & 4 & V \\
\hline
\end{tabular}


Table 1. Cont.

\begin{tabular}{|c|c|c|c|c|c|c|c|c|}
\hline Fractions ${ }^{1}$ & $\begin{array}{l}\text { Protein } \\
\text { Accession }\end{array}$ & Protein Description & Similar $^{2}$ & Score $^{3}$ & Cover $(\%)$ & PEPTIDE Sequences & $\begin{array}{l}\text { Sig. Peptide } \\
\text { Number }\end{array}$ & $\begin{array}{l}\text { Func. } \\
\text { Cat. }{ }^{4}\end{array}$ \\
\hline 3,4 & CLPA_BRANA & $\begin{array}{l}\text { ATP-dependent Clp protease ATP- } \\
\text { binding subunit clpA homolog, } \\
\text { chloroplastic (Fragment) } \\
\text { OS = Brassica napus }\end{array}$ & 1 & 135 & 5.8 & VIGQDEAVK, TAIAEGLAQR,YRGEFEER, VLELSLEEAR & 4 & I \\
\hline $4,5,8$ & EF2_BETVU & $\begin{array}{l}\text { Elongation factor } 2 \mathrm{OS}=\text { Beta } \\
\text { vulgaris }\end{array}$ & 1 & 131 & 5.5 & $\begin{array}{l}\text { GGGQIIPTAR,EGALAEENMR,RVFYASQLTAKPR, } \\
\text { LWGENFFDPATKK }\end{array}$ & 4 & $\mathrm{~V}$ \\
\hline 8 & RL12_PRUAR & $\begin{array}{l}\text { 60S ribosomal protein } \mathrm{L} 12 \\
\mathrm{OS}=\text { Prunus armeniaca }\end{array}$ & 1 & 129 & 22.3 & VSVVPSAAALVIK, VTGGEVGAASSLAPK & 2 & $\mathrm{~V}$ \\
\hline $6,(7,8)$ & ATPBM_NICPL & $\begin{array}{l}\text { ATP synthase subunit beta, } \\
\text { mitochondrial OS = Nicotiana } \\
\text { plumbaginifolia }\end{array}$ & 4 & 129 & 12.5 & $\begin{array}{l}\text { VLNTGSPITVPVGR, TVLIMELINNVAK, } \\
\text { IPSAVGYQPTLATDLGGLQER }\end{array}$ & 3 & I \\
\hline $4,(7)$ & PHSH_SOLTU & $\begin{array}{l}\text { Alpha-glucan phosphorylase, } \mathrm{H} \\
\text { isozyme OS = Solanum tuberosum }\end{array}$ & 6 & 125 & 5.6 & $\begin{array}{l}\text { AFATYTNAK, } \\
\text { QLLNILGVIYR,HMEIIEEIDKR,TIAYTNHTVLPEALEK }\end{array}$ & 4 & II \\
\hline 6 & RL3_ORYSJ & $\begin{array}{l}\text { 60S ribosomal protein } \mathrm{L} 3 \\
\mathrm{OS}=\text { Oryza sativa subsp. Japonica }\end{array}$ & 2 & 124 & 6.9 & VIAHTQIR, HGSLGFLPR, GKGYEGVVTR & 3 & $\mathrm{~V}$ \\
\hline 8 & TPIS_MAIZE & $\begin{array}{l}\text { Triosephosphate isomerase, } \\
\text { cytosolic OS = Zea mays }\end{array}$ & 2 & 124 & 11.9 & FFVGGNWK, VAYALSQGLK, VIACVGETLEQR & 3 & VII \\
\hline 8 & LE194_HORVU & $\begin{array}{l}\text { Late embryogenesis abundant } \\
\text { protein B19.4 OS = Hordeum } \\
\text { vulgare }\end{array}$ & 1 & 121 & 9.2 & GGLSTMNESGGER, KGGLSTMNESGGER & 2 & IX \\
\hline $1,(2)$ & AVP_VIGRR & $\begin{array}{l}\text { Pyrophosphate-energized vacuolar } \\
\text { membrane proton pump } \\
\text { OS = Vigna radiata var. } \text { Radiata }\end{array}$ & 2 & 117 & 3.3 & AADVGADLVGK, YIEAGASEHAR, AADVGADLVGKVER & 3 & VI \\
\hline
\end{tabular}


Table 1. Cont.

\begin{tabular}{|c|c|c|c|c|c|c|c|c|}
\hline Fractions ${ }^{1}$ & $\begin{array}{l}\text { Protein } \\
\text { Accession }\end{array}$ & Protein Description & Similar $^{2}$ & Score $^{3}$ & Cover $(\%)$ & PEPTIDE Sequences & $\begin{array}{l}\text { Sig. Peptide } \\
\text { Number }\end{array}$ & $\begin{array}{l}\text { Func. } \\
\text { Cat. }^{4}\end{array}$ \\
\hline 8 & RL6_MESCR & $\begin{array}{l}\text { 60S ribosomal protein L6 OS = } \\
\text { Mesembryanthemum crystallinum }\end{array}$ & 1 & 115 & 10.7 & VDISGVNVEK, ASITPGTVLIILAGR & 2 & $\mathrm{~V}$ \\
\hline 5 & SSG1_ARATH & $\begin{array}{l}\text { Probable granule-bound starch } \\
\text { synthase } 1, \\
\text { chloroplastic/amyloplastic OS = } \\
\text { Arabidopsis thaliana }\end{array}$ & 1 & 115 & 3.9 & FFHCYK, YGTVPIVASTGGLVDTVK & 2 & I \\
\hline 8 & RL10_VITRI & $\begin{array}{l}60 \mathrm{~S} \text { ribosomal protein } \mathrm{L} 10 \mathrm{OS}= \\
\text { Vitis riparia }\end{array}$ & 1 & 114 & 10.5 & VSIGQVLLSVR, ENVSSEALEAAR & 2 & $\mathrm{~V}$ \\
\hline 8 & RS18_ARATH & $\begin{array}{l}\text { 40S ribosomal protein } \mathrm{S} 18 \mathrm{OS}= \\
\text { Arabidopsis thaliana }\end{array}$ & 1 & 111 & 21.7 & LRDDLER, VLNTNVDGK, IMFALTSIK, IPDWFLNR & 4 & $\mathrm{~V}$ \\
\hline 7 & AATM_LUPAN & $\begin{array}{l}\text { Aspartate aminotransferase P2, } \\
\text { mitochondrial (Fragment) } \\
\text { OS = Lupinus angustifolius }\end{array}$ & 1 & 111 & 6.8 & IADVIQEK, LNLGVGAYR, VATVQGLSGTGSLR & 3 & I \\
\hline 8 & GBLPA_ORYSJ & $\begin{array}{l}\text { Guanine nucleotide-binding protein } \\
\text { subunit beta-like protein A OS = } \\
\text { Oryza sativa subsp. Japonica }\end{array}$ & 1 & 110 & 9 & DGVTLLWDLAEGK, FSPNTFQPTIVSGSWDR & 2 & VIII \\
\hline 8 & H2AX_CICAR & $\begin{array}{l}\text { Histone H2AX OS = Cicer } \\
\text { arietinum }\end{array}$ & 1 & 108 & 15.1 & AGLQFPVGR, GKGEIGSASQEF & 2 & VII \\
\hline 4 & VATA_GOSHI & $\begin{array}{l}\text { V-type proton ATPase catalytic } \\
\text { subunit A OS = Gossypium } \\
\text { hirsutum }\end{array}$ & 2 & 108 & 5 & LAADTPLLTGQR, LVSQKFEDPAEGEEALVAK & 2 & VI \\
\hline 8 & PARP3_SOYBN & $\begin{array}{l}\text { Poly [ADP-ribose] polymerase } 3 \\
\text { OS = Glycine } \max \end{array}$ & 1 & 107 & 4.2 & VLCSQEIYK, LEPLVANFMK, LFEEITGNEFEPWER & 3 & III \\
\hline
\end{tabular}


Table 1. Cont.

\begin{tabular}{|c|c|c|c|c|c|c|c|c|}
\hline Fractions ${ }^{1}$ & $\begin{array}{l}\text { Protein } \\
\text { Accession }\end{array}$ & Protein Description & Similar $^{2}$ & Score $^{3}$ & Cover $(\%)$ & PEPTIDE Sequences & Sig. Peptide Number & $\begin{array}{l}\text { Func. } \\
\text { Cat. }^{4}\end{array}$ \\
\hline $3,4,(5)$ & CLPC1_ARATH & $\begin{array}{l}\text { Chaperone protein ClpC1, } \\
\text { chloroplastic OS = Arabidopsis } \\
\text { thaliana }\end{array}$ & 5 & 106 & 5.4 & TAIAEGLAQR,YRGEFEER, VLELSLEEAR & 3 & IX \\
\hline 8 & NDK1_ARATH & $\begin{array}{l}\text { Nucleoside diphosphate kinase } 1 \\
\text { OS = Arabidopsis thaliana }\end{array}$ & 2 & 103 & 9.4 & NVIHGSDSVESAR, NVIHGSDSVESARK & 2 & I \\
\hline 8 & RL13_TOBAC & $\begin{array}{l}\text { 60S ribosomal protein L13 } \\
\mathrm{OS}=\text { Nicotiana tabacum }\end{array}$ & 1 & 98 & 16.3 & SLEGLQTNVQR, KLAPTIGIAVDHR & 2 & $\mathrm{~V}$ \\
\hline 8 & RS5_CICAR & $\begin{array}{l}40 \mathrm{~S} \text { ribosomal protein } \mathrm{S} 5 \\
\text { (Fragment) } \mathrm{OS}=\text { Cicer arietinum }\end{array}$ & 2 & 95 & 15.2 & GSSNSYAIK, AQCPIVER, VNQAIYLLTTGAR & 3 & $\mathrm{~V}$ \\
\hline 5,6 & PDC2_ORYSI & $\begin{array}{l}\text { Pyruvate decarboxylase isozyme } 2 \\
\text { OS = Oryza sativa subsp. Indica }\end{array}$ & 2 & 94 & 4.5 & AVKPVLVGGPK, ILHHTIGLPDFSQELR & 2 & II \\
\hline 8 & HSP14_SOYBN & $\begin{array}{l}17.5 \mathrm{kDa} \text { class I heat shock protein } \\
\mathrm{OS}=\text { Glycine } \max \end{array}$ & 4 & 92 & 24.7 & AIEISG, ADIPGLK, VLQISGER, FRLPENAK & 4 & IX \\
\hline 6 & AMPL1_ARATH & $\begin{array}{l}\text { Leucine aminopeptidase } 1 \\
\text { OS = Arabidopsis thaliana }\end{array}$ & 2 & 92 & 4.6 & GLTFDSGGYNIK, TIEVNNTDAEGR & 2 & $\mathrm{I} / \mathrm{IX}$ \\
\hline 6 & ACT5_ARATH & $\begin{array}{l}\text { Putative actin-5 OS = Arabidopsis } \\
\text { thaliana }\end{array}$ & 1 & 92 & 15.9 & AGFAGDDAPR, IWHHTFYNELR & 2 & VII \\
\hline 8 & RS14_CHLRE & $\begin{array}{l}\text { 40S ribosomal protein } \mathrm{S} 14 \\
\mathrm{OS}=\text { Chlamydomonas reinhardtii }\end{array}$ & 1 & 87 & 15.7 & TPGPGAQSALR, IEDVTPIPTDSTR & 2 & $\mathrm{~V}$ \\
\hline 8 & RS3A1_VITVI & $\begin{array}{l}\text { 40S ribosomal protein S3a-1 } \\
\mathrm{OS}=\text { Vitis vinifera }\end{array}$ & 2 & 86 & 6.5 & TTDNYTLR, LRAEDVQGR & 2 & $\mathrm{~V}$ \\
\hline 7 & AAT3_ARATH & $\begin{array}{l}\text { Aspartate aminotransferase, } \\
\text { chloroplastic OS = Arabidopsis } \\
\text { thaliana }\end{array}$ & 1 & 83 & 4.9 & LNLGVGAYR, TEEGKPLVLNVVR & 2 & I \\
\hline 1 & COB21_ORYSJ & $\begin{array}{l}\text { Coatomer subunit beta-1 OS = } \\
\text { Oryza sativa subsp. Japonica }\end{array}$ & 1 & 83 & 4.5 & HNEIQTVNIK, DTNTFASASLDR & 2 & VI \\
\hline
\end{tabular}


Table 1. Cont.

\begin{tabular}{|c|c|c|c|c|c|c|c|c|}
\hline Fractions ${ }^{1}$ & $\begin{array}{l}\text { Protein } \\
\text { Accession }\end{array}$ & Protein Description & Similar $^{2}$ & Score $^{3}$ & Cover $(\%)$ & PEPTIDE Sequences & Sig. Peptide Number & $\begin{array}{l}\text { Func. } \\
\text { Cat. }{ }^{4}\end{array}$ \\
\hline 8 & GRDH1_ARATH & $\begin{array}{l}\text { Glucose and ribitol dehydrogenase } \\
\text { homolog } 1 \text { OS = Arabidopsis thaliana }\end{array}$ & 3 & 83 & 8 & GAIVAFTR, EGSSIINTTSVNAYK & 2 & II \\
\hline 8 & ANXD1_ARATH & I Annexin D1 OS = Arabidopsis thaliana & 1 & 80 & 5 & AQINATFNR, SKAQINATFNR & 2 & IX \\
\hline 7 & PDI21_ORYSJ & $\begin{array}{l}\text { Protein disulfide isomerase-like 2-1 } \\
\text { OS = Oryza sativa subsp. Japonica }\end{array}$ & 1 & 80 & 10.9 & KLAPEYEK, YGVSGFPTLK, YGVSGYPTIQWFPK & 3 & $\mathrm{v}$ \\
\hline $8,(6)$ & ATPAM_NICPL & $\begin{array}{l}\text { ATP synthase subunit alpha, } \\
\text { mitochondrial OS = Nicotiana } \\
\text { plumbaginifolia }\end{array}$ & 4 & 79 & 9.4 & VVSVGDGIAR, TAIAIDTILNQK & 2 & I \\
\hline $8,(1)$ & CB2_PHYPA & $\begin{array}{l}\text { Chlorophyll a-b binding protein, } \\
\text { chloroplastic OS = Physcomitrella } \\
\text { patens subsp. Patens }\end{array}$ & 1 & 75 & 3.7 & ELEVIHAR, NRELEVIHAR & 2 & II \\
\hline 8 & HSP12_SOYBN & $\begin{array}{l}\text { Class I heat shock protein (Fragment) } \\
\text { OS = Glycine } \max \end{array}$ & 1 & 75 & 18.9 & AIEISG, ILQISGER & 2 & IX \\
\hline 8 & BAS1_ORYSJ & $\begin{array}{l}\text { 2-Cys peroxiredoxin BAS1, } \\
\text { chloroplastic OS = Oryza sativa subsp. } \\
\text { Japonica }\end{array}$ & 1 & 69 & 9.6 & LSDYIGKK, SGGLGDLKYPLISDVTK & 2 & IX \\
\hline 8 & RLA0_LUPLU & $\begin{array}{l}60 \mathrm{~S} \text { acidic ribosomal protein } \mathrm{P} 0 \\
\mathrm{OS}=\text { Lupinus luteus }\end{array}$ & 1 & 69 & 7.5 & VGSSEAALLAK, GTVEIITPVELIK & 2 & $\mathrm{~V}$ \\
\hline 7 & EF1G2_ORYSJ & $\begin{array}{l}\text { Elongation factor } 1 \text {-gamma } 2 \\
\text { OS = Oryza sativa subsp. Japonica }\end{array}$ & 1 & 68 & 5 & NPLDLLPPSK, SFTSEFPHVER & 2 & $\mathrm{~V}$ \\
\hline 1 & MDAR_SOLLC & $\begin{array}{l}\text { Monodehydroascorbate reductase } \\
\text { OS = Solanum lycopersicum }\end{array}$ & 1 & 68 & 9.7 & AYLFPEGAAR,IVGAFLESGSPEENKAIAK & 2 & IX \\
\hline
\end{tabular}


Table 1. Cont.

\begin{tabular}{|c|c|c|c|c|c|c|c|c|}
\hline Fractions ${ }^{1}$ & $\begin{array}{l}\text { Protein } \\
\text { Accession }\end{array}$ & Protein Description & Similar $^{2}$ & Score $^{3}$ & Cover $(\%)$ & PEPTIDE Sequences & Sig. Peptide Number & $\begin{array}{l}\text { Func. } \\
\text { Cat. }{ }^{4}\end{array}$ \\
\hline 7 & RSSA_BRANA & 40S ribosomal protein SA OS = Brassica napus & 1 & 65 & 10.3 & LLILTDPR, VIVAIENPQDIIVQSARPYGQR & 2 & $\mathrm{~V}$ \\
\hline 6,8 & IF4A1_ARATH & $\begin{array}{l}\text { Eukaryotic initiation factor } 4 \mathrm{~A}-1 \\
\mathrm{OS}=\text { Arabidopsis thaliana }\end{array}$ & 1 & 65 & 8.3 & ELAQQIEK, VLITTDLLAR & 2 & $\mathrm{~V}$ \\
\hline 7 & HSP11_PEA & $\begin{array}{l}18.1 \mathrm{kDa} \text { class I heat shock protein OS }=\text { Pisum } \\
\text { sativum }\end{array}$ & 1 & 64 & 14.6 & SIEISG, VLQISGER & 2 & IX \\
\hline 8 & RS16_FRIAG & $\begin{array}{l}40 \mathrm{~S} \text { ribosomal protein } \mathrm{S} 16 \mathrm{OS}=\text { Fritillaria } \\
\text { agrestis }\end{array}$ & 1 & 64 & 12.4 & ALVAYYQK, AFEPILLLGR & 2 & $\mathrm{~V}$ \\
\hline 8 & RL51_ARATH & $\begin{array}{l}60 \mathrm{~S} \text { ribosomal protein } \mathrm{L} 5-1 \mathrm{OS}=\text { Arabidopsis } \\
\text { thaliana }\end{array}$ & 1 & 64 & 7.3 & KLTYEER, GALDGGLDIPHSDKR & 2 & $\mathrm{~V}$ \\
\hline 4 & HSP7M_PHAVU & $\begin{array}{l}\text { Heat shock } 70 \mathrm{kDa} \text { protein, mitochondrial } \\
\text { OS = Phaseolus vulgaris }\end{array}$ & 1 & 64 & 6.1 & HLNITLTR,SSGGLSEDEIEK & 2 & IX \\
\hline 8,7 & HSP12_MEDSA & $\begin{array}{l}18.2 \mathrm{kDa} \text { class I heat shock protein } \\
\mathrm{OS}=\text { Medicago sativa }\end{array}$ & 1 & 63 & 22.8 & TIDISG, VLQISGER, FRLPENAK & 3 & IX \\
\hline 8 & RS102_ARATH & $\begin{array}{l}40 \mathrm{~S} \text { ribosomal protein } \mathrm{S} 10-2 \mathrm{OS}=\text { Arabidopsis } \\
\text { thaliana }\end{array}$ & 1 & 61 & 8.9 & TYLNLPSEIVPATLK, TYLNLPSEIVPATLKK & 2 & $\mathrm{~V}$ \\
\hline 8 & RS193_ARATH & $\begin{array}{l}40 \mathrm{~S} \text { ribosomal protein } \mathrm{S} 19-3 \mathrm{OS}=\text { Arabidopsis } \\
\text { thaliana }\end{array}$ & 1 & 60 & 15.4 & DVSPHEFVK, ELAPYDPDWYYIR & 2 & $\mathrm{~V}$ \\
\hline 1 & CYF_AETCO & Apocytochrome f OS = Aethionema cordifolium & 2 & 60 & 8.7 & NILVIGPVPGQK, SNNTVYNATAGGIISK & 2 & II \\
\hline 8 & UBIQP_ACECL & $\begin{array}{l}\text { Polyubiquitin (Fragment) OS = Acetabularia } \\
\text { cliftonii }\end{array}$ & 1 & 60 & 8.7 & IIFAGK, TLADYNIQK, ESTLHLVLR & 3 & $\mathrm{~V}$ \\
\hline
\end{tabular}


Table 1. Cont.

\begin{tabular}{|c|c|c|c|c|c|c|c|c|}
\hline Fractions ${ }^{1}$ & $\begin{array}{l}\text { Protein } \\
\text { Accession }\end{array}$ & Protein Description & Similar $^{2}$ & Score $^{3}$ & Cover $(\%)$ & PEPTIDE Sequences & $\begin{array}{l}\text { Sig. Peptide } \\
\text { Number }\end{array}$ & $\begin{array}{l}\text { Func. } \\
\text { Cat. }^{4}\end{array}$ \\
\hline 8 & RL40A_ARATH & $\begin{array}{l}\text { Ubiquitin-60S ribosomal protein } \\
\text { L40-1 OS = Arabidopsis thaliana }\end{array}$ & 1 & 60 & 37.5 & LIFAGK, TLADYNIQK, ESTLHLVLR & 3 & $\mathrm{~V}$ \\
\hline 3 & UREA_CANEN & Urease OS = Canavalia ensiformis & 1 & 59 & 3 & NYFLF, TIHTYHSEGAGGGHAPDIIK & 2 & $\mathrm{I}$ \\
\hline 8 & RS13_PEA & $\begin{array}{l}\text { 40S ribosomal protein } \mathrm{S} 13 \\
\mathrm{OS}=\text { Pisum sativum }\end{array}$ & 1 & 58 & 17.2 & DSHGIAQVK, AHGLAPEIPEDLYHLIK & 2 & $\mathrm{~V}$ \\
\hline 1,8 & RAN_VICFA & $\begin{array}{l}\text { GTP-binding nuclear protein } \\
\text { Ran/TC4 OS = Vicia } f a b a\end{array}$ & 2 & 58 & 13.1 & HLTGEFEK, NLQYYEISAK & 2 & III/VI \\
\hline 7 & PYRB_ARATH & $\begin{array}{l}\text { Aspartate carbamoyltransferase, } \\
\text { chloroplastic OS = Arabidopsis } \\
\text { thaliana }\end{array}$ & 1 & 57 & 5.4 & GETLEDTIR, LGGEVLTTENAR & 2 & I \\
\hline 8 & HSP11_CHERU & $\begin{array}{l}18.3 \mathrm{kDa} \text { class I heat shock protein } \\
\mathrm{OS}=\text { Chenopodium rubrum }\end{array}$ & 1 & 52 & 18.6 & FRLPENAK, IDWKETPEAHVFK & 2 & IX \\
\hline 5 & CLAH1_ARATH & $\begin{array}{l}\text { Clathrin heavy chain } 1 \\
\mathrm{OS}=\text { Arabidopsis thaliana }\end{array}$ & 1 & 51 & 0.9 & ILALK, SPEQVSAAVK & 2 & VI \\
\hline 6 & PDI_RICCO & $\begin{array}{l}\text { Protein disulfide-isomerase } \\
\text { OS = Ricinus communis }\end{array}$ & 1 & 49 & 4.2 & FFNSPDAK, SEPIPEVNNEPVK & 2 & $\mathrm{~V}$ \\
\hline 7 & PDIA6_MEDSA & $\begin{array}{l}\text { Probable protein disulfide- } \\
\text { isomerase } \mathrm{A} 6 \mathrm{OS}=\text { Medicago } \\
\text { sativa }\end{array}$ & 1 & 48 & 7.4 & KLAPEYEK, YGVSGYPTIQWFPK & 2 & $\mathrm{~V}$ \\
\hline 4 & SUSY_MEDSA & $\begin{array}{l}\text { Sucrose synthase } \mathrm{OS}=\text { Medicago } \\
\text { sativa }\end{array}$ & 1 & 46 & 2.9 & NITGLVEWYGK,SGFHIDPYHGDR & 2 & II \\
\hline 7 & FKB62_ARATH & $\begin{array}{l}\text { Peptidyl-prolyl cis-trans isomerase } \\
\text { FKBP62 OS = Arabidopsis thaliana }\end{array}$ & 1 & 42 & 4.4 & SDGVEFTVK, FTLGQGQVIK & 2 & $\mathrm{~V}$ \\
\hline 5 & DLDH2_ARATH & $\begin{array}{l}\text { Dihydrolipoyl dehydrogenase } 2 \text {, } \\
\text { mitochondrial OS = Arabidopsis } \\
\text { thaliana }\end{array}$ & 1 & 40 & 3.4 & AAQLGLK, SLPGITIDEK & 2 & II \\
\hline
\end{tabular}


Table 1. Cont.

\begin{tabular}{|c|c|c|c|c|c|c|c|c|}
\hline Fractions ${ }^{1}$ & $\begin{array}{l}\text { Protein } \\
\text { Accession }\end{array}$ & Protein Description & Similar $^{2}$ & Score $^{3}$ & Cover $(\%)$ & PEPTIDE Sequences & $\begin{array}{l}\text { Sig. Peptide } \\
\text { Number }\end{array}$ & $\begin{array}{l}\text { Func. } \\
\text { Cat. }^{4}\end{array}$ \\
\hline 7 & WIT2_ARATH & $\begin{array}{l}\text { WPP domain-interacting tail- } \\
\text { anchored protein } 2 \\
\text { OS = Arabidopsis thaliana }\end{array}$ & 1 & 39 & 3.3 & ELELEK,AESGEAKIK & 2 & III \\
\hline 8 & TBA_PRUDU & $\begin{array}{l}\text { Tubulin alpha chain OS = Prunus } \\
\text { dulcis }\end{array}$ & 2 & 37 & 7.8 & DVNAAVATIK, LVSQVISSLTASLR & 2 & VII \\
\hline 7 & PER1B_ARMRU & $\begin{array}{l}\text { Peroxidase C1B OS = Armoracia } \\
\text { rusticana }\end{array}$ & 1 & 35 & 5.7 & VPLGR, MGNITPLTGTQGEIR & 2 & IX \\
\hline $7,(8,6)$ & YCF1_IPOPU & $\begin{array}{l}\text { Putative membrane protein ycf } 1 \\
\text { OS = Ipomoea purpurea }\end{array}$ & 3 & 35 & 1.3 & ALILK, IVIEK,VIQEKER & 3 & $\mathrm{x}$ \\
\hline 6 & RFS_ORYSJ & $\begin{array}{l}\text { Galactinol--sucrose } \\
\text { galactosyltransferase OS = Oryza } \\
\text { sativa subsp. } \text { Japonica }\end{array}$ & 1 & 27 & 2.8 & VELAK, LMEEK & 2 & II \\
\hline 7 & Y1497_ARATH & $\begin{array}{l}\text { Probable receptor-like protein } \\
\text { kinase At1g49730 } \\
\text { OS = Arabidopsis thaliana }\end{array}$ & 1 & 20 & 1.7 & FLLAK, NLVALK & 2 & $\mathrm{~V}$ \\
\hline
\end{tabular}

${ }^{1}$ Fraction corresponding to slice of the 1-D gel in which matches for the protein were found. Numbers in parenthesis indicate fractions where additional similar matches (see 2.) were found. ${ }^{2}$ Number of protein matches of high taxonomical and sequence similarity grouped together with this match. (Match displayed was the top-scored one.) ${ }^{3}$ MASCOT score. ${ }^{4}$ I: metabolism, II: energy, III: cell growth/division, IV: transcription, V: protein synthesis/destination, VI: transporters, VII: cell structure, VIII: signal transduction, IX: disease/stress defense, and X: unclassified. 
Table 2. List of top-scored non-redundant (nr) protein matches of the lotus embryo 1-D shotgun mass spectroscopy results, as matched to Green Plant proteome database (SwissProt 57.0).

\begin{tabular}{|c|c|c|c|c|c|c|c|c|}
\hline Fractions $^{1}$ & Protein Accession & Protein Description & Similar $^{2}$ & Score $^{3}$ & Cover $(\%)$ & Peptide sequences & $\begin{array}{l}\text { Sig. Peptide } \\
\text { Number }\end{array}$ & $\begin{array}{l}\text { Func. } \\
\text { Cat. }^{4}\end{array}$ \\
\hline $6,(5,2,1,7,3)$ & ENO1_HEVBR & Enolase $1 \mathrm{OS}=$ Hevea brasiliensis & 19 & 1125 & 42 & $\begin{array}{l}\text { TAIAK, YNQLLR, LTSEIGEK, DGGSDYLGK, } \\
\text { AGWGVMASHR, MGAEVYHHLK, DGGSDYLGKGVSK, } \\
\text { VQIVGDDLLVTNPK, VNQIGSVTESIEAVK, } \\
\text { EAMKMGAEVYHHLK, AAVPSGASTGIYEALELR, } \\
\text { LAMQEFMILPVGASSFK, SGETEDTFIADLSVGLATGQIK, } \\
\text { YGQDATNVGDEGGFAPNIQENK, } \\
\text { KYGQDATNVGDEGGFAPNIQENK, } \\
\text { YGQDATNVGDEGGFAPNIQENKEGLELLK }\end{array}$ & 16 & II \\
\hline $4,(1,2,3,5)$ & HSP7C_PETHY & $\begin{array}{l}\text { Heat shock cognate } 70 \mathrm{kDa} \text { protein } \\
\mathrm{OS}=\text { Petunia hybrida }\end{array}$ & 33 & 922 & 33.6 & $\begin{array}{l}\text { IEEVD, DISGNPR, NTTIPTKK, ITITNDKGR, } \\
\text { DAGVIAGLNVMR, MVNHFVQEFK, NALENYAYNMR, } \\
\text { MVNHFVQEFKR, TTPSYVGFTDTER, ARFEELNMDLFR, } \\
\text { IINEPTAAAIAYGLDK, NQVAMNPINTVFDAK } \\
\text { ATAGDTHLGGEDFDNR, NQVAMNPINTVFDAK, } \\
\text { NAVVTVPAYFNDSQR, EQVFSTYSDNQPGVLIQVYEGER }\end{array}$ & 16 & IX \\
\hline $1,2,3,4,5,6,7$ & ACT_GOSHI & Actin OS = Gossypium hirsutum & 14 & 903 & 50.7 & $\begin{array}{l}\text { DLTDALMK, AGFAGDDAPR, IKVVAPPER, GYSFTTTAER, } \\
\text { HTGVMVGMGQK, EITALAPSSMK, DAYVGDEAQSK, } \\
\text { AVFPSIVGRPR, IWHHTFYNELR, LDLAGRDLTDALMK, } \\
\text { GYSFTTTAEREIVR, SYELPDGQVITIGAER, } \\
\text { VAPEEHPVLLTEAPLNPK, VAPEEHPVLLTEAPLNPK, } \\
\text { TTGIVLDSGDGVSHTVPIYEGYALPHAILR }\end{array}$ & 15 & VII \\
\hline
\end{tabular}


Table 2. Cont.

\begin{tabular}{|c|c|c|c|c|c|c|c|c|}
\hline Fractions $^{1}$ & Protein Accession & Protein Description & Similar $^{2}$ & Score $^{3}$ & Cover $(\%)$ & Peptide Sequences & $\begin{array}{l}\text { Sig. Peptide } \\
\text { Number }\end{array}$ & $\begin{array}{l}\text { Func. } \\
\text { Cat. }^{4}\end{array}$ \\
\hline $6,(1,2,3,7)$ & ACT12_SOLTU & $\begin{array}{l}\text { Actin-100 (Fragment) OS = Solanum } \\
\text { tuberosum }\end{array}$ & 5 & 872 & 53.5 & $\begin{array}{l}\text { AGFAGDDAPR, IKVVAPPER, HTGVMVGMGQK, } \\
\text { EITALAPSSMK, DAYVGDEAQSK, AVFPSIVGRPR, } \\
\text { DAYVGDEAQSKR, GEYDESGPSIVHR, IWHHTFYNELR, } \\
\text { SYELPDGQVITIGAER, LAYVALDYEQELETAK, } \\
\text { YPIEHGIVSNWDDMEK, } \\
\text { TTGIVLDSGDGVSHTVPIYEGYALPHAILR }\end{array}$ & 13 & VII \\
\hline $7,(8,2)$ & G3PC_ANTMA & $\begin{array}{l}\text { Glyceraldehyde-3-phosphate } \\
\text { dehydrogenase, cytosolic } \\
\text { OS = Antirrhinum majus }\end{array}$ & 20 & 749 & 43.6 & $\begin{array}{l}\text { VALQR, SSIFDAK, KATYEQIK, AAIKEESEGK, } \\
\text { AGIALNDNFVK, DAPMFVVGVNEK, } \\
\text { AASFNIIPSSTGAAK, VPTVDVSVVDLTVR, } \\
\text { VPTVDVSVVDLTVRLEK, FGIVEGLMTTVHSITATQK, } \\
\text { GILGYTEDDVVSTDFVGDSR, } \\
\text { LTGMSFRVPTVDVSVVDLTVR, } \\
\text { LKGILGYTEDDVVSTDFVGDSR, } \\
\text { VINDRFGIVEGLMTTVHSITATQK }\end{array}$ & 14 & II \\
\hline $4,(1,5,2)$ & HSP83_IPONI & Heat shock protein $83 \mathrm{OS}=$ Ipomoea nil & 4 & 717 & 31 & $\begin{array}{l}\text { VIVTTK, VVVSDR, KLVSATK, AILFVPK, EMLQQNK, } \\
\text { DVDGEQLGR, FESLTDKSK, APFDLFDTR, } \\
\text { AVENSPFLER, LGIHEDSQNR, DIYYITGESK, } \\
\text { LDAQPELFIR, RAPFDLFDTR, ADLVNNLGTIAR, } \\
\text { ELISNASDALDK, KAVENSPFLER, HFSVEGQLEFK, } \\
\text { GVVDSDDLPLNISR, ELISNASDALDKIR, } \\
\text { SGDELTSLKDYVTR, KPEEITKEEYASFYK, } \\
\text { HSEFISYPIYLWTEK, ITLFLKEDQLEYLEER }\end{array}$ & 23 & IX \\
\hline 6 & ATPBM_MAIZE & $\begin{array}{l}\text { ATP synthase subunit beta, mitochondrial } \\
\text { OS = Zea mays }\end{array}$ & 3 & 712 & 31.8 & $\begin{array}{l}\text { IGLFGGAGVGK, VVDLLAPYQR, TIAMDGTEGLVR, } \\
\text { AHGGFSVFAGVGER, VGLTGLTVAEHFR, } \\
\text { VLNTGSPITVPVGR, TVLIMELINNVAK, } \\
\text { FTQANSEVSALLGR, QISELGIYPAVDPLDSTSR, } \\
\text { EAPAFVEQATEQQILVTGIK, } \\
\text { IPSAVGYQPTLATDLGGLQER }\end{array}$ & 11 & I \\
\hline
\end{tabular}


Table 2. Cont

\begin{tabular}{|c|c|c|c|c|c|c|c|c|}
\hline Fractions $^{1}$ & Protein Accession & Protein Description & Similar $^{2}$ & Score $^{3}$ & Cover $(\%)$ & Peptide Sequences & $\begin{array}{l}\text { Sig. Peptide } \\
\text { Number }\end{array}$ & $\begin{array}{l}\text { Func. } \\
\text { Cat. }^{4}\end{array}$ \\
\hline $4,(5,2,1,3)$ & HSP7E_SPIOL & $\begin{array}{l}\text { Chloroplast envelope membrane } 70 \mathrm{kDa} \\
\text { heat shock-related protein OS = Spinacia } \\
\text { oleracea }\end{array}$ & 5 & 631 & 31.2 & $\begin{array}{l}\text { NTTIPTKK, LSKEEIEK, TRDNNLLGK, } \\
\text { DAGVISGLNVMR, EIAEAYLGSTVK, } \\
\text { NALENYAYNMR, TTPSYVAFTDSER, } \\
\text { IINEPTAAAIAYGLDK, ATAGDTHLGGEDFDNR, } \\
\text { NQVAMNPINTVFDAK, NAVVTVPAYFNDSQR, } \\
\text { EQVFSTYSDNQPGVLIQVYEGER }\end{array}$ & 12 & IX \\
\hline $4,(2,1,5)$ & HSP81_ORYSI & $\begin{array}{l}\text { Heat shock protein } 81-1 \mathrm{OS}=\text { Oryza } \\
\text { sativa } \text { subsp. Indica }\end{array}$ & 9 & 610 & 35.1 & $\begin{array}{l}\text { NLVKK, VVVTTK, IAELLR, KLVSATK, EMLQQNK, } \\
\text { FESLTDKSK, APFDLFDTR, DSSMAGYMSSK, } \\
\text { RAPFDLFDTR, KAVENSPFLEK, SDLVNNLGTIAR, } \\
\text { HFSVEGQLEFK, EVSHEWSLVNK, } \\
\text { GIVDSEDLPLNISR, SLTNDWEEHLAVK, } \\
\text { SGDELTSLKDYVTR, LDAQPELFIHIVPDK, } \\
\text { HSEFISYPISLWTEK, KPEEITKEEYAAFYK, } \\
\text { MKEGQNDIYYITGESK, KHSEFISYPISLWTEK }\end{array}$ & 21 & IX \\
\hline $6,(3,1,2)$ & TBB_HORVU & $\begin{array}{l}\text { Tubulin beta chain } \mathrm{OS}=\text { Hordeum } \\
\text { vulgare }\end{array}$ & 21 & 583 & 39.1 & $\begin{array}{l}\text { YLTASAMFR, IREEYPDR, LAVNLIPFPR, } \\
\text { VSEQFTAMFR, YTGTSDLQLER, MMLTFSVFPSK, } \\
\text { EVDEQMINVQNK, LHFFMVGFAPLTSR, } \\
\text { AVLMDLEPGTMDSVR, LHFFMVGFAPLTSR, } \\
\text { NSSYFVEWIPNNVK, ALTVPELTQQMWDAK, } \\
\text { GHYTEGAELIDSVLDVVRK, } \\
\text { TGPYGQIFRPDNFVFGQSGAGNNWAK }\end{array}$ & 14 & VII \\
\hline $6,(1,7,3,4,2)$ & EF1A_TOBAC & $\begin{array}{l}\text { Elongation factor 1-alpha OS = Nicotiana } \\
\text { tabacum }\end{array}$ & 17 & 574 & 38.5 & $\begin{array}{l}\text { YDEIVK, GFVASNSK, EVSSYLK, QTVAVGVIK, } \\
\text { EVSSYLKK, RGFVASNSK, LPLQDVYK, ARYDEIVK, } \\
\text { IGGIGTVPVGR, STNLDWYK, STTTGHLIYK, } \\
\text { EHALLAFTLGVK, GFVASNSKDDPAK, } \\
\text { YYCTVIDAPGHR, YDEIVKEVSSYLK, } \\
\text { YYCTVIDAPGHRDFIK, MIPTKPMVVETFSEYPPLGR, } \\
\text { NMITGTSQADCAVLIIDSTTGGFEAGISK }\end{array}$ & 18 & $\mathrm{~V}$ \\
\hline
\end{tabular}


Table 2. Cont.

\begin{tabular}{|c|c|c|c|c|c|c|c|c|}
\hline Fractions ${ }^{1}$ & Protein Accession & Protein Description & Similar $^{2}$ & Score $^{3}$ & Cover $(\%)$ & Peptide Sequences & $\begin{array}{l}\text { Sig. Peptide } \\
\text { Number }\end{array}$ & $\begin{array}{l}\text { Func. } \\
\text { Cat. }^{4} \\
\end{array}$ \\
\hline $4,(1,2,5,4)$ & HS901_ARATH & $\begin{array}{l}\text { Heat shock protein } 90-1 \\
\text { OS = Arabidopsis thaliana }\end{array}$ & 6 & 539 & 26.4 & $\begin{array}{l}\text { VVVTTKVVVTTK, VVVSDR, KLVSATK, AILFVPK, } \\
\text { FESLTDKSK, APFDLFDTR, AVENSPFLER, } \\
\text { LGIHEDSQNR, DSSMSGYMSSK, RAPFDLFDTR, } \\
\text { ADLVNNLGTIAR, KAVENSPFLER, HFSVEGQLEFK, } \\
\text { TLSIIDSGIGMTK, GVVDSDDLPLNISR, } \\
\text { KPEEITKEEYAAFYK, HSEFISYPIYLWTEK }\end{array}$ & 17 & IX \\
\hline $4,(2,1,3)$ & METE_ARATH & $\begin{array}{l}\text { 5-methyltetrahydropteroyltriglutamate- } \\
\text { homocysteine methyltransferase } \\
\text { OS = Arabidopsis thaliana }\end{array}$ & 12 & 536 & 20.9 & $\begin{array}{l}\text { AAAALK, VVEVNALAK, SWLAFAAQK, } \\
\text { AVNEYKEAK, YLFAGVVDGR, SDEKLLSVFR, } \\
\text { FALESFWDGK, GNASVPAMEMTK, } \\
\text { YGAGIGPGVYDIHSPR, GMLTGPVTILNWSFVR }\end{array}$ & 10 & I \\
\hline 4 & ENPL_CATRO & $\begin{array}{l}\text { Endoplasmin homolog OS = } \\
\text { Catharanthus roseus }\end{array}$ & 3 & 472 & 12.6 & $\begin{array}{l}\text { NLGTIAK, FWNEFGK, YGWSSNMER, } \\
\text { ELISNASDALDK, IMQSQTLSDASK, } \\
\text { GLVDSDTLPLNVSR, ELISNASDALDKIR, } \\
\text { VFISDEFDELLPK, RVFISDEFDELLPK, } \\
\text { LMDIIINSLYSNKDIFLR }\end{array}$ & 10 & IX \\
\hline $4,(5,2)$ & BIP4_TOBAC & $\begin{array}{l}\text { Luminal-binding protein } 4 \\
\text { OS = Nicotiana tabacum }\end{array}$ & 6 & 454 & 21 & $\begin{array}{l}\text { LIGEAAK, NTVIPTKK, IMEYFIK, LSQEEIER, } \\
\text { ITITNDKGR, ALSSQHQVR, EAEEFAEEDKK, } \\
\text { IVNKDGKPYIQVK, ARFEELNNDLFR, } \\
\text { IINEPTAAAIAYGLDK, IKDAVVTVPAYFNDAQR }\end{array}$ & 11 & IX \\
\hline $4,(1,3,2,7)$ & EF2_BETVU & Elongation factor $2 \mathrm{OS}=$ Beta vulgaris & 6 & 454 & 16.6 & $\begin{array}{l}\text { DLYVK, VASDLPK, GGGQIIPTAR, MIPASDKGR, } \\
\text { IRPVLTVNK, EGALAEENMR, NMSVIAHVDHGK, } \\
\text { FGVDESKMMER, VFYASQLTAKPR, } \\
\text { LWGENFFDPATK, IRPVLTVNKMDR, } \\
\text { RVFYASQLTAKPR, GHVFEEMQRPGTPLYNIK, } \\
\text { RGHVFEEMQRPGTPLYNIK }\end{array}$ & 15 & $\mathrm{~V}$ \\
\hline
\end{tabular}


Table 2. Cont.

\begin{tabular}{|c|c|c|c|c|c|c|c|c|}
\hline Fractions ${ }^{1}$ & Protein Accession & Protein Description & Similar $^{2}$ & Score $^{3}$ & Cover $(\%)$ & Peptide Sequences & $\begin{array}{l}\text { Sig. Peptide } \\
\text { Number }\end{array}$ & $\begin{array}{l}\text { Func. } \\
\text { Cat. }^{4}\end{array}$ \\
\hline $4,(1,2,3)$ & HSP82_MAIZE & Heat shock protein $82 \mathrm{OS}=$ Zea mays & 5 & 429 & 16.1 & $\begin{array}{l}\text { VVVSDR, KLVSATK, APFDLFDTR, AVENSPFLER, } \\
\text { LGIHEDSQNR, RAPFDLFDTR, SDLVNNLGTIAR, } \\
\text { ELISNASDALDK, KAVENSPFLER, HFSVEGQLEFK, } \\
\text { GVVDSDDLPLNISR, ELISNASDALDKIR, } \\
\text { HSEFISYPIYLWTEK }\end{array}$ & 13 & IX \\
\hline $6,(2,3)$ & IF4A1_ORYSJ & $\begin{array}{l}\text { Eukaryotic initiation factor 4A-1 } \\
\mathrm{OS}=\text { Oryza sativa subsp. Japonica }\end{array}$ & 4 & 418 & 31.4 & $\begin{array}{l}\text { ALGDYLGVK, ELAQQIEK, KGVAINFVTR, } \\
\text { VLITTDLLAR, QSLRPDYIK, RDELTLEGIK, } \\
\text { GLDVIQQAQSGTGK, GIYAYGFEKPSAIQQR, } \\
\text { GFKDQIYDIFQLLPSK }\end{array}$ & 9 & $\mathrm{~V}$ \\
\hline $3,(2,1)$ & CAPPC_FLATR & $\begin{array}{l}\text { Phosphoenolpyruvate carboxylase } 2 \\
\text { OS = Flaveria trinervia }\end{array}$ & 32 & 417 & 18 & $\begin{array}{l}\text { GIAAGMQNTG, MNIGSRPSK, VILGDVRDK, } \\
\text { KPSGGIESLR, LSAAWQLYK, SPEEVFDALK, } \\
\text { RPLFGPDLPK, TPPTPQDEMR, QVSTFGLSLVR, } \\
\text { VTIDLVEMVFAK, AGMSYFHETIWK, AIPWIFAWTQTR, } \\
\text { VPYNAPLIQFSSWMGGDRDGNPR }\end{array}$ & 13 & I \\
\hline $6,(2)$ & ENO2_ARATH & $\begin{array}{l}\text { Bifunctional enolase } 2 / \text { transcriptional } \\
\text { activator OS = Arabidopsis thaliana }\end{array}$ & 2 & 391 & 33.3 & $\begin{array}{l}\text { YNQLLR, DGGSDYLGK, ISGDALKDLYK, } \\
\text { DGGSDYLGKGVSK, VNQIGSVTESIEAVK, } \\
\text { IVLPVPAFNVINGGSHAGNK, } \\
\text { SGETEDTFIADLAVGLSTGQIK, } \\
\text { YGQDATNVGDEGGFAPNIQENK, } \\
\text { KYGQDATNVGDEGGFAPNIQENK, } \\
\text { YGQDATNVGDEGGFAPNIQENKEGLELLK }\end{array}$ & 10 & IV \\
\hline $5,(2)$ & CH61_CUCMA & $\begin{array}{l}\text { Chaperonin CPN60-1, mitochondrial } \\
\text { OS = Cucurbita maxima }\end{array}$ & 6 & 387 & 33.33 & $\begin{array}{l}\text { ISSINAVVK, VTDALNATK, VTKDGVTVAK, } \\
\text { KISSINAVVK, IGGASEAEVGEK, IGVQIIQNALK, } \\
\text { IGGASEAEVGEKK, GYISPYFITNQK, } \\
\text { AAVEEGIVPGGGVALLYASK, } \\
\text { TPVHTIASNAGVEGAVVVGK }\end{array}$ & 10 & IX \\
\hline 4 & HSP7L_ARATH & $\begin{array}{l}\text { Heat shock } 70 \mathrm{kDa} \text { protein } 12 \\
\mathrm{OS}=\text { Arabidopsis thaliana }\end{array}$ & 1 & 382 & 16.8 & $\begin{array}{l}\text { NTVIPTKK, IMEYFIK, ALSSQHQVR, EAEEFAEEDKK, } \\
\text { ARFEELNNDLFR, ARFEELNNDLFR, } \\
\text { IINEPTAAAIAYGLDK, IKDAVVTVPAYFNDAQR }\end{array}$ & 8 & IX \\
\hline
\end{tabular}


Table 2. Cont.

\begin{tabular}{|c|c|c|c|c|c|c|c|c|}
\hline Fractions ${ }^{1}$ & Protein Accession & Protein Description & Similar $^{2}$ & Score $^{3}$ & Cover $(\%)$ & Peptide Sequences & $\begin{array}{l}\text { Sig. Peptide } \\
\text { Number }\end{array}$ & $\begin{array}{l}\text { Func. } \\
\text { Cat. }{ }^{4}\end{array}$ \\
\hline $2,(1)$ & CLAH1_ARATH & $\begin{array}{l}\text { Clathrin heavy chain } 1 \\
\text { OS = Arabidopsis thaliana }\end{array}$ & 4 & 374 & 10.3 & $\begin{array}{l}\text { TVDNDLALK, SPEQVSAAVK, VANVELYYK, DPTLAVVAYR, } \\
\text { FQELFAQTK, VEEDAVWSQVAK, GNLPGAENLVVQR, } \\
\text { EGLVSDAIESFIR, GNMQLFSVDQQR, KNLLENWLAEDK, } \\
\text { RGNLPGAENLVVQR, QLIDQVVSTALPESK, } \\
\text { YKEAAELAAESPQGILR }\end{array}$ & 13 & VI \\
\hline $6,(2,5,1)$ & ATPAM_PEA & $\begin{array}{l}\text { ATP synthase subunit alpha, } \\
\text { mitochondrial OS = Pisum } \\
\text { sativum }\end{array}$ & 1 & 364 & 29.4 & $\begin{array}{l}\text { VVSVGDGIAR, TGSIVDVPAGK, AAELTTLLESR, } \\
\text { VVDALGVPIDGR, TAIAIDTILNQK, KSVHEPMQTGLK, } \\
\text { GIRPAINVGLSVSR, EAFPGDVFYLHSR, ITNFYTNFQVDEIGR, } \\
\text { LTEVLKQPQYAPLPIEK, EVAAFAQFGSDLDAATQALLNR }\end{array}$ & 11 & I \\
\hline 5 & RUBB_PEA & $\begin{array}{l}\text { RuBisCO large subunit-binding } \\
\text { protein subunit beta, } \\
\text { chloroplastic OS = Pisum } \\
\text { sativum }\end{array}$ & 2 & 357 & 23.98 & $\begin{array}{l}\text { IAALK, VVLTK, NVVLESK, VEDALNATK, IVNDGVTVAK, } \\
\text { KGVVTLEEGK, LADLVGVTLGPK, GYISPYFVTDSEK, } \\
\text { EVELEDPVENIGAK, TNDLAGDGTTTSVVLAQGLIAEGVK, } \\
\text { IVNDGVTVAKEVELEDPVENIGAK }\end{array}$ & 11 & I \\
\hline $5,(2)$ & PGMC_PEA & $\begin{array}{l}\text { Phosphoglucomutase, } \\
\text { cytoplasmic OS = Pisum sativum }\end{array}$ & 5 & 333 & 41.16 & $\begin{array}{l}\text { YLFEDGSR, FFEVPTGWK, LSGTGSEGATIR, } \\
\text { SMPTSAALDVVAK, YDYENVDAGAAK }\end{array}$ & 5 & II \\
\hline $6,(2)$ & SAHH_MESCR & $\begin{array}{l}\text { Adenosylhomocysteinase } \\
\text { OS }=\text { Mesembryanthemum } \\
\text { crystallinum }\end{array}$ & 6 & 330 & 11.1 & $\begin{array}{l}\text { ATDVMIAGK, HSLPDGLMR, ITIKPQTDR, TEFGPSQPFK, } \\
\text { LVGVSEETTTGVK, TEFGPSQPFKGAK, LVGVSEETTTGVKR }\end{array}$ & 7 & I \\
\hline 7 & PGKY_TOBAC & $\begin{array}{l}\text { Phosphoglycerate kinase, } \\
\text { cytosolic OS = Nicotiana } \\
\text { tabacum }\end{array}$ & 7 & 302 & 21.7 & $\begin{array}{l}\text { LAELSGK, YSLKPLVPR, YLKPAVAGFLMQK, } \\
\text { GVSLLLPTDVVIADK, GVTTIIGGGDSVAAVEK, } \\
\text { LASLADLYVNDAFGTAHR, KLASLADLYVNDAFGTAHR }\end{array}$ & 7 & II \\
\hline 4 & SUSY_SOYBN & $\begin{array}{l}\text { Sucrose synthase OS }=\text { Glycine } \\
\max \end{array}$ & 12 & 295 & 13.4 & $\begin{array}{l}\text { YLEMFYALK, VVHGIDVFDPK, NITGLVEWYGK, } \\
\text { ELVNLVVVAGDR, LLPDAVGTTCGQR, SGFHIDPYHGDR, } \\
\text { LGVTQCTIAHALEK }\end{array}$ & 7 & II \\
\hline 5 & CPNB3_ARATH & $\begin{array}{l}\text { Chaperonin } 60 \text { subunit beta } 3 \text {, } \\
\text { chloroplastic } \mathrm{OS}=\text { Arabidopsis } \\
\text { thaliana }\end{array}$ & 1 & 292 & 25.35 & $\begin{array}{l}\text { VVLTK, NVVLESK, VEDALNATK, KGVVTLEEGK, } \\
\text { LADLVGVTLGPK, GYISPYFVTDSEK, EVELEDPVENIGAK, } \\
\text { TNDLAGDGTTTSVVLAQGLIAEGVK }\end{array}$ & 8 & IX \\
\hline
\end{tabular}


Table 2. Cont.

\begin{tabular}{|c|c|c|c|c|c|c|c|c|}
\hline Fractions ${ }^{1}$ & Protein Accession & Protein Description & Similar $^{2}$ & Score $^{3}$ & Cover $(\%)$ & Peptide Sequences & $\begin{array}{l}\text { Sig. Peptide } \\
\text { Number }\end{array}$ & $\begin{array}{l}\text { Func. } \\
\text { Cat. }^{4}\end{array}$ \\
\hline $7,(8)$ & MDHC2_ARATH & $\begin{array}{l}\text { Malate dehydrogenase, cytoplasmic } 2 \\
\text { OS = Arabidopsis thaliana }\end{array}$ & 2 & 288 & 23.2 & $\begin{array}{l}\text { GAAIIK, NVSIYK, SQASALEK, EFAPSIPEK, } \\
\text { MELVDAAFPLLK, VLVVANPANTNALILK, } \\
\text { VLVTGAAGQIGYALVPMIAR }\end{array}$ & 7 & II \\
\hline $8,(1)$ & 1433E_TOBAC & $\begin{array}{l}\text { 14-3-3-like protein E OS = Nicotiana } \\
\text { tabacum }\end{array}$ & 19 & 284 & 29.8 & $\begin{array}{l}\text { NVIGAR, VFYLK, YLAEFK, MKGDYHR, } \\
\text { NLLSVAYK, IISSIEQK, TVDVEELTVEER, } \\
\text { IISSIEQKEESR, SAQDIALAELAPTHPIR } \\
\end{array}$ & 9 & VIII \\
\hline 5 & VATA_GOSHI & $\begin{array}{l}\text { V-type proton ATPase catalytic subunit A } \\
\text { OS = Gossypium hirsutum }\end{array}$ & 2 & 272 & 49.1 & $\begin{array}{l}\text { SGDVYIPR, TVISQALSK, LAADTPLLTGQR, } \\
\text { LAEMPADSGYPAYLAAR, LTTFEDSEKESEYGYVR, } \\
\text { LVSQKFEDPAEGEEALVAK }\end{array}$ & 6 & VI \\
\hline $4,(3,2,1)$ & CD48A_ARATH & $\begin{array}{l}\text { Cell division control protein } 48 \text { homolog } \\
\text { A OS = Arabidopsis thaliana }\end{array}$ & 3 & 265 & 18.5 & $\begin{array}{l}\text { TLLAK, KGDLFLVR, RSVSDADIR, DFSTAILER, } \\
\text { LAEDVDLER, GILLYGPPGSGK, LAGESESNLRK, } \\
\text { IVSQLLTLMDGLK, ELVELPLRHPQLFK, } \\
\text { NAPSIIFIDEIDSIAPK }\end{array}$ & 10 & III/IV \\
\hline 7 & ALF_CICAR & $\begin{array}{l}\text { Fructose-bisphosphate aldolase, } \\
\text { cytoplasmic isozyme OS = Cicer } \\
\text { arietinum }\end{array}$ & 1 & 245 & 11.1 & $\begin{array}{l}\text { GILAADESTGTIGK, GILAADESTGTIGKR, } \\
\text { YHDELIANAAYIGTPGK }\end{array}$ & 3 & II \\
\hline 7 & MDHM_CITLA & $\begin{array}{l}\text { Malate dehydrogenase, mitochondrial } \\
\text { OS = Citrullus lanatus }\end{array}$ & 2 & 235 & 17.6 & $\begin{array}{l}\text { LFGVTTLDVVR, TQDGGTEVVEAK, } \\
\text { DDLFNINAGIVK, RTQDGGTEVVEAK, } \\
\text { VAVLGAAGGIGQPLALLMK }\end{array}$ & 5 & II \\
\hline 6,7 & ACT5_ARATH & $\begin{array}{l}\text { Putative actin-5 OS = Arabidopsis } \\
\text { thaliana }\end{array}$ & 1 & 213 & 20.4 & $\begin{array}{l}\text { AGFAGDDAPR, IKVVAPPER, IWHHTFYNELR, } \\
\text { TTGIVLDSGDGVSHTVPIYEGYALPHAILR }\end{array}$ & 4 & VII \\
\hline 6 & UGPA_MUSAC & $\begin{array}{l}\text { UTP--glucose-1-phosphate } \\
\text { uridylyltransferase OS = Musa acuminata }\end{array}$ & 3 & 199 & 18 & $\begin{array}{l}\text { VANFLSR, GGTLISYEGR, VLQLETAAGAAIR, } \\
\text { FFDHAIGINVPR, LQSAVAELNQISENEK }\end{array}$ & 5 & II \\
\hline 8 & ADT1_GOSHI & $\begin{array}{l}\text { ADP,ATP carrier protein 1, mitochondrial } \\
\text { OS = Gossypium hirsutum }\end{array}$ & 2 & 194 & 8.8 & SSLDAFSQILK,LLIQNQDEMIK, YFPTQALNFAFK & 3 & VI \\
\hline 8 & RAN_VICFA & $\begin{array}{l}\text { GTP-binding nuclear protein Ran/TC4 } \\
\text { OS = Vicia faba }\end{array}$ & 1 & 193 & 26.2 & $\begin{array}{l}\text { NVPTWHR, HLTGEFEK, AKQVTFHR, } \\
\text { LVIVGDGGTGK, NLQYYEISAK, } \\
\text { SNYNFEKPFLYLAR }\end{array}$ & 6 & VIII \\
\hline
\end{tabular}


Table 2. Cont.

\begin{tabular}{|c|c|c|c|c|c|c|c|c|}
\hline Fractions ${ }^{1}$ & Protein Accession & Protein Description & Similar $^{2}$ & Score $^{3}$ & Cover $(\%)$ & Peptide Sequences & $\begin{array}{l}\text { Sig. Peptide } \\
\text { Number }\end{array}$ & $\begin{array}{l}\text { Func. } \\
\text { Cat. }{ }^{4}\end{array}$ \\
\hline 3 & CLPB1_ARATH & $\begin{array}{l}\text { Chaperone protein } \mathrm{ClpB} 1 \\
\mathrm{OS}=\text { Arabidopsis thaliana }\end{array}$ & 2 & 192 & 11.1 & $\begin{array}{l}\text { TAVVEGLAQR, YRGEFEER, TKNNPVLIGEPGVGK, } \\
\text { KVESASGDTNFQALK, VQLDSQPEEIDNLER, } \\
\text { LIGAPPGYVGHEEGGQLTEAVR }\end{array}$ & 6 & IX \\
\hline 5 & CPNA1_ARATH & $\begin{array}{l}\text { Chaperonin } 60 \text { subunit alpha } 1 \text {, } \\
\text { chloroplastic OS = Arabidopsis thaliana }\end{array}$ & 1 & 189 & 82.82 & VVNDGVTIAR, NVVLDEFGSPK, VGAATETELEDR & 3 & IX \\
\hline 3 & ACOC_CUCMA & $\begin{array}{l}\text { Aconitate hydratase, cytoplasmic } \\
\mathrm{OS}=\text { Cucurbita maxima }\end{array}$ & 6 & 187 & 9.2 & $\begin{array}{l}\text { NFEGR, ILLESAIR, STYESITK, DFNSYGSR, RGNDEVMAR, } \\
\text { TSLAPGSGVVTK, } \\
\text { ATIANMSPEYGATMGFFPVDHVTLQYLK }\end{array}$ & 7 & II \\
\hline 3 & SYA_ARATH & $\begin{array}{l}\text { Alanine--tRNA ligase OS = Arabidopsis } \\
\text { thaliana }\end{array}$ & 1 & 181 & 5.4 & $\begin{array}{l}\text { LTSVLQNK, HVDTGMGFER, ESDGSLKPLPAK, } \\
\text { AFALLSEEGIAK, AVFGEVYPDPVR }\end{array}$ & 5 & IV \\
\hline $6,(7)$ & PRS6A_SOLLC & $\begin{array}{l}26 \mathrm{~S} \text { protease regulatory subunit } 6 \mathrm{~A} \\
\text { homolog } \mathrm{OS}=\text { Solanum lycopersicum }\end{array}$ & 4 & 170 & 8.5 & IIKEELQR, GVLLYGPPGTGK, LAGPQLVQMFIGDGAK & 3 & I \\
\hline 7 & AATM_LUPAN & $\begin{array}{l}\text { Aspartate aminotransferase } \mathrm{P} 2 \text {, } \\
\text { mitochondrial (Fragment) } \mathrm{OS}=\text { Lupinus } \\
\text { angustifolius }\end{array}$ & 1 & 170 & 10.8 & $\begin{array}{l}\text { IADVIQEK, NLGLYAER, LNLGVGAYR, ISLAGLSLAK, } \\
\text { VATVQGLSGTGSLR }\end{array}$ & 5 & I \\
\hline 6 & UGDH_SOYBN & $\begin{array}{l}\text { UDP-glucose 6-dehydrogenase } \\
\text { OS = Glycine } \max \end{array}$ & 1 & 168 & 6.5 & IAILGFAFK, LAANAFLAQR, AADLTYWESAAR & 3 & II \\
\hline 2,8 & ANX4_FRAAN & $\begin{array}{l}\text { Annexin-like protein RJ4 OS = Fragaria } \\
\text { ananassa }\end{array}$ & 1 & 163 & 9.6 & VGTDEDALTR, LLVALVTAYR & 2 & IX \\
\hline 8 & RS4_GOSHI & $\begin{array}{l}\text { 40S ribosomal protein } \mathrm{S} 4 \\
\mathrm{OS}=\text { Gossypium hirsutum }\end{array}$ & 4 & 163 & 22.9 & $\begin{array}{l}\text { LSIIEEAR, LGNVFTIGK, GIPYLNTYDGR, } \\
\text { LGGAFAPKPSSGPHK, TDKTYPAGFMDVVSIPK }\end{array}$ & 5 & $\mathrm{~V}$ \\
\hline $7,(8)$ & RSSA_SOYBN & $\begin{array}{l}\text { 40S ribosomal protein SA OS = Glycine } \\
\max \end{array}$ & 2 & 161 & 19 & $\begin{array}{l}\text { LLILTDPR, YVDIGIPANNK, HTPGTFTNQLQTSFSEPR, } \\
\text { VIVAIENPQDIIVQSARPYGQR }\end{array}$ & 4 & $\mathrm{~V}$ \\
\hline 8 & RAA1D_ARATH & $\begin{array}{l}\text { Ras-related protein RABA1d } \\
\text { OS }=\text { Arabidopsis thaliana }\end{array}$ & 9 & 161 & 26.6 & $\begin{array}{l}\text { AITSAYYR, VVLIGDSGVGK, STIGVEFATR, HSTFENVER, } \\
\text { AQIWDTAGQER }\end{array}$ & 5 & VIII \\
\hline
\end{tabular}


Table 2. Cont.

\begin{tabular}{|c|c|c|c|c|c|c|c|c|}
\hline Fractions ${ }^{1}$ & Protein Accession & Protein Description & Similar $^{2}$ & Score $^{3}$ & Cover $(\%)$ & Peptide Sequences & $\begin{array}{l}\text { Sig. Peptide } \\
\text { Number }\end{array}$ & $\begin{array}{l}\text { Func. } \\
\text { Cat. }^{4}\end{array}$ \\
\hline 8 & RS18_ARATH & $\begin{array}{l}\text { 40S ribosomal protein } \mathrm{S} 18 \\
\mathrm{OS}=\text { Arabidopsis thaliana }\end{array}$ & 1 & 155 & 23.7 & LRDDLER, VLNTNVDGK, IPDWFLNR, YSQVVSNALDMK & 4 & $\mathrm{~V}$ \\
\hline 1 & AVP_VIGRR & $\begin{array}{l}\text { Pyrophosphate-energized vacuolar } \\
\text { membrane proton pump OS = Vigna } \\
\text { radiata } \text { var. } \text { Radiata }\end{array}$ & 1 & 151 & 9.5 & TDALDAAGNTTAAIGK, AAVIGDTIGDPLKDTSGPSLNILIK & 2 & VI \\
\hline 5 & ILV5_ARATH & $\begin{array}{l}\text { Ketol-acid reductoisomerase, } \\
\text { chloroplastic OS = Arabidopsis thaliana }\end{array}$ & 1 & 150 & 27.45 & SDIVVK, SVVLAGR, QIGVIGWGSQGPAQAQNLR & 3 & I \\
\hline 7 & AATC_DAUCA & $\begin{array}{l}\text { Aspartate aminotransferase, cytoplasmic } \\
\text { OS = Daucus carota }\end{array}$ & 2 & 149 & 10.4 & ISMAGLSSR, LNLGVGAYR, LIFGADSPAIQENR & 3 & I \\
\hline 8 & RL13_TOBAC & $\begin{array}{l}\text { 60S ribosomal protein } \mathrm{L} 13 \\
\mathrm{OS}=\text { Nicotiana tabacum }\end{array}$ & 1 & 149 & 23.3 & $\begin{array}{l}\text { GFSLEELK, TWFNQPAR, SLEGLQTNVQR, } \\
\text { KLAPTIGIAVDHR }\end{array}$ & 4 & $\mathrm{~V}$ \\
\hline 5 & ACLB1_ORYSJ & $\begin{array}{l}\text { ATP-citrate synthase beta chain protein } 1 \\
\text { OS }=\text { Oryza sativa subsp. Japonica }\end{array}$ & 1 & 148 & 35.6 & $\begin{array}{l}\text { FNNIPQVK, FGGAIDDAAR, SEVQFGHAGAK, } \\
\text { SIGLIGHTFDQKR, VVAIIAEGVPESDTK }\end{array}$ & 5 & I \\
\hline 2,(3) & COPA1_ARATH & $\begin{array}{l}\text { Coatomer subunit alpha-1 } \\
\text { OS = Arabidopsis thaliana }\end{array}$ & 3 & 147 & 4.4 & $\begin{array}{l}\text { VWDIGALR, YVLEGHDR, AWEVDTLR, VVIFDLQQR, } \\
\text { TLDVPIYITK, QDIIVSNSEDK }\end{array}$ & 6 & VI \\
\hline 6 & CATA2_RICCO & $\begin{array}{l}\text { Catalase isozyme } 2 \mathrm{OS}=\text { Ricinus } \\
\text { communis }\end{array}$ & 2 & 146 & 9.3 & FSTVIHER, APGVQTPVIVR, EGNFDIVGNNFPVFFIR & 3 & IX \\
\hline 8 & RAN3_ORYSI & $\begin{array}{l}\text { GTP-binding nuclear protein Ran-3 } \\
\text { OS = Oryza sativa subsp. Indica }\end{array}$ & 1 & 145 & 14.2 & HITGEFEK,NLQYYEISAK, SNYNFEKPFLYLAR & 3 & $\mathrm{III} / \mathrm{VI}$ \\
\hline 6 & MDAR_SOLLC & $\begin{array}{l}\text { Monodehydroascorbate reductase } \\
\text { OS = Solanum lycopersicum }\end{array}$ & 1 & 139 & 12.5 & $\begin{array}{l}\text { AYLFPEGAAR, LSDFGVQGADSK, } \\
\text { IVGAFLESGSPEENKAIAK }\end{array}$ & 3 & IX \\
\hline $6,(1)$ & RL3_ORYSJ & $\begin{array}{l}\text { 60S ribosomal protein } \mathrm{L} 3 \mathrm{OS}=\text { Oryza } \\
\text { sativa subsp. Japonica }\end{array}$ & 4 & 138 & 9.3 & VIAHTQIR, HGSLGFLPR, LALEEIKLK, GKGYEGVVTR & 4 & $\mathrm{~V}$ \\
\hline
\end{tabular}


Table 2. Cont

\begin{tabular}{|c|c|c|c|c|c|c|c|c|}
\hline Fractions ${ }^{1}$ & Protein Accession & Protein Description & Similar $^{2}$ & Score $^{3}$ & Cover $(\%)$ & Peptide Sequences & $\begin{array}{l}\text { Sig. Peptide } \\
\text { Number }\end{array}$ & $\begin{array}{l}\text { Func. } \\
\text { Cat. }^{4}\end{array}$ \\
\hline 5 & PMGI_RICCO & $\begin{array}{c}\text { 2,3-bisphosphoglycerate-independent } \\
\text { phosphoglycerate mutase OS = Ricinus } \\
\text { communis }\end{array}$ & 4 & 136 & 43.5 & $\begin{array}{l}\text { ARDAILSGK, LVDLALASGK, LDQLQLLLK, } \\
\text { AHGTAVGLPTEDDMGNSEVGHNALGAGR }\end{array}$ & 4 & II \\
\hline 5 & RUBA_RICCO & $\begin{array}{l}\text { RuBisCO large subunit-binding protein } \\
\text { subunit alpha (Fragment) OS = Ricinus } \\
\text { communis }\end{array}$ & 2 & 134 & 71.19 & NVVLDEFGSPK, VGAATETELEDR, LGLLSVTSGANPVSIK & 3 & I \\
\hline 7 & RL4_PRUAR & $\begin{array}{l}60 \mathrm{~S} \text { ribosomal protein } \mathrm{L} 4 \mathrm{OS}=\text { Prunus } \\
\text { armeniaca }\end{array}$ & 1 & 134 & 14.5 & AGHQTSAESWGTGR, YAVVSAIAASAVPSLVLAR & 2 & $\mathrm{~V}$ \\
\hline 5 & G6PI_SPIOL & $\begin{array}{c}\text { Glucose-6-phosphate isomerase, cytosolic } \\
\text { OS = Spinacia oleracea }\end{array}$ & 2 & 131 & 27 & SQQPVYLK, FLANVDPIDVAK, TFTTAETMLNAR & 3 & II \\
\hline 8 & RS8_MAIZE & 40S ribosomal protein $\mathrm{S} 8 \mathrm{OS}=$ Zea mays & 1 & 130 & 21.7 & LDTGNYSWGSEAVTR, ILDVVYNASNNELVR & 2 & $\mathrm{~V}$ \\
\hline 8 & RL11_MEDSA & $\begin{array}{l}\text { 60S ribosomal protein } \mathrm{L} 11 \\
\mathrm{OS}=\text { Medicago sativa }\end{array}$ & 1 & 129 & 17.7 & YEGVILNK,AMQLLESGLK, VLEQLSGQTPVFSK & 3 & $\mathrm{~V}$ \\
\hline $8,(7)$ & H4_ARATH & Histone $\mathrm{H} 4 \mathrm{OS}=$ Arabidopsis thaliana & 2 & 128 & 46.6 & TLYGFGG, IFLENVIR, DAVTYTEHAR, ISGLIYEETR & 4 & VII \\
\hline 5 & TCPE_ARATH & $\begin{array}{c}\text { T-complex protein } 1 \text { subunit epsilon } \\
\text { OS }=\text { Arabidopsis thaliana }\end{array}$ & 1 & 123 & 73.41 & IAEGYEMASR, QQQILLATQVVK & 2 & $\mathrm{~V}$ \\
\hline 5 & TCPA_ARATH & $\begin{array}{c}\text { T-complex protein } 1 \text { subunit alpha } \\
\mathrm{OS}=\text { Arabidopsis thaliana }\end{array}$ & 1 & 119 & 71.23 & YFVEAGAIAVR, NKIHPTSIISGYR & 2 & $\mathrm{~V}$ \\
\hline 4 & TKTC_SPIOL & $\begin{array}{c}\text { Transketolase, chloroplastic } \\
\text { OS = Spinacia oleracea }\end{array}$ & 4 & 118 & 6.1 & $\begin{array}{c}\text { FLAIDAVEK, ALPTYTPETPGDATR, } \\
\text { VIPGLLGGSADLASSNMTLLK }\end{array}$ & 3 & II \\
\hline 8 & TPIS_MAIZE & $\begin{array}{l}\text { Triosephosphate isomerase, cytosolic } \\
\qquad \mathrm{OS}=\text { Zea mays }\end{array}$ & 1 & 117 & 11.9 & FFVGGNWK,VAYALSQGLK, VIACVGETLEQR & 3 & VII \\
\hline 8 & PROF3_ARATH & Profilin-3 OS = Arabidopsis thaliana & 2 & 117 & 17.2 & LGDYLLEQGL, YMVIQGEPGAVIR & 2 & VII \\
\hline 8 & RS92_ARATH & $\begin{array}{l}\text { 40S ribosomal protein } \mathrm{S} 9-2 \\
\mathrm{OS}=\text { Arabidopsis thaliana }\end{array}$ & 1 & 115 & 19.3 & $\begin{array}{c}\text { LVGEYGLR, ERLDAELK, RPYEKER, } \\
\text { RLQTIVFK,IFEGEALLR }\end{array}$ & 5 & $\mathrm{~V}$ \\
\hline
\end{tabular}


Table 2. Cont.

\begin{tabular}{|c|c|c|c|c|c|c|c|c|}
\hline Fractions ${ }^{1}$ & Protein Accession & Protein Description & Similar $^{2}$ & Score $^{3}$ & Cover $(\%)$ & Peptide Sequences & $\begin{array}{l}\text { Sig. Peptide } \\
\text { Number }\end{array}$ & $\begin{array}{l}\text { Func. } \\
\text { Cat. }{ }^{4}\end{array}$ \\
\hline 6 & VATB1_ARATH & $\begin{array}{l}\text { V-type proton ATPase subunit B1 } \\
\text { OS = Arabidopsis thaliana }\end{array}$ & 1 & 115 & 10.5 & YQEIVNIR, TVSGVAGPLVILDK, QIYPPINVLPSLSR & 3 & VI \\
\hline 6 & ERF1X_ARATH & $\begin{array}{l}\text { Eukaryotic peptide chain release factor } \\
\text { subunit 1-1 OS = Arabidopsis thaliana }\end{array}$ & 1 & 113 & 9.9 & GFGGIGGILR, QSVLGAITSAQQR & 2 & $\mathrm{~V}$ \\
\hline 5 & HSP7M_PHAVU & $\begin{array}{l}\text { Heat shock } 70 \mathrm{kDa} \text { protein, mitochondrial } \\
\mathrm{OS}=\text { Phaseolus vulgaris }\end{array}$ & 3 & 111 & 24.87 & $\begin{array}{l}\text { HLNITLTR, VIENSEGAR, TTPSVVAFNQK, } \\
\text { SSGGLSEDEIEK }\end{array}$ & 4 & IX \\
\hline 8 & ANXD1_ARATH & Annexin D1 OS = Arabidopsis thaliana & 1 & 110 & 5 & AQINATFNR, SKAQINATFNR & 2 & IX \\
\hline 8 & RS16_FRIAG & $\begin{array}{l}\text { 40S ribosomal protein } \mathrm{S} 16 \\
\mathrm{OS}=\text { Fritillaria agrestis }\end{array}$ & 3 & 109 & 13.8 & ALVAYYQK, AFEPILLLGR, YKAFEPILLLGR & 3 & $\mathrm{~V}$ \\
\hline 8 & RS5_CICAR & $\begin{array}{l}40 \mathrm{~S} \text { ribosomal protein } \mathrm{S} 5 \text { (Fragment) OS } \\
=\text { Cicer arietinum }\end{array}$ & 1 & 108 & 15.7 & IGSAGVVRR, GSSNSYAIK, VNQAIYLLTTGAR & 3 & $\mathrm{~V}$ \\
\hline 8 & ARF_VIGUN & $\begin{array}{l}\text { ADP-ribosylation factor OS = Vigna } \\
\text { unguiculata }\end{array}$ & 1 & 104 & 28.7 & ILMVGLDAAGK,NISFTVWDVGGQDK & 2 & VIII \\
\hline 4 & SYGM1_ARATH & $\begin{array}{l}\text { Glycine--tRNA ligase } 1, \text { mitochondrial } \\
\text { OS = Arabidopsis thaliana }\end{array}$ & 1 & 103 & 5.1 & LFYIPSFK, VFTPSVIEPSFGIGR & 2 & IV/VI \\
\hline 7 & RGP1_ORYSJ & $\begin{array}{l}\text { UDP-arabinopyranose mutase } 1 \\
\text { OS }=\text { Oryza sativa subsp. Japonica }\end{array}$ & 1 & 101 & 6.9 & ILGPK, ASNPFVNLK, ASNPFVNLKK, YVDAVMTVPK & 4 & I \\
\hline 3 & HSP7O_ARATH & $\begin{array}{l}\text { Heat shock } 70 \mathrm{kDa} \text { protein } 14 \\
\text { OS }=\text { Arabidopsis thaliana }\end{array}$ & 1 & 101 & 5.1 & ILSHAFDR, NAVESYVYDMR, AVLDAATIAGLHPLR & 3 & IX \\
\hline 8 & RS15A_DAUCA & $\begin{array}{l}\text { 40S ribosomal protein } \mathrm{S} 15 \mathrm{a} \mathrm{OS}=\text { Daucus } \\
\text { carota }\end{array}$ & 1 & 100 & 29.2 & VSVLNDALK, HGYIGEFEYVDDHR & 2 & $\mathrm{~V}$ \\
\hline 8 & RS61_ARATH & $\begin{array}{l}\text { 40S ribosomal protein } \mathrm{S} 6-1 \\
\mathrm{OS}=\text { Arabidopsis thaliana }\end{array}$ & 2 & 100 & 18 & $\begin{array}{l}\text { LVTPLTLQR,KGENDLPGLTDTEKPR,ISQEVSGDALGEEFK } \\
\text { GYVFK }\end{array}$ & 3 & $\mathrm{~V}$ \\
\hline 6 & ACCC2_POPTR & $\begin{array}{l}\text { Biotin carboxylase } 2 \text {, chloroplastic } \\
\text { OS = Populus trichocarpa }\end{array}$ & 1 & 97 & 7.8 & LLEEAPSPALTPELR, ALDDTVITGVPTTIDYHK & 2 & I \\
\hline
\end{tabular}


Table 2. Cont.

\begin{tabular}{|c|c|c|c|c|c|c|c|c|}
\hline Fractions $^{1}$ & Protein Accession & Protein Description & Similar $^{2}$ & Score $^{3}$ & Cover $(\%)$ & Peptide Sequences & $\begin{array}{l}\text { Sig. Peptide } \\
\text { Number }\end{array}$ & $\begin{array}{l}\text { Func. } \\
\text { Cat. }^{4}\end{array}$ \\
\hline 8 & RLA2_PARAR & $\begin{array}{l}60 \mathrm{~S} \text { acidic ribosomal protein } \mathrm{P} 2 \\
\mathrm{OS}=\text { Parthenium argentatum }\end{array}$ & 1 & 97 & 10.5 & DITELIASGR, GKDITELIASGR & 2 & $\mathrm{~V}$ \\
\hline 8 & RS33_ARATH & $\begin{array}{l}\text { 40S ribosomal protein } \mathrm{S} 3-3 \\
\mathrm{OS}=\text { Arabidopsis thaliana }\end{array}$ & 3 & 96 & 10.9 & ELAEDGYSGVEVR, FKFPQDSVELYAEK & 2 & $\mathrm{~V}$ \\
\hline 5 & KPYC_SOYBN & $\begin{array}{l}\text { Pyruvate kinase, cytosolic isozyme } \\
\text { OS = Glycine } \max \end{array}$ & 1 & 94 & 55.66 & KGSDLVNVR, STPLPMSPLESLASSAVR & 2 & II \\
\hline 7 & GMD1_ARATH & $\begin{array}{l}\text { GDP-mannose } 4,6 \text { dehydratase } 1 \\
\text { OS = Arabidopsis thaliana }\end{array}$ & 2 & 93 & 5 & RGENFVTR, LFLGNIQASR & 2 & II \\
\hline 4 & HSP7S_SPIOL & $\begin{array}{l}\text { Stromal } 70 \mathrm{kDa} \text { heat shock-related } \\
\text { protein, chloroplastic (Fragment) } \\
\text { OS = Spinacia oleracea }\end{array}$ & 2 & 93 & 5.3 & HIETTLTR, IINEPTAASLAYGFEK & 2 & IX \\
\hline 6 & EF1G2_ORYSJ & $\begin{array}{l}\text { Elongation factor 1-gamma } 2 \\
\text { OS = Oryza sativa subsp. Japonica }\end{array}$ & 3 & 93 & 16.7 & $\begin{array}{l}\text { EVAIK, LYSNTK, NPLDLLPPSK, MILDEWKR, } \\
\text { SFTSEFPHVER }\end{array}$ & 5 & $\mathrm{~V}$ \\
\hline 8 & RLA0_LUPLU & $\begin{array}{l}\text { 60S acidic ribosomal protein } \mathrm{P} 0 \\
\mathrm{OS}=\text { Lupinus luteus }\end{array}$ & 1 & 90 & 9.9 & EYLKDPSK,VGSSEAALLAK & 2 & $\mathrm{~V}$ \\
\hline 7 & GCST_PEA & $\begin{array}{l}\text { Aminomethyltransferase, mitochondrial } \\
\text { OS = Pisum sativum }\end{array}$ & 1 & 89 & 8.3 & GGAIDDSVITK, TGYTGEDGFEISVPSEHGVELAK & 2 & I \\
\hline 8 & APX1_ORYSJ & $\begin{array}{l}\text { L-ascorbate peroxidase } 1 \text {, cytosolic } \\
\text { OS }=\text { Oryza sativa subsp. Japonica }\end{array}$ & 1 & 89 & 15.2 & TGGPFGTMK, LSELGFADA, ALLSDPAFRPLVEK & 3 & IX \\
\hline 8 & RS193_ARATH & $\begin{array}{l}\text { 40S ribosomal protein } \mathrm{S} 19-3 \\
\mathrm{OS}=\text { Arabidopsis thaliana }\end{array}$ & 1 & 88 & 23.1 & AYAAHLKR, TVKDVSPHEFVK, ELAPYDPDWYYIR & 3 & $\mathrm{~V}$ \\
\hline $1,(2)$ & RPN1A_ARATH & $\begin{array}{l}\text { 26S proteasome non-ATPase regulatory } \\
\text { subunit } 21 \mathrm{~A} \mathrm{OS}=\text { Arabidopsis thaliana }\end{array}$ & 3 & 87 & 5.5 & VGQAVDVVGQAGRPK, NLAGEIAQEYTKR & 2 & $\mathrm{I}$ \\
\hline $4,(3)$ & PPDK_FLABR & $\begin{array}{l}\text { Pyruvate, phosphate dikinase, } \\
\text { chloroplastic OS = Flaveria brownii }\end{array}$ & 8 & 87 & 2.9 & SDFEGIFR, AALIADEIAK, AMDGLPVTIR & 3 & II \\
\hline
\end{tabular}


Table 2. Cont.

\begin{tabular}{|c|c|c|c|c|c|c|c|c|}
\hline Fractions ${ }^{1}$ & Protein Accession & Protein Description & Similar $^{2}$ & Score $^{3}$ & Cover $(\%)$ & Peptide Sequences & $\begin{array}{l}\text { Sig. Peptide } \\
\text { Number }\end{array}$ & $\begin{array}{l}\text { Func. } \\
\text { Cat. }{ }^{4}\end{array}$ \\
\hline 8 & RS13_PEA & $\begin{array}{l}40 \mathrm{~S} \text { ribosomal protein } \mathrm{S} 13 \mathrm{OS}=\text { Pisum } \\
\text { sativum }\end{array}$ & 1 & 87 & 25.8 & $\begin{array}{l}\text { DSHGIAQVK, GLTPSQIGVILR, KGLTPSQIGVILR, } \\
\text { AHGLAPEIPEDLYHLIK }\end{array}$ & 4 & $\mathrm{~V}$ \\
\hline 8 & RS14_CHLRE & $\begin{array}{l}\text { 40S ribosomal protein } \mathrm{S} 14 \\
\mathrm{OS}=\text { Chlamydomonas reinhardtii }\end{array}$ & 1 & 85 & 18.3 & TPGPGAQSALR, IEDVTPIPTDSTRR & 2 & $\mathrm{~V}$ \\
\hline 6 & VATB2_GOSHI & $\begin{array}{l}\text { V-type proton ATPase subunit B } 2 \\
\text { (Fragment) OS = Gossypium hirsutum }\end{array}$ & 1 & 84 & 10.1 & FVTQGAYDTR,QIYPPINVLPSLSR & 2 & VI \\
\hline $8,(5)$ & CYPH_MAIZE & $\begin{array}{l}\text { Peptidyl-prolyl cis-trans isomerase } \\
\text { OS = Zea mays }\end{array}$ & 3 & 83 & 16.3 & SGKPLHYK, VFFDMTVGGAPAGR & 2 & $\mathrm{~V}$ \\
\hline 8 & NDK1_ARATH & $\begin{array}{l}\text { Nucleoside diphosphate kinase } 1 \\
\text { OS = Arabidopsis thaliana }\end{array}$ & 1 & 82 & 9.4 & NVIHGSDSVESAR, NVIHGSDSVESARK & 2 & I \\
\hline 7 & GLN11_ORYSJ & $\begin{array}{l}\text { Glutamine synthetase cytosolic isozyme } \\
1-1 \text { OS = Oryza sativa subsp. Japonica }\end{array}$ & 1 & 79 & 7.6 & DIVDSHYK, HKEHISAYGEGNER & 2 & I \\
\hline 7 & SERC_SPIOL & $\begin{array}{l}\text { Phosphoserine aminotransferase, } \\
\text { chloroplastic OS = Spinacia oleracea }\end{array}$ & 1 & 79 & 5.3 & FGLIYAGAQK,NVGPSGVTIVIVR & 2 & I \\
\hline 7 & PDI21_ARATH & $\begin{array}{l}\text { Protein disulfide-isomerase like } 2-1 \\
\text { OS = Arabidopsis thaliana }\end{array}$ & 1 & 78 & 8.9 & KLAPEYEK, YGVSGFPTLK, YGVSGYPTIQWFPK & 3 & $\mathrm{~V}$ \\
\hline 8 & RS254_ARATH & $\begin{array}{l}\text { 40S ribosomal protein } \mathrm{S} 25-4 \\
\mathrm{OS}=\text { Arabidopsis thaliana }\end{array}$ & 2 & 76 & 29.6 & LITPSILSDR, MVAAHSSQQIYTR & 2 & $\mathrm{~V}$ \\
\hline 6 & IDHC_TOBAC & $\begin{array}{l}\text { Isocitrate dehydrogenase [NADP] } \\
\text { OS = Nicotiana tabacum }\end{array}$ & 2 & 75 & 7.5 & HAFGDQYR,DLALIIHGSK, TIEAEAAHGTVTR & 3 & II \\
\hline 6 & OPD22_ARATH & $\begin{array}{l}\text { Dihydrolipoyllysine-residue } \\
\text { acetyltransferase component } 2 \text { of pyruvate } \\
\text { dehydrogenase complex, mitochondrial } \\
\text { OS = Arabidopsis thaliana }\end{array}$ & 1 & 73 & 3.9 & ISVNDLVIK, VIDGAIGAEWLK & 2 & II \\
\hline 8 & RL40A_ARATH & $\begin{array}{l}\text { Ubiquitin-60S ribosomal protein } \mathrm{L} 40-1 \\
\text { OS = Arabidopsis thaliana }\end{array}$ & 1 & 70 & 45.3 & ESTLHLVLR, TITLEVESSDTIDNVK & 2 & $\mathrm{~V}$ \\
\hline
\end{tabular}


Table 2. Cont.

\begin{tabular}{|c|c|c|c|c|c|c|c|c|}
\hline Fractions ${ }^{1}$ & Protein Accession & Protein Description & Similar $^{2}$ & Score $^{3}$ & Cover $(\%)$ & Peptide Sequences & $\begin{array}{l}\text { Sig. Peptide } \\
\text { Number }\end{array}$ & $\begin{array}{l}\text { Func. } \\
\text { Cat. }{ }^{4}\end{array}$ \\
\hline 8 & RL24_PRUAV & $\begin{array}{l}60 \mathrm{~S} \text { ribosomal protein } \mathrm{L} 24 \mathrm{OS}=\text { Prunus } \\
\text { avium }\end{array}$ & 1 & 69 & 7 & SIVGATLEVIQK, SIVGATLEVIQKR & 2 & $\mathrm{~V}$ \\
\hline $7,(5)$ & SAPK6_ORYSJ & $\begin{array}{l}\text { Serine/threonine-protein kinase SAPK6 } \\
\text { OS = Oryza sativa subsp. Japonica }\end{array}$ & 2 & 68 & 7.4 & DIGSGNFGVAR,STVGTPAYIAPEVLSR & 2 & III \\
\hline 6 & GME2_ORYSJ & $\begin{array}{l}\text { GDP-mannose 3,5-epimerase } 2 \\
\text { OS = Oryza sativa subsp. Japonica }\end{array}$ & 1 & 67 & 7 & NSDNTLIKEK, ISITGAGGFIASHIAR & 2 & II \\
\hline 8 & EF1D1_ORYSJ & $\begin{array}{l}\text { Elongation factor } 1 \text {-delta } 1 \mathrm{OS}=\text { Oryza } \\
\text { sativa subsp. Japonica }\end{array}$ & 2 & 66 & 7.9 & LVPVGYGIK,KLDEYLLTR & 2 & $\mathrm{~V}$ \\
\hline 8 & IF5A1_ARATH & $\begin{array}{l}\text { Eukaryotic translation initiation factor } \\
\text { 5A-1 OS = Arabidopsis thaliana }\end{array}$ & 1 & 64 & 12 & VVEVSTSK,TYPQQAGTIR, TYPQQAGTIRK & 3 & $\mathrm{~V}$ \\
\hline 8 & H2B11_ARATH & $\begin{array}{l}\text { Histone H2B.11 OS = Arabidopsis } \\
\text { thaliana }\end{array}$ & 1 & 62 & 30 & LVLPGELAK,QVHPDIGISSK, YNKKPTITSR & 3 & VII \\
\hline 8 & PSA3_ARATH & $\begin{array}{l}\text { Proteasome subunit alpha type- } 3 \\
\text { OS = Arabidopsis thaliana }\end{array}$ & 1 & 60 & 7.6 & VFQIEYAAK, VPDDLLEEAK & 2 & I \\
\hline 7 & AAT3_ARATH & $\begin{array}{l}\text { Aspartate aminotransferase, chloroplastic } \\
\text { OS = Arabidopsis thaliana }\end{array}$ & 1 & 60 & 4.9 & LNLGVGAYR,TEEGKPLVLNVVR & 2 & I \\
\hline 1 & PDR4_ORYSJ & $\begin{array}{l}\text { Pleiotropic drug resistance protein } 4 \mathrm{OS}= \\
\text { Oryza sativa subsp. Japonica }\end{array}$ & 1 & 60 & 1.5 & TTLLLALAGK, VTTGEMLVGPAR & 2 & IX \\
\hline $2,(8)$ & UBQ12_ARATH & $\begin{array}{l}\text { Polyubiquitin } 12 \mathrm{OS}=\text { Arabidopsis } \\
\text { thaliana }\end{array}$ & 3 & 60 & 23.9 & $\begin{array}{l}\text { MQIFLKTLTGK, IQDKEGIPPDQQR, } \\
\text { TITLEVESSDTIDNVK }\end{array}$ & 3 & $\mathrm{~V}$ \\
\hline $2,(1)$ & UBIQ_AVESA & Ubiquitin $\mathrm{OS}=$ Avena sativa & 1 & 60 & 57.9 & TLADYNIQK, IQDKEGIPPDQQR, TITLEVESSDTIDNVK & 3 & $\mathrm{~V}$ \\
\hline $5,(1)$ & DIM_PEA & $\begin{array}{l}\text { Delta(24)-sterol reductase OS = Pisum } \\
\text { sativum }\end{array}$ & 2 & 59 & 45.72 & NILDIDKER, SDLEAPLRPK & 2 & I \\
\hline 8 & HSP11_PEA & $\begin{array}{l}18.1 \mathrm{kDa} \text { class } \mathrm{I} \text { heat shock protein } \\
\text { OS = Pisum sativum }\end{array}$ & 2 & 56 & 8.9 & SIEISG, VLQISGER & 2 & IX \\
\hline
\end{tabular}


Table 2. Cont.

\begin{tabular}{|c|c|c|c|c|c|c|c|c|}
\hline Fractions ${ }^{1}$ & Protein Accession & Protein Description & Similar $^{2}$ & Score $^{3}$ & Cover $(\%)$ & Peptide Sequences & $\begin{array}{l}\text { Sig. Peptide } \\
\text { Number }\end{array}$ & $\begin{array}{l}\text { Func. } \\
\text { Cat. }{ }^{4}\end{array}$ \\
\hline 6 & MPPA_SOLTU & $\begin{array}{l}\text { Mitochondrial-processing peptidase } \\
\text { subunit alpha OS = Solanum tuberosum }\end{array}$ & 1 & 52 & 3.4 & QLLTYGER, MVASEDIGR & 2 & I \\
\hline 8 & RL17_MAIZE & $\begin{array}{l}60 \mathrm{~S} \text { ribosomal protein } \mathrm{L} 17 \mathrm{OS}=\mathrm{Zea} \\
\text { mays }\end{array}$ & 1 & 52 & 10.5 & NAESNADVK, YLEDVIAHK & 2 & $\mathrm{~V}$ \\
\hline 8 & RL51_ARATH & $\begin{array}{l}\text { 60S ribosomal protein } \mathrm{L} 5-1 \\
\mathrm{OS}=\text { Arabidopsis thaliana }\end{array}$ & 2 & 52 & 9.3 & VFGALK, KLTYEER, GALDGGLDIPHSDKR & 3 & $\mathrm{~V}$ \\
\hline 3 & PHSL1_SOLTU & $\begin{array}{l}\text { Alpha-1,4 glucan phosphorylase L-1 } \\
\text { isozyme, chloroplastic/amyloplastic } \\
\text { OS = Solanum tuberosum }\end{array}$ & 1 & 50 & 1.8 & NDVSYPIK, AFATYVQAK & 2 & II \\
\hline 6 & PRS4A_ARATH & $\begin{array}{l}26 \mathrm{~S} \text { proteasome regulatory subunit } 4 \\
\text { homolog A OS = Arabidopsis thaliana }\end{array}$ & 1 & 49 & 9.5 & VVGSELIQK, GVILYGEPGTGK & 2 & II \\
\hline 8 & YPTC1_CHLRE & $\begin{array}{l}\text { GTP-binding protein YPTC1 } \\
\text { OS }=\text { Chlamydomonas reinhardtii }\end{array}$ & 2 & 49 & 17.2 & TITSSYYR,LLLIGDSGVGK & 2 & III/VI \\
\hline 4 & HSP7G_ARATH & $\begin{array}{l}\text { Heat shock } 70 \mathrm{kDa} \text { protein } 7 \text {, } \\
\text { chloroplastic } \mathrm{OS}=\text { Arabidopsis thaliana }\end{array}$ & 1 & 47 & 9.5 & HIETTLTR, TTPSVVAYTK, QAVVNPENTFFSVKR & 3 & IX \\
\hline 8 & SODM_HEVBR & $\begin{array}{l}\text { Superoxide dismutase }[\mathrm{Mn}] \\
\text { mitochondrial } \mathrm{OS}=\text { Hevea brasiliensis }\end{array}$ & 1 & 46 & 11.2 & HHQTYITNYNK, LVVETTANQDPLVTK & 2 & IX \\
\hline 5 & CALX2_ARATH & $\begin{array}{l}\text { Calnexin homolog } 2 \mathrm{OS}=\text { Arabidopsis } \\
\text { thaliana }\end{array}$ & 2 & 45 & 30.3 & NPAYK, SEGHDDYGLLVSEK & 2 & $\mathrm{~V}$ \\
\hline 8 & RS30_ARATH & $\begin{array}{l}\text { 40S ribosomal protein } \mathrm{S} 30 \\
\mathrm{OS}=\text { Arabidopsis thaliana }\end{array}$ & 1 & 44 & 30.6 & GKVHGSLAR,FVTAVVGFGK & 2 & $\mathrm{~V}$ \\
\hline 8 & RL7A1_ARATH & $\begin{array}{l}\text { 60S ribosomal protein } \mathrm{L} 7 \mathrm{a}-1 \\
\mathrm{OS}=\text { Arabidopsis thaliana }\end{array}$ & 1 & 44 & 9.3 & TLDKNLATSLFK, LKVPPALNQFTK & 2 & $\mathrm{~V}$ \\
\hline 7 & METK4_POPTR & $\begin{array}{l}\text { S-adenosylmethionine synthase } 4 \\
\text { OS = Populus trichocarpa }\end{array}$ & 1 & 42 & 12.3 & FVIGGPHGDAGLTGR,VLVNIEQQSPDIAQGVHGHLTK & 2 & I \\
\hline
\end{tabular}


Table 2. Cont.

\begin{tabular}{|c|c|c|c|c|c|c|c|c|}
\hline Fractions ${ }^{1}$ & Protein Accession & Protein Description & Similar $^{2}$ & Score $^{3}$ & Cover $(\%)$ & Peptide Sequences & $\begin{array}{l}\text { Sig. Peptide } \\
\text { Number }\end{array}$ & $\begin{array}{l}\text { Func. } \\
\text { Cat. }^{4}\end{array}$ \\
\hline 8 & RL18A_CASSA & $\begin{array}{l}\text { 60S ribosomal protein } \mathrm{L} 18 \mathrm{a} \\
\mathrm{OS}=\text { Castanea sativa }\end{array}$ & 1 & 41 & 9.6 & ASRPNLFM, FHQYQVVGR & 2 & $\mathrm{~V}$ \\
\hline 7 & EFTM_ARATH & $\begin{array}{l}\text { Elongation factor } \mathrm{Tu} \text {, mitochondrial } \\
\mathrm{OS}=\text { Arabidopsis thaliana }\end{array}$ & 1 & 41 & 9.7 & QAILK,VLAEEGKAK, GITIATAHVEYETAKR & 3 & $\mathrm{~V}$ \\
\hline 1 & CALSB_ARATH & $\begin{array}{c}\text { Callose synthase } 11 \text { OS }=\text { Arabidopsis } \\
\text { thaliana }\end{array}$ & 1 & 38 & 1.5 & ILFNEAFSR, LGEGKPENQNHALIFTR & 2 & IX \\
\hline 3 & APBLB_ARATH & $\begin{array}{l}\text { Beta-adaptin-like protein B } \\
\mathrm{OS}=\text { Arabidopsis thaliana }\end{array}$ & 1 & 27 & 2 & EAENIVER, DSQDPNPLIR & 2 & VII \\
\hline
\end{tabular}

${ }^{1}$ Fraction corresponding to slice of the 1-D gel in which matches for the protein were found. Numbers in parenthesis indicate fractions where additional similar matches $\left(\mathrm{see}^{2}\right.$ ) were found. ${ }^{2}$ Number of protein matches of high taxonomical and sequence similarity grouped together with this match. (Match displayed was the top-scored one.) ${ }^{3}$ MASCOT score. ${ }^{4}$ I: metabolism, II: energy, III: cell growth/division, IV: transcription, V: protein synthesis/destination, VI: transporters, VII: cell structure, VIII: signal transduction, IX: disease/stress defense, and X: unclassified. 


\subsection{Comparative Analysis of Lotus Seed (Immature Endosperm, Mature Endosperm, and}

Embryo) Proteins

As is to be expected, there were many proteins in common found among the immature endosperm and embryo tissues, as well as with the mature endosperm previously analyzed [17]. Amongst all three seed tissues, a total of $206 \mathrm{nr}$ proteins were identified against the plant database (Figure 3). Of these, $31(15 \%)$ were common to all three tissues, $40(19 \%)$ were unique to the immature endosperm, and 65 (32\%) were unique to the embryo; only 14 (7\%) were exclusively found in the mature endosperm. To note, the larger share of embryo-only proteins is a consequence of the embryo tissue being much more involved in plant metabolism, and therefore is expected to express a larger number of functional proteins than the endosperm, which, especially in its mature phase, has nutrient storage as its primary function. The immature endosperm, as a developing tissue, also expresses a larger number of proteins than its mature form, and also shares a significant number of proteins with the embryo-35 (17\%) of the identified ones. Common proteins between mature and immature endosperm only amounted to $5 \%$ of the identified ones (same as for between the mature endosperm and embryo). Although, considering that both immature endosperm and immature embryo are much softer and with a higher water content than their mature stages, there is a possibility that some of the proteins in common with the embryo identified in the immature endosperm might have originated from the embryo and diffused through the endosperm, despite the care taken to remove embryo fragments and the endosperm immediately around them in the sample preparation.

(a)

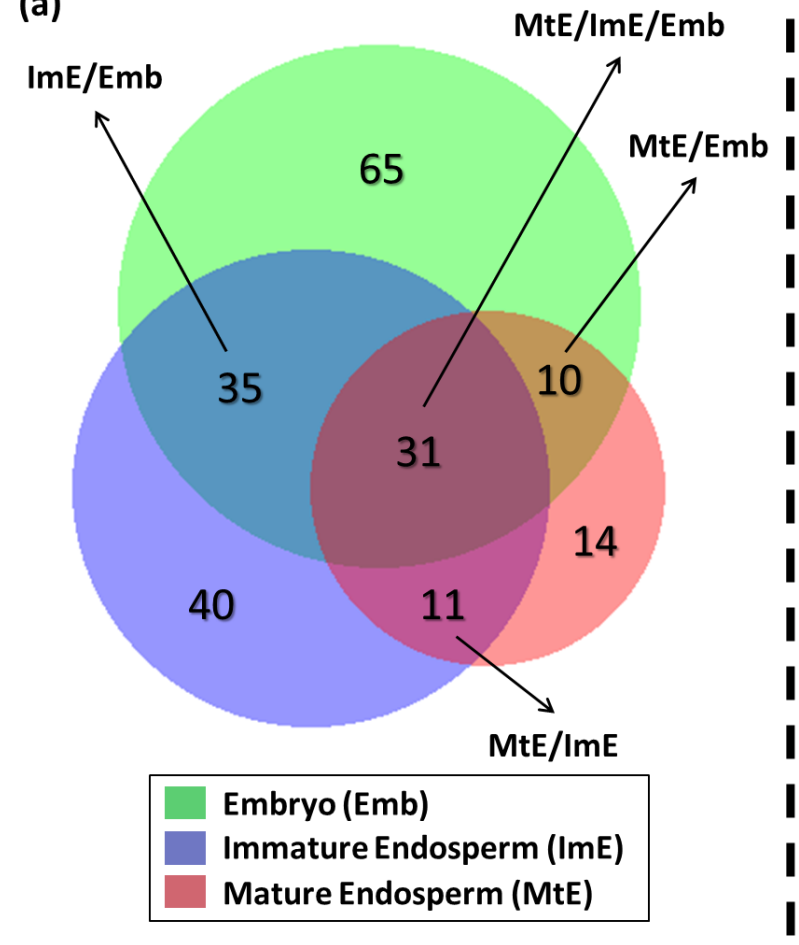

(b)

PROTEINS IDENTIFIED FOR EACH

INDIVIDUAL TISSUE

\begin{tabular}{|lll} 
& Total & NR \\
Immature Endosperm & 333 & 122 \\
Embryo & 373 & 141 \\
Mature Endosperm* & $171^{*}$ & $66^{*}$
\end{tabular}

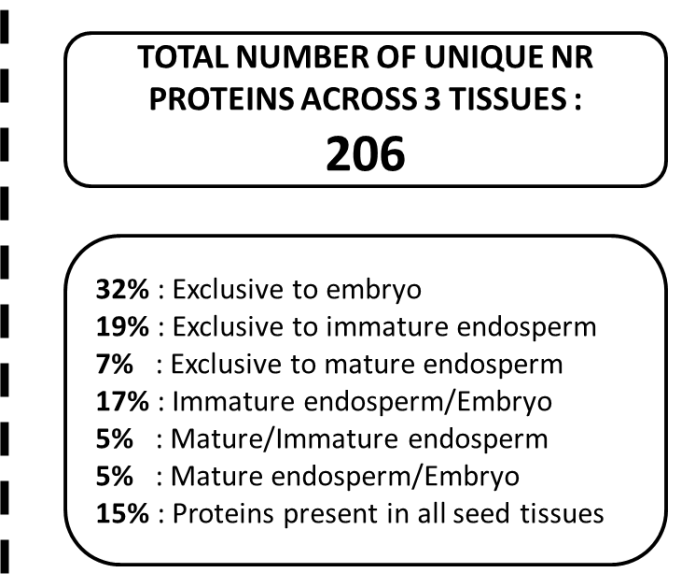

Figure 3. Venn diagram displaying distribution of non-redundant (nr) proteins amongst lotus seed immature endosperm (ImE), mature endosperm (MtE), and embryo (Emb) (a); Listing of the total and $\mathrm{nr}$ protein matches found for each lotus seed tissue analyzed (b); * see reference [17]. 


\subsection{Functional Significance of the Identified Seed Proteins}

Gene ontology data (biological processes, molecular functions and cellular localization) for all identified proteins were obtained from the UniProtKB database, using the EMBL-EBI (www.ebi.ac.uk) search tool (Table 3).

Table 3. List of all 206 non-redundant (nr) proteins found across the three tissues of the lotus seed (embryo, immature endosperm and mature endosperm).

\begin{tabular}{|c|c|c|}
\hline Protein Accession & Protein Description & Tissues $^{1}$ \\
\hline 1433E_TOBAC & 14-3-3-like protein E OS = Nicotiana tabacum & $\mathrm{M} / \mathrm{I} / \mathrm{E}$ \\
\hline HSP14_SOYBN & 17.5 $\mathrm{kDa}$ class I heat shock protein OS = Glycine $\max$ & I \\
\hline HSP11_SOLLC & $17.8 \mathrm{kDa}$ class I heat shock protein OS $=$ Solanum lycopersicum & M \\
\hline HSP11_PEA & $18.1 \mathrm{kDa}$ class I heat shock protein OS = Pisum sativum & $\mathrm{M} / \mathrm{I} / \mathrm{E}$ \\
\hline HSP12_MEDSA & $18.2 \mathrm{kDa}$ class I heat shock protein OS $=$ Medicago sativa & $\mathrm{M} / \mathrm{I}$ \\
\hline HSP11_CHERU & $18.3 \mathrm{kDa}$ class I heat shock protein OS = Chenopodium rubrum & I \\
\hline PMG1_ARATH & $\begin{array}{l}\text { 2,3-bisphosphoglycerate-independent phosphoglycerate mutase } 1 \\
\text { OS = Arabidopsis thaliana }\end{array}$ & $\mathrm{M} / \mathrm{I} / \mathrm{E}$ \\
\hline PRS6A_SOLLC & $26 \mathrm{~S}$ protease regulatory subunit $6 \mathrm{~A}$ homolog $\mathrm{OS}=$ Solanum lycopersicum & E \\
\hline RPN1A_ARATH & $26 \mathrm{~S}$ proteasome non-ATPase regulatory subunit $21 \mathrm{~A} \mathrm{OS}=$ Arabidopsis thaliana & $\mathrm{E}$ \\
\hline PRS4A_ARATH & $26 \mathrm{~S}$ proteasome regulatory subunit 4 homolog A OS $=$ Arabidopsis thaliana & $\mathrm{E}$ \\
\hline BAS1_ORYSJ & 2-Cys peroxiredoxin BAS1, chloroplastic OS = Oryza sativa subsp. Japonica & I \\
\hline RS102_ARATH & 40S ribosomal protein $\mathrm{S} 10-2 \mathrm{OS}=$ Arabidopsis thaliana & I \\
\hline RS13_PEA & 40S ribosomal protein $\mathrm{S} 13 \mathrm{OS}=$ Pisum sativum & $\mathrm{I} / \mathrm{E}$ \\
\hline RS14_CHLRE & 40S ribosomal protein $\mathrm{S} 14 \mathrm{OS}=$ Chlamydomonas reinhardtii & $\mathrm{I} / \mathrm{E}$ \\
\hline RS15A_DAUCA & 40S ribosomal protein $\mathrm{S} 15 \mathrm{a} \mathrm{OS}=$ Daucus carota & $\mathrm{E}$ \\
\hline RS16_FRIAG & 40S ribosomal protein $\mathrm{S} 16 \mathrm{OS}=$ Fritillaria agrestis & $\mathrm{I} / \mathrm{E}$ \\
\hline RS18_ARATH & 40S ribosomal protein $\mathrm{S} 18 \mathrm{OS}=$ Arabidopsis thaliana & $\mathrm{I} / \mathrm{E}$ \\
\hline RS193_ARATH & 40S ribosomal protein $\mathrm{S} 19-3 \mathrm{OS}=$ Arabidopsis thaliana & $\mathrm{I} / \mathrm{E}$ \\
\hline RS254_ARATH & 40S ribosomal protein $\mathrm{S} 25-4 \mathrm{OS}=$ Arabidopsis thaliana & $\mathrm{E}$ \\
\hline RS30_ARATH & 40S ribosomal protein $\mathrm{S} 30 \mathrm{OS}=$ Arabidopsis thaliana & $\mathrm{E}$ \\
\hline RS33_ARATH & 40S ribosomal protein $\mathrm{S} 3-3 \mathrm{OS}=$ Arabidopsis thaliana & $\mathrm{E}$ \\
\hline RS3A1_VITVI & 40S ribosomal protein $\mathrm{S} 3 \mathrm{a}-1 \mathrm{OS}=$ Vitis vinifera & I \\
\hline RS4_GOSHI & 40S ribosomal protein $\mathrm{S} 4 \mathrm{OS}=$ Gossypium hirsutum & $\mathrm{I} / \mathrm{E}$ \\
\hline RS5_CICAR & $40 \mathrm{~S}$ ribosomal protein $\mathrm{S} 5$ (fragment) $\mathrm{OS}=$ Cicer arietinum & $\mathrm{I} / \mathrm{E}$ \\
\hline RS6_ASPOF & 40S ribosomal protein $\mathrm{S} 6 \mathrm{OS}=$ Asparagus officinalis & I \\
\hline RS61_ARATH & 40S ribosomal protein S6-1 OS = Arabidopsis thaliana & $\mathrm{E}$ \\
\hline RS8_MAIZE & $40 \mathrm{~S}$ ribosomal protein $\mathrm{S} 8 \mathrm{OS}=$ Zea mays & $\mathrm{E}$ \\
\hline RS91_ARATH & 40S ribosomal protein S9-1 OS = Arabidopsis thaliana & M \\
\hline RS92_ARATH & 40S ribosomal protein S9-2 OS = Arabidopsis thaliana & $\mathrm{E}$ \\
\hline RSSA_SOYBN & $40 \mathrm{~S}$ ribosomal protein SA OS = Glycine $\max$ & $\mathrm{I} / \mathrm{E}$ \\
\hline METE_ARATH & $\begin{array}{l}\text { 5-methyltetrahydropteroyltriglutamate--homocysteine methyltransferase OS = } \\
\text { Arabidopsis thaliana }\end{array}$ & $\mathrm{M} / \mathrm{I} / \mathrm{E}$ \\
\hline RLA0_LUPLU & $60 \mathrm{~S}$ acidic ribosomal protein $\mathrm{PO} \mathrm{OS}=$ Lupinus luteus & $\mathrm{I} / \mathrm{E}$ \\
\hline RLA2_PARAR & $60 \mathrm{~S}$ acidic ribosomal protein $\mathrm{P} 2 \mathrm{OS}=$ Parthenium argentatum & $\mathrm{E}$ \\
\hline RL10_VITRI & $60 \mathrm{~S}$ ribosomal protein $\mathrm{L} 10 \mathrm{OS}=$ Vitis riparia & I \\
\hline
\end{tabular}


Table 3. Cont.

\begin{tabular}{|c|c|c|}
\hline Protein Accession & Protein Description & Tissues $^{1}$ \\
\hline RL11_MEDSA & $60 \mathrm{~S}$ ribosomal protein $\mathrm{L} 11 \mathrm{OS}=$ Medicago sativa & $\mathrm{E}$ \\
\hline RL12_PRUAR & $60 \mathrm{~S}$ ribosomal protein $\mathrm{L} 12 \mathrm{OS}=$ Prunus armeniaca & I \\
\hline RL13_TOBAC & $60 \mathrm{~S}$ ribosomal protein $\mathrm{L} 13 \mathrm{OS}=$ Nicotiana tabacum & $\mathrm{I} / \mathrm{E}$ \\
\hline RL17_MAIZE & 60S ribosomal protein $\mathrm{L} 17 \mathrm{OS}=$ Zea mays & $\mathrm{E}$ \\
\hline RL182_ARATH & $60 \mathrm{~S}$ ribosomal protein L18-2 OS = Arabidopsis thaliana & I \\
\hline RL18A_CASSA & 60S ribosomal protein L18a OS = Castanea sativa & $\mathrm{E}$ \\
\hline RL24_PRUAV & $60 \mathrm{~S}$ ribosomal protein $\mathrm{L} 24 \mathrm{OS}=$ Prunus avium & $\mathrm{E}$ \\
\hline RL3_ORYSJ & $60 \mathrm{~S}$ ribosomal protein $\mathrm{L} 3 \mathrm{OS}=$ Oryza sativa subsp. . Japonica & $\mathrm{I} / \mathrm{E}$ \\
\hline RL4_PRUAR & 60S ribosomal protein $\mathrm{L} 4 \mathrm{OS}=$ Prunus armeniaca & $\mathrm{I} / \mathrm{E}$ \\
\hline RL51_ARATH & $60 \mathrm{~S}$ ribosomal protein L5-1 OS = Arabidopsis thaliana & $\mathrm{I} / \mathrm{E}$ \\
\hline RL6_MESCR & $60 \mathrm{~S}$ ribosomal protein $\mathrm{L} 6 \mathrm{OS}=$ Mesembryanthemum crystallinum & I \\
\hline RL7A1_ARATH & 60S ribosomal protein L7a-1 OS = Arabidopsis thaliana & $\mathrm{E}$ \\
\hline ACOC_CUCMA & Aconitate hydratase, cytoplasmic OS = Cucurbita maxima & $\mathrm{M} / \mathrm{E}$ \\
\hline ACT_GOSHI & Actin OS = Gossypium hirsutum & $\mathrm{I} / \mathrm{E}$ \\
\hline ACT1_ORYSI & Actin-1 OS = Oryza sativa subsp. Indica & $\mathrm{M}$ \\
\hline ACT12_SOLTU & Actin-100 (fragment) OS = Solanum tuberosum & $\mathrm{M} / \mathrm{E}$ \\
\hline ACT1_SOLLC & Actin-41 (fragment) OS = Solanum lycopersicum & $\mathrm{M}$ \\
\hline ACT7_ARATH & Actin-7 OS $=$ Arabidopsis thaliana & M \\
\hline SAHH_MEDSA & Adenosylhomocysteinase OS $=$ Medicago sativa & $\mathrm{M} / \mathrm{I} / \mathrm{E}$ \\
\hline ADT1_GOSHI & ADP,ATP carrier protein 1 , mitochondrial OS = Gossypium hirsutum & $\mathrm{M} / \mathrm{I} / \mathrm{E}$ \\
\hline ARF_VIGUN & ADP-ribosylation factor OS = Vigna unguiculata & $\mathrm{E}$ \\
\hline SYA_ARATH & Alanine--tRNA ligase OS = Arabidopsis thaliana & $\mathrm{E}$ \\
\hline ADH1_SOLTU & Alcohol dehydrogenase $1 \mathrm{OS}=$ Solanum tuberosum & $\mathrm{M} / \mathrm{I}$ \\
\hline PHSL_IPOBA & $\begin{array}{c}\text { Alpha-1,4 glucan phosphorylase L isozyme, chloroplastic/amyloplastic OS = Ipomoea } \\
\text { batatas }\end{array}$ & $\mathrm{M} / \mathrm{E}$ \\
\hline PHSH_ARATH & Alpha-glucan phosphorylase, $\mathrm{H}$ isozyme $\mathrm{OS}=$ Arabidopsis thaliana & $\mathrm{M} / \mathrm{I}$ \\
\hline GCST_PEA & Aminomethyltransferase, mitochondrial OS = Pisum sativum & $\mathrm{I} / \mathrm{E}$ \\
\hline ANXD1_ARATH & Annexin D1 OS = Arabidopsis thaliana & $\mathrm{M} / \mathrm{I} / \mathrm{E}$ \\
\hline ANX4_FRAAN & Annexin-like protein RJ4 OS = Fragaria ananassa & $\mathrm{E}$ \\
\hline CYF_AETCO & Apocytochrome $\mathrm{fOS}=$ Aethionema cordifolium & I \\
\hline AATM_LUPAN & Aspartate aminotransferase $\mathrm{P} 2$, mitochondrial (fragment) $\mathrm{OS}=$ Lupinus angustifolius & $\mathrm{E}$ \\
\hline AATM_LUPAN & Aspartate aminotransferase $\mathrm{P} 2$, mitochondrial (fragment) $\mathrm{OS}=$ Lupinus angustifolius & I \\
\hline AAT3_ARATH & Aspartate aminotransferase, chloroplastic OS = Arabidopsis thaliana & $\mathrm{I} / \mathrm{E}$ \\
\hline AATC_DAUCA & Aspartate aminotransferase, cytoplasmic OS = Daucus carota & $\mathrm{E}$ \\
\hline PYRB_ARATH & Aspartate carbamoyltransferase, chloroplastic OS = Arabidopsis thaliana & I \\
\hline ATPAM_HELAN & ATP synthase subunit alpha, mitochondrial OS = Helianthus annuus & $\mathrm{M} / \mathrm{I} / \mathrm{E}$ \\
\hline ATPBM_NICPL & ATP synthase subunit beta, mitochondrial OS = Nicotiana plumbaginifolia & $\mathrm{M} / \mathrm{I} / \mathrm{E}$ \\
\hline ACLB1_ORYSJ & ATP-citrate synthase beta chain protein $1 \mathrm{OS}=$ Oryza sativa subsp. Japonica & $\mathrm{E}$ \\
\hline CLPA_BRANA & $\begin{array}{l}\text { ATP-dependent Clp protease ATP-binding subunit clpA homolog, chloroplastic } \\
\text { (fragment) OS = Brassica napus }\end{array}$ & I \\
\hline APBLB_ARATH & Beta-adaptin-like protein B OS = Arabidopsis thaliana & $\mathrm{E}$ \\
\hline ENO2_ARATH & Bifunctional enolase $2 /$ transcriptional activator $\mathrm{OS}=$ Arabidopsis thaliana & $\mathrm{I} / \mathrm{E}$ \\
\hline ACCC2_POPTR & Biotin carboxylase 2, chloroplastic OS = Populus trichocarpa & $\mathrm{E}$ \\
\hline CALSB_ARATH & Callose synthase $11 \mathrm{OS}=$ Arabidopsis thaliana & E \\
\hline
\end{tabular}


Table 3. Cont.

\begin{tabular}{|c|c|c|}
\hline Protein Accession & Protein Description & Tissues $^{1}$ \\
\hline CALX2_ARATH & Calnexin homolog $2 \mathrm{OS}=$ Arabidopsis thaliana & $\mathrm{E}$ \\
\hline CALR_BERST & Calreticulin OS = Berberis stolonifera & I \\
\hline CATA2_RICCO & Catalase isozyme 2 OS = Ricinus communis & $\mathrm{E}$ \\
\hline CD48A_ARATH & Cell division control protein 48 homolog A OS = Arabidopsis thaliana & $\mathrm{M} / \mathrm{I} / \mathrm{E}$ \\
\hline CLPB1_ARATH & Chaperone protein $\mathrm{ClpB} 1 \mathrm{OS}=$ Arabidopsis thaliana & $\mathrm{E}$ \\
\hline CLPC1_ARATH & Chaperone protein $\mathrm{ClpC} 1$, chloroplastic $\mathrm{OS}=$ Arabidopsis thaliana & I \\
\hline CPNA1_ARATH & Chaperonin 60 subunit alpha 1 , chloroplastic $\mathrm{OS}=$ Arabidopsis thaliana & $\mathrm{I} / \mathrm{E}$ \\
\hline CPNB3_ARATH & Chaperonin 60 subunit beta 3 , chloroplastic $\mathrm{OS}=$ Arabidopsis thaliana & $\mathrm{E}$ \\
\hline CH60A_ARATH & Chaperonin CPN60, mitochondrial OS = Arabidopsis thaliana & $\mathrm{M} / \mathrm{I} / \mathrm{E}$ \\
\hline CB2_PHYPA & Chlorophyll a-b binding protein, chloroplastic OS = Physcomitrella patens subsp. patens & I \\
\hline HSP7E_SPIOL & $\begin{array}{l}\text { Chloroplast envelope membrane } 70 \mathrm{kDa} \text { heat shock-related protein OS = Spinacia } \\
\text { oleracea }\end{array}$ & $\mathrm{M} / \mathrm{I} / \mathrm{E}$ \\
\hline HSP12_SOYBN & Class I heat shock protein (fragment) OS = Glycine max & I \\
\hline CLAH1_ARATH & Clathrin heavy chain $1 \mathrm{OS}=$ Arabidopsis thaliana & $\mathrm{I} / \mathrm{E}$ \\
\hline COPA1_ARATH & Coatomer subunit alpha-1 OS = Arabidopsis thaliana & $\mathrm{E}$ \\
\hline COB21_ORYSJ & Coatomer subunit beta-1 OS = Oryza sativa subsp. Japonica & I \\
\hline RH2_ORYSJ & DEAD-box ATP-dependent RNA helicase 2 OS = Oryza sativa subsp. Japonica & M \\
\hline DIM_PEA & Delta(24)-sterol reductase OS = Pisum sativum & $\mathrm{E}$ \\
\hline DLDH2_ARATH & Dihydrolipoyl dehydrogenase 2, mitochondrial OS = Arabidopsis thaliana & I \\
\hline OPD22_ARATH & $\begin{array}{l}\text { Dihydrolipoyllysine-residue acetyltransferase component } 2 \text { of pyruvate dehydrogenase } \\
\text { complex, mitochondrial OS = Arabidopsis thaliana }\end{array}$ & E \\
\hline EF1A_TOBAC & Elongation factor 1 -alpha OS = Nicotiana tabacum & $\mathrm{M} / \mathrm{I} / \mathrm{E}$ \\
\hline EF1D1_ORYSJ & Elongation factor 1-delta $1 \mathrm{OS}=$ Oryza sativa subsp. Japonica & $\mathrm{E}$ \\
\hline EF1G2_ORYSJ & Elongation factor 1-gamma $2 \mathrm{OS}=$ Oryza sativa subsp. Japonica & $\mathrm{M} / \mathrm{I} / \mathrm{E}$ \\
\hline EF2_BETVU & Elongation factor 2 OS = Beta vulgaris & $\mathrm{M} / \mathrm{I} / \mathrm{E}$ \\
\hline EFTM_ARATH & Elongation factor $\mathrm{Tu}$, mitochondrial $\mathrm{OS}=$ Arabidopsis thaliana & $\mathrm{E}$ \\
\hline ENPL_CATRO & Endoplasmin homolog OS = Catharanthus roseus & $\mathrm{M} / \mathrm{I} / \mathrm{E}$ \\
\hline ENO1_HEVBR & Enolase $1 \mathrm{OS}=$ Hevea brasiliensis & $\mathrm{M} / \mathrm{I} / \mathrm{E}$ \\
\hline IF4A1_ARATH & Eukaryotic initiation factor 4A-1 OS = Arabidopsis thaliana & $\mathrm{M} / \mathrm{I} / \mathrm{E}$ \\
\hline ERF1X_ARATH & Eukaryotic peptide chain release factor subunit 1-1 OS = Arabidopsis thaliana & E \\
\hline IF5A1_ARATH & Eukaryotic translation initiation factor 5A-1 OS = Arabidopsis thaliana & $\mathrm{E}$ \\
\hline ALF_CICAR & Fructose-bisphosphate aldolase, cytoplasmic isozyme OS = Cicer arietinum & $\mathrm{M} / \mathrm{I} / \mathrm{E}$ \\
\hline RFS_ORYSJ & Galactinol--sucrose galactosyltransferase $\mathrm{OS}=$ Oryza sativa subsp. Japonica & I \\
\hline GME2_ORYSJ & GDP-mannose 3,5-epimerase 2 OS = Oryza sativa subsp. Japonica & $\mathrm{E}$ \\
\hline GMD1_ARATH & GDP-mannose 4,6 dehydratase 1 OS = Arabidopsis thaliana & $\mathrm{E}$ \\
\hline GRDH1_ARATH & Glucose and ribitol dehydrogenase homolog $1 \mathrm{OS}=$ Arabidopsis thaliana & $\mathrm{M} / \mathrm{I}$ \\
\hline GLGS_BETVU & $\begin{array}{l}\text { Glucose-1-phosphate adenylyltransferase small subunit, chloroplastic/amyloplastic } \\
\text { (fragment) OS = Beta vulgaris }\end{array}$ & M \\
\hline G6PI2_CLACO & Glucose-6-phosphate isomerase, cytosolic $2 \mathrm{OS}=$ Clarkia concinna & $\mathrm{M} / \mathrm{E}$ \\
\hline GPT2_ARATH & Glucose-6-phosphate/phosphate translocator 2, chloroplastic OS = Arabidopsis thaliana & M \\
\hline GLN11_ORYSJ & Glutamine synthetase cytosolic isozyme 1-1 OS = Oryza sativa subsp. Japonica & $\mathrm{E}$ \\
\hline G3PC_ANTMA & Glyceraldehyde-3-phosphate dehydrogenase, cytosolic OS = Antirrhinum majus & $\mathrm{M} / \mathrm{I} / \mathrm{E}$ \\
\hline SYGM1_ARATH & Glycine--tRNA ligase 1, mitochondrial OS = Arabidopsis thaliana & $\mathrm{E}$ \\
\hline SSG1_HORVU & Granule-bound starch synthase 1 , chloroplastic/amyloplastic OS $=$ Hordeum vulgare & $\mathrm{M} / \mathrm{I}$ \\
\hline
\end{tabular}


Table 3. Cont.

\begin{tabular}{|c|c|c|}
\hline Protein Accession & Protein Description & Tissues $^{1}$ \\
\hline RAN_VICFA & GTP-binding nuclear protein Ran/TC4 OS = Vicia faba & $\mathrm{M} / \mathrm{I} / \mathrm{E}$ \\
\hline RAN3_ORYSI & GTP-binding nuclear protein Ran-3 OS = Oryza sativa subsp. Indica & $\mathrm{E}$ \\
\hline YPTC1_CHLRE & GTP-binding protein YPTC1 OS = Chlamydomonas reinhardtii & $\mathrm{E}$ \\
\hline GBLPA_ORYSJ & $\begin{array}{l}\text { Guanine nucleotide-binding protein subunit beta-like protein A OS = Oryza sativa } \\
\text { subsp. Japonica }\end{array}$ & I \\
\hline HSP7L_ARATH & Heat shock $70 \mathrm{kDa}$ protein $12 \mathrm{OS}=$ Arabidopsis thaliana & $\mathrm{I} / \mathrm{E}$ \\
\hline HSP7O_ARATH & Heat shock $70 \mathrm{kDa}$ protein $14 \mathrm{OS}=$ Arabidopsis thaliana & $\mathrm{I} / \mathrm{E}$ \\
\hline HSP7N_ARATH & Heat shock $70 \mathrm{kDa}$ protein $18 \mathrm{OS}=$ Arabidopsis thaliana & I \\
\hline HSP7D_ARATH & Heat shock $70 \mathrm{kDa}$ protein $4 \mathrm{OS}=$ Arabidopsis thaliana & I \\
\hline HSP7F_ARATH & Heat shock $70 \mathrm{kDa}$ protein 6 , chloroplastic $\mathrm{OS}=$ Arabidopsis thaliana & I \\
\hline HSP7G_ARATH & Heat shock $70 \mathrm{kDa}$ protein 7 , chloroplastic $\mathrm{OS}=$ Arabidopsis thaliana & $\mathrm{E}$ \\
\hline HSP70_DAUCA & Heat shock $70 \mathrm{kDa}$ protein OS = Daucus carota & $\mathrm{M} / \mathrm{I} / \mathrm{E}$ \\
\hline HSP7M_PHAVU & Heat shock $70 \mathrm{kDa}$ protein, mitochondrial OS = Phaseolus vulgaris & $\mathrm{I} / \mathrm{E}$ \\
\hline HSP80_SOLLC & Heat shock cognate protein $80 \mathrm{OS}=$ Solanum lycopersicum & $\mathrm{M} / \mathrm{I}$ \\
\hline HS101_ARATH & Heat shock protein $101 \mathrm{OS}=$ Arabidopsis thaliana & $\mathrm{M}$ \\
\hline HS101_ORYSJ & Heat shock protein $101 \mathrm{OS}=$ Oryza sativa subsp. Japonica & M \\
\hline HSP81_ORYSI & Heat shock protein 81-1 OS = Oryza sativa subsp. Indica & $\mathrm{M} / \mathrm{I} / \mathrm{E}$ \\
\hline HSP82_TOBAC & Heat shock protein 82 (fragment) OS = Nicotiana tabacum & M \\
\hline HSP82_MAIZE & Heat shock protein $82 \mathrm{OS}=$ Zea mays & $\mathrm{M} / \mathrm{I} / \mathrm{E}$ \\
\hline HSP83_IPONI & Heat shock protein $83 \mathrm{OS}=$ Ipomoea nil & $\mathrm{M} / \mathrm{I} / \mathrm{E}$ \\
\hline HS901_ARATH & Heat shock protein 90-1 OS = Arabidopsis thaliana & $\mathrm{E}$ \\
\hline HS903_ARATH & Heat shock protein 90-3 OS = Arabidopsis thaliana & I \\
\hline H2AX_CICAR & Histone $\mathrm{H} 2 \mathrm{AX}$ OS = Cicer arietinum & $\mathrm{I}$ \\
\hline H2B_GOSHI & Histone H2B OS = Gossypium hirsutum & $\mathrm{I} / \mathrm{E}$ \\
\hline H4_ARATH & Histone $\mathrm{H} 4 \mathrm{OS}=$ Arabidopsis thaliana & $\mathrm{I} / \mathrm{E}$ \\
\hline IDHC_TOBAC & Isocitrate dehydrogenase [NADP] OS = Nicotiana tabacum & $\mathrm{E}$ \\
\hline ILV5_ARATH & Ketol-acid reductoisomerase, chloroplastic OS = Arabidopsis thaliana & $\mathrm{E}$ \\
\hline APX1_ORYSJ & L-ascorbate peroxidase 1 , cytosolic $\mathrm{OS}=$ Oryza sativa subsp. Japonica & $\mathrm{E}$ \\
\hline LE194_HORVU & Late embryogenesis abundant protein B19.4 OS = Hordeum vulgare & I \\
\hline AMPL1_ARATH & Leucine aminopeptidase $1 \mathrm{OS}=$ Arabidopsis thaliana & $\mathrm{M} / \mathrm{I}$ \\
\hline BIP4_TOBAC & Luminal-binding protein OS = Nicotiana tabacum & $\mathrm{M} / \mathrm{I} / \mathrm{E}$ \\
\hline MDHC2_ARATH & Malate dehydrogenase, cytoplasmic $2 \mathrm{OS}=$ Arabidopsis thaliana & $\mathrm{M} / \mathrm{E}$ \\
\hline MDHM_CITLA & Malate dehydrogenase, mitochondrial OS = Citrullus lanatus & $\mathrm{M} / \mathrm{I} / \mathrm{E}$ \\
\hline MPPA_SOLTU & Mitochondrial-processing peptidase subunit alpha OS = Solanum tuberosum & $\mathrm{E}$ \\
\hline MDAR_SOLLC & Monodehydroascorbate reductase OS = Solanum lycopersicum & $\mathrm{I} / \mathrm{E}$ \\
\hline MAOX_POPTR & NADP-dependent malic enzyme OS = Populus trichocarpa & M \\
\hline NDK1_ARATH & Nucleoside diphosphate kinase 1 OS = Arabidopsis thaliana & $\mathrm{M} / \mathrm{I} / \mathrm{E}$ \\
\hline FKB62_ARATH & Peptidyl-prolyl cis-trans isomerase FKBP62 OS = Arabidopsis thaliana & $\mathrm{I} / \mathrm{E}$ \\
\hline PER1B_ARMRU & Peroxidase C1B OS = Armoracia rusticana & I \\
\hline CAPPC_FLATR & Phosphoenolpyruvate carboxylase $2 \mathrm{OS}=$ Flaveria trinervia & $\mathrm{E}$ \\
\hline PGMC_PEA & Phosphoglucomutase, cytoplasmic OS = Pisum sativum & $\mathrm{M} / \mathrm{I} / \mathrm{E}$ \\
\hline PGKH_TOBAC & Phosphoglycerate kinase, chloroplastic OS = Nicotiana tabacum & $\mathrm{M} / \mathrm{I}$ \\
\hline PGKY_TOBAC & Phosphoglycerate kinase, cytosolic OS = Nicotiana tabacum & $\mathrm{M} / \mathrm{E}$ \\
\hline SERC_SPIOL & Phosphoserine aminotransferase, chloroplastic OS = Spinacia oleracea & $\mathrm{E}$ \\
\hline
\end{tabular}


Table 3. Cont.

\begin{tabular}{|c|c|c|}
\hline Protein Accession & Protein Description & Tissues $^{1}$ \\
\hline PDR4_ORYSJ & Pleiotropic drug resistance protein 4 OS $=$ Oryza sativa subsp. Japonica & $\mathrm{E}$ \\
\hline PARP3_SOYBN & Poly [ADP-ribose] polymerase $3 \mathrm{OS}=$ Glycine $\max$ & I \\
\hline UBIQP_ACECL & Polyubiquitin (fragment) $\mathrm{OS}=$ Acetabularia cliftonii & I \\
\hline UBQ12_ARATH & Polyubiquitin $12 \mathrm{OS}=$ Arabidopsis thaliana & $\mathrm{E}$ \\
\hline PMG2_ARATH & $\begin{array}{l}\text { Probable 2,3-bisphosphoglycerate-independent phosphoglycerate mutase } 2 \mathrm{OS}= \\
\text { Arabidopsis thaliana }\end{array}$ & $\mathrm{M} / \mathrm{I}$ \\
\hline SSG1_ARATH & $\begin{array}{l}\text { Probable granule-bound starch synthase } 1 \text {, chloroplastic/amyloplastic OS = Arabidopsis } \\
\text { thaliana }\end{array}$ & I \\
\hline H2B1_MEDTR & Probable histone H2B.1 OS = Medicago truncatula & I \\
\hline PDIA6_MEDSA & Probable protein disulfide-isomerase $\mathrm{A6} \mathrm{OS}=$ Medicago sativa & I \\
\hline Y1497_ARATH & Probable receptor-like protein kinase At1g49730 OS = Arabidopsis thaliana & I \\
\hline PROF3_ARATH & Profilin-3 OS = Arabidopsis thaliana & $\mathrm{E}$ \\
\hline PSA3_ARATH & Proteasome subunit alpha type- 3 OS $=$ Arabidopsis thaliana & $\mathrm{E}$ \\
\hline PDI21_ORYSJ & Protein disulfide isomerase-like 2-1 OS = Oryza sativa subsp. Japonica & I \\
\hline PDI21_ARATH & Protein disulfide-isomerase like 2-1 OS = Arabidopsis thaliana & $\mathrm{M} / \mathrm{I} / \mathrm{E}$ \\
\hline ACT5_ARATH & Putative actin-5 OS = Arabidopsis thaliana & $\mathrm{I} / \mathrm{E}$ \\
\hline YCF1_IPOPU & Putative membrane protein ycf1 OS = Ipomoea purpurea & $\mathrm{M} / \mathrm{I}$ \\
\hline AVP_VIGRR & $\begin{array}{l}\text { Pyrophosphate-energized vacuolar membrane proton pump OS = Vigna radiata } \\
\qquad \text { var. radiata }\end{array}$ & $\mathrm{I} / \mathrm{E}$ \\
\hline PDC1_TOBAC & Pyruvate decarboxylase isozyme 1 (fragment) OS = Nicotiana tabacum & $\mathrm{M} / \mathrm{I}$ \\
\hline KPYC_SOYBN & Pyruvate kinase, cytosolic isozyme OS = Glycine $\max$ & $\mathrm{M} / \mathrm{I} / \mathrm{E}$ \\
\hline PPDK2_ORYSJ & Pyruvate, phosphate dikinase $2 \mathrm{OS}=$ Oryza sativa subsp. Japonica & M \\
\hline PPDK_FLABR & Pyruvate, phosphate dikinase, chloroplastic OS = Flaveria brownii & $\mathrm{M} / \mathrm{E}$ \\
\hline RAA1D_ARATH & Ras-related protein RABA1d OS = Arabidopsis thaliana & $\mathrm{E}$ \\
\hline RBL_MAIZE & Ribulose bisphosphate carboxylase large chain $\mathrm{OS}=$ Zea mays & I \\
\hline RUBA_RICCO & $\begin{array}{l}\text { RuBisCO large subunit-binding protein subunit alpha (fragment) } \mathrm{OS}=\text { Ricinus } \\
\text { communis }\end{array}$ & $\mathrm{I} / \mathrm{E}$ \\
\hline RUBB_PEA & RuBisCO large subunit-binding protein subunit beta, chloroplastic $\mathrm{OS}=$ Pisum sativum & $\mathrm{E}$ \\
\hline METK4_POPTR & S-adenosylmethionine synthase $4 \mathrm{OS}=$ Populus trichocarpa & $\mathrm{E}$ \\
\hline SAPK6_ORYSJ & Serine/threonine-protein kinase SAPK6 OS = Oryza sativa subsp. Japonica & $\mathrm{E}$ \\
\hline HSP7S_SPIOL & $\begin{array}{l}\text { Stromal } 70 \mathrm{kDa} \text { heat shock-related protein, chloroplastic (fragment) OS = Spinacia } \\
\text { oleracea }\end{array}$ & $\mathrm{I} / \mathrm{E}$ \\
\hline SUSY_SOYBN & Sucrose synthase OS = Glycine $\max$ & $\mathrm{I} / \mathrm{E}$ \\
\hline SODM_HEVBR & Superoxide dismutase $[\mathrm{Mn}]$, mitochondrial OS $=$ Hevea brasiliensis & $\mathrm{E}$ \\
\hline TCPA_ARATH & T-complex protein 1 subunit alpha OS = Arabidopsis thaliana & $\mathrm{I} / \mathrm{E}$ \\
\hline TCPE_ARATH & T-complex protein 1 subunit epsilon OS = Arabidopsis thaliana & $\mathrm{M} / \mathrm{E}$ \\
\hline TKTC_SPIOL & Transketolase, chloroplastic OS $=$ Spinacia oleracea & $\mathrm{E}$ \\
\hline TCTP_TOBAC & Translationally-controlled tumor protein homolog OS = Nicotiana tabacum & M \\
\hline TPIS_MAIZE & Triosephosphate isomerase, cytosolic OS = Zea mays & $\mathrm{I} / \mathrm{E}$ \\
\hline TBA_PRUDU & Tubulin alpha chain OS $=$ Prunus dulcis & I \\
\hline TBB_HORVU & Tubulin beta chain $\mathrm{OS}=$ Hordeum vulgare & $\mathrm{E}$ \\
\hline UBIQ_ARATH & Ubiquitin OS $=$ Arabidopsis thaliana & $\mathrm{M} / \mathrm{E}$ \\
\hline RL40A_ARATH & Ubiquitin-60S ribosomal protein L40-1 OS = Arabidopsis thaliana & $\mathrm{I} / \mathrm{E}$ \\
\hline RGP1_ORYSJ & UDP-arabinopyranose mutase $1 \mathrm{OS}=$ Oryza sativa subsp. Japonica & $\mathrm{E}$ \\
\hline UGDH_SOYBN & UDP-glucose 6-dehydrogenase OS = Glycine $\max$ & E \\
\hline
\end{tabular}


Table 3. Cont.

\begin{tabular}{ccc}
\hline Protein Accession & Protein Description & Tissues ${ }^{\mathbf{1}}$ \\
\hline UREA_CANEN & Urease OS = Canavalia ensiformis & I \\
UGPA1_ARATH & UTP--glucose-1-phosphate uridylyltransferase 1 OS = Arabidopsis thaliana & M/E \\
VATA_GOSHI & V-type proton ATPase catalytic subunit A OS = Gossypium hirsutum & I/E \\
VATB2_GOSHI & V-type proton ATPase subunit B 2 (fragment) OS = Gossypium hirsutum & E \\
VATB1_ARATH & V-type proton ATPase subunit B1 OS = Arabidopsis thaliana & E \\
WIT2_ARATH & WPP domain-interacting tail-anchored protein 2 OS = Arabidopsis thaliana & I \\
\hline
\end{tabular}

${ }^{1}$ M: Mature endosperm; I: Immature endosperm; E: Embryo.

\section{Biological Processes}

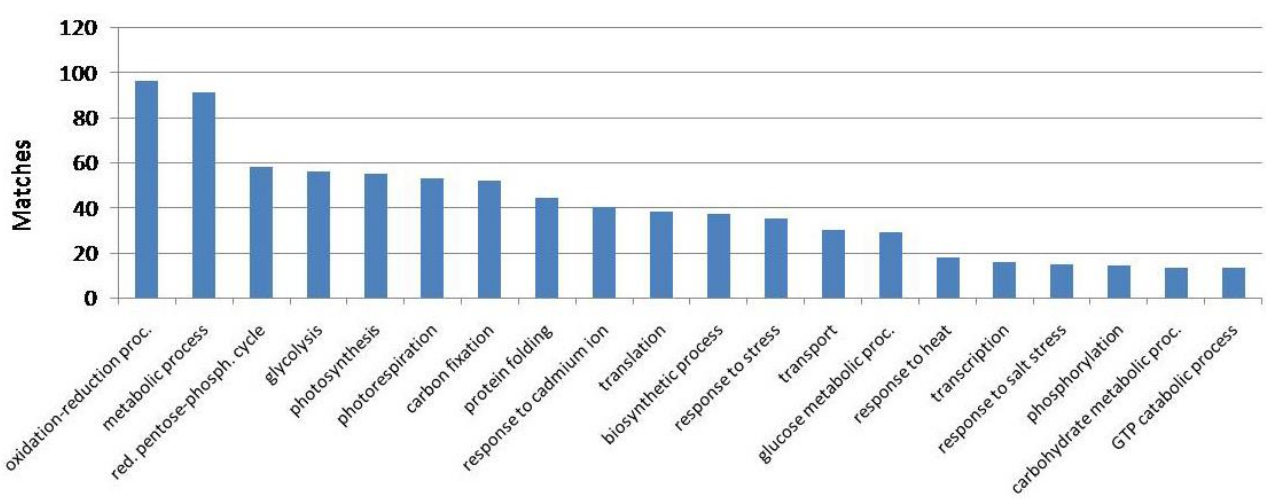

Molecular Functions

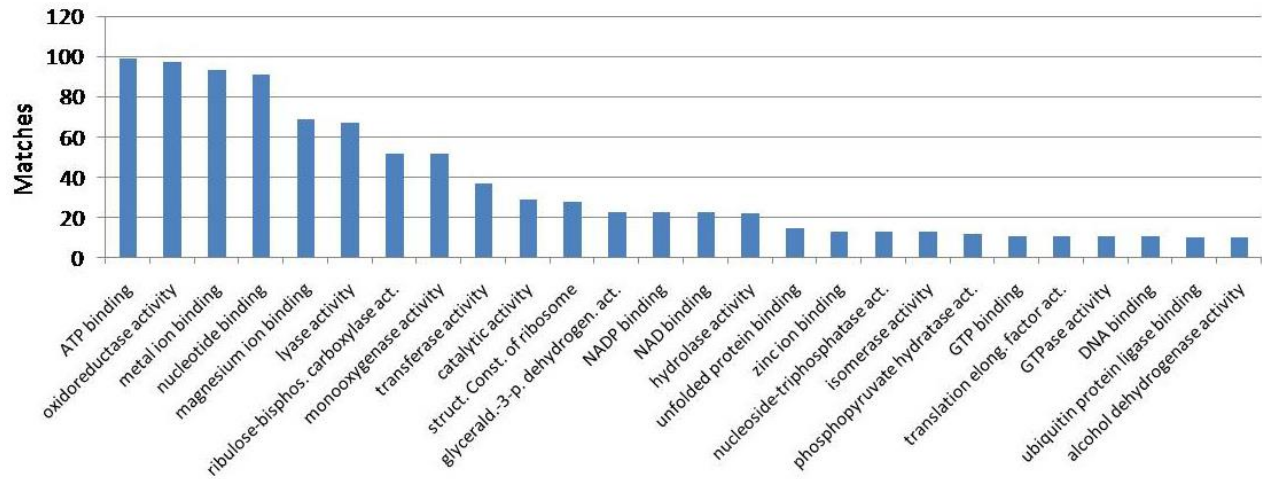

\section{Cellular Components}

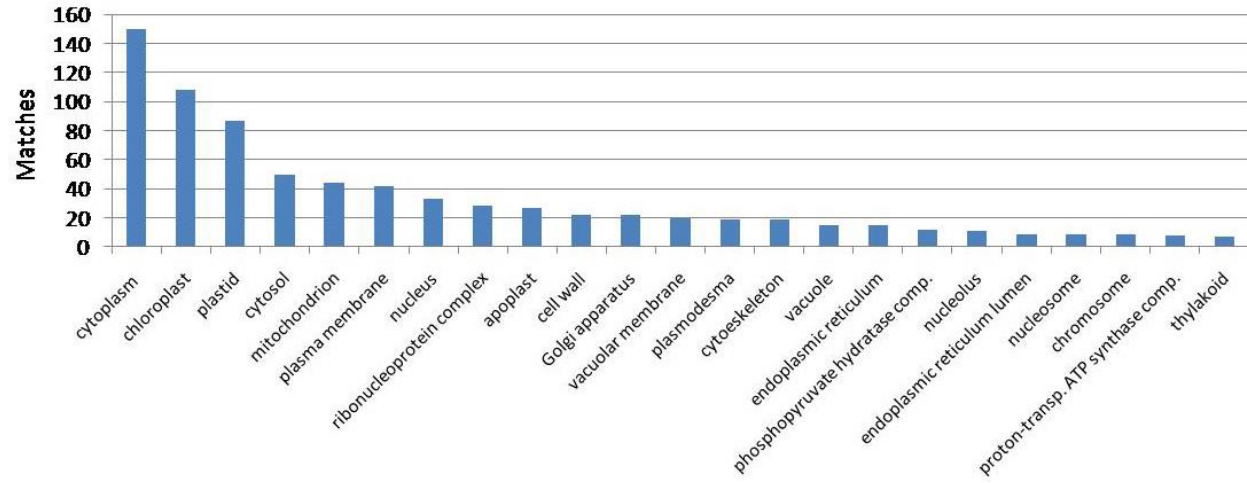

Figure 4. Distribution of the top gene ontology (GO) data for lotus immature endosperm proteome based on 1-DGE-MS analysis. 
Analysis of the annotations referent to the immature endosperm revealed that functions related to protein synthesis (translation, protein folding and polymerization, etc.), general metabolism (amino acid, carbon fixation) and carbohydrate metabolism (glycolysis, etc.) are all considerably represented, with the proteins in the first category being relatively more numerous (Figure 4).

\section{Biological Processes}

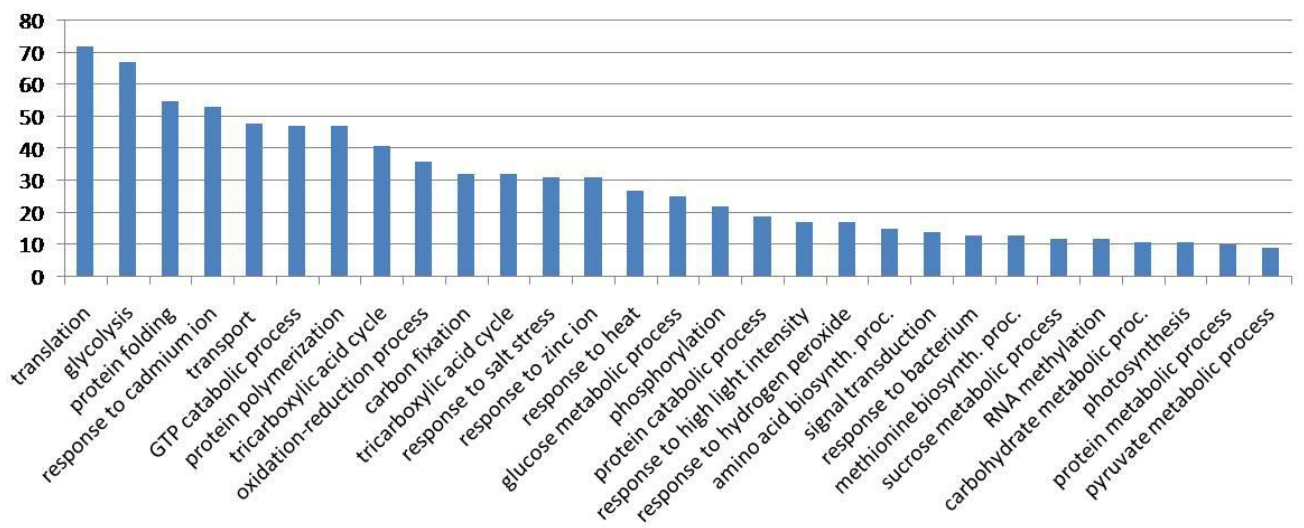

Molecular Functions

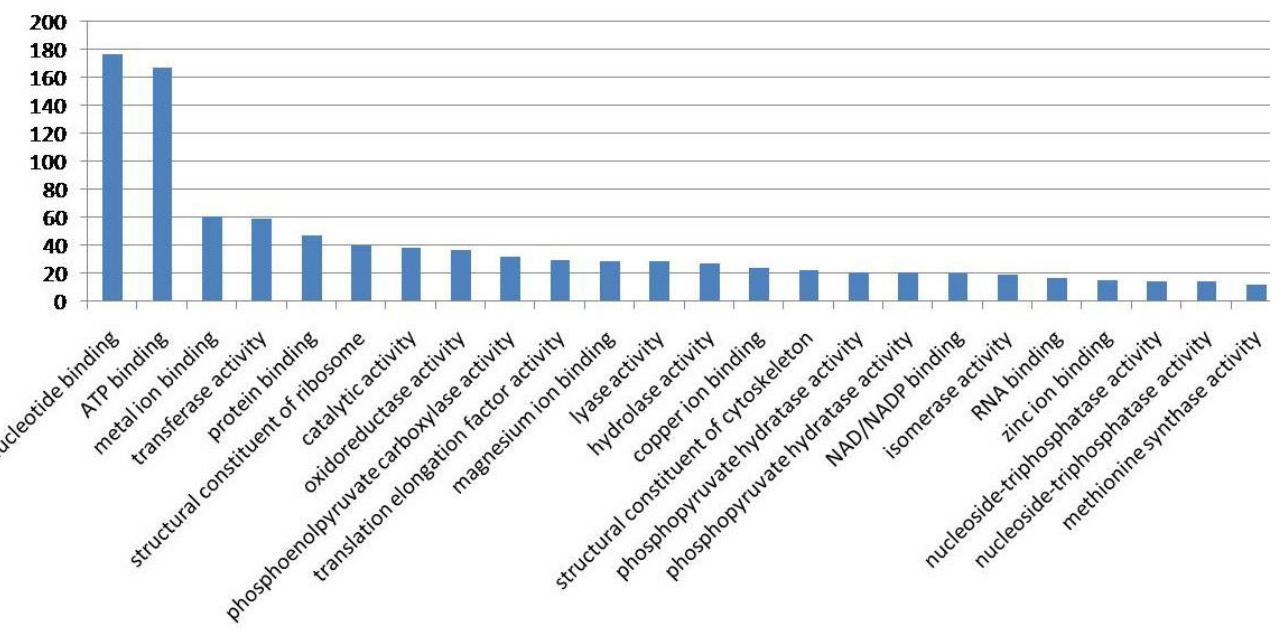

Cellular Components

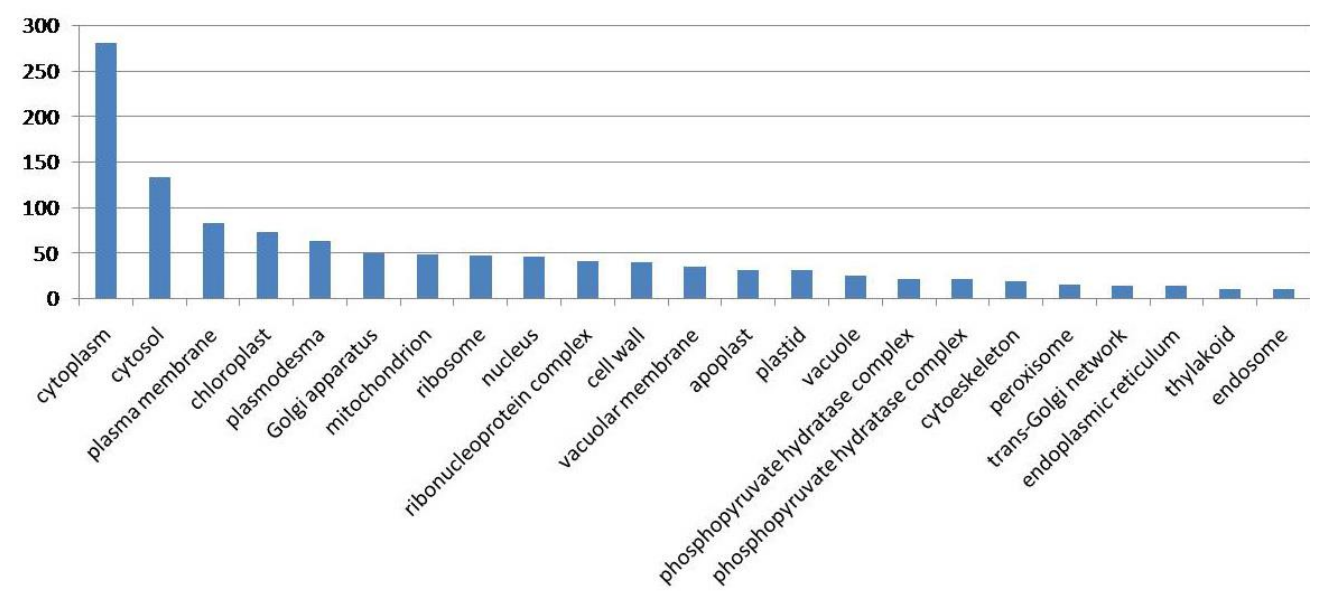

Figure 5. Distribution of the top gene ontology (GO) data for lotus embryo proteome based on 1-DGE-MS analysis. 
On the other hand, the embryo proteome shows considerable prevalence of proteins involved in protein synthesis, followed then by carbohydrate and general metabolism processes (Figure 5).

\subsection{Biological Function of the Identified Seed Proteins}

Furthermore, the $\mathrm{nr}$ protein matches were also classified according to their broader biological function [22,23], divided into 10 categories: metabolism, energy, cell growth/division, transcription, protein synthesis/destination, transporters, cell structure, signal transduction, stress response, and unclassified (Figure 6).
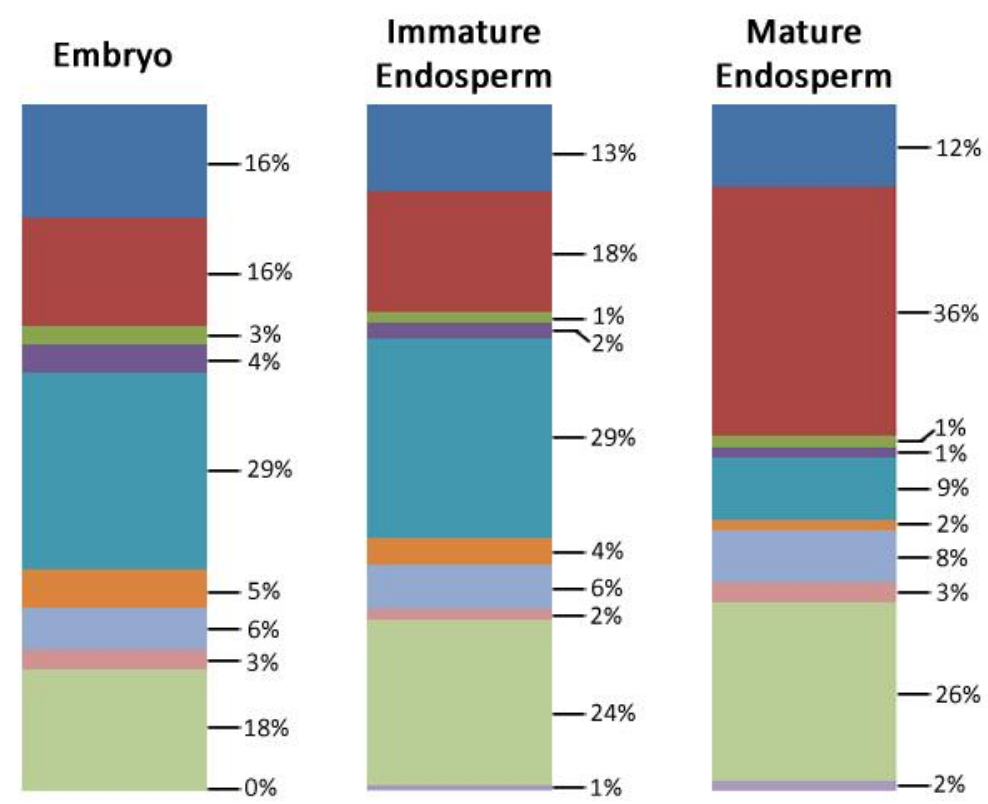

$$
\begin{aligned}
& \text { I I - Metabolism } \\
& \text { - II - Energy } \\
& \text { - III - Cell growth/division } \\
& \text { a IV - Transcription } \\
& \text { a V - Protein synthesis/destination } \\
& \text { - VI - Transport } \\
& \text { n VII - Cell structure } \\
& \text { - VIII - Signaling } \\
& \text { - IX - Stress response } \\
& \square \mathrm{X} \text { - Unclassified }
\end{aligned}
$$

Figure 6. Bar charts displaying the division according to functional categories, of the non-redundant (nr) protein matches found in the lotus seed embryo, immature endosperm, and mature endosperm, as determined by 1-DGE-MS.

A comparison of the distribution of protein functionality between the seed immature endosperm and embryo, and the previous results obtained from the mature endosperm shows that immature endosperm and embryo have a quite similar functionality profile of the mature endosperm. However, in the embryo the identified proteins related to general cell housekeeping functions (non-energy metabolism, cell growth, transcription, transport, and signaling) were slightly more apparent than in the immature endosperm. In contrast with the mature endosperm, both immature endosperm and embryo show a larger percentage of the identified proteins related to protein synthesis. This correlated well with the fact that the tissues are either in a growing phase, i.e., immature endosperm or have growth as their main function, i.e., embryo. The mature endosperm, on the other hand, having its primary function as energy and nutrient storage, has the larger share of its proteins related to energy metabolism. A common element for all the lotus seed tissues is the large presence of stress-/defense-related proteins across all samples. 


\subsection{Lotus Seed Proteome Compared with Other Seed Proteomes}

Unlike some seeds, such as tomato, where non-germinating embryo and endosperm were shown to have very similar proteomes [24], the analysis of lotus seed proteomes showed some remarkable difference in proteins identified/function between the non-germinating embryo and mature endosperm. Contrary to other seed proteomes like Jatropha curcas [23] and sugarbeet [25], the lotus embryo in its pre-germination stage did not seem to have a considerably higher expression of metabolism- and energy-related proteins compared to the mature endosperm. Structural proteins, however, did seem to be at least slightly more represented in the endosperm, as in the case of $J$. curcas. Compared with other embryo proteomes, such as Brassica campestri [26], and sugarbeet, the lotus embryo appears to have a larger percentage of proteins related to protein synthesis in comparison to primary and energy metabolism, as well as a much greater presence of defense related proteins. We further discuss below the key proteins identified in this study.

\subsection{Key Proteins of the Lotus Immature Seed Endosperm}

Contrary to the mature endosperm, the key functional proteins identified in the lotus immature endosperm mostly consisted of proteins related to plant growth and development (Figure 7).

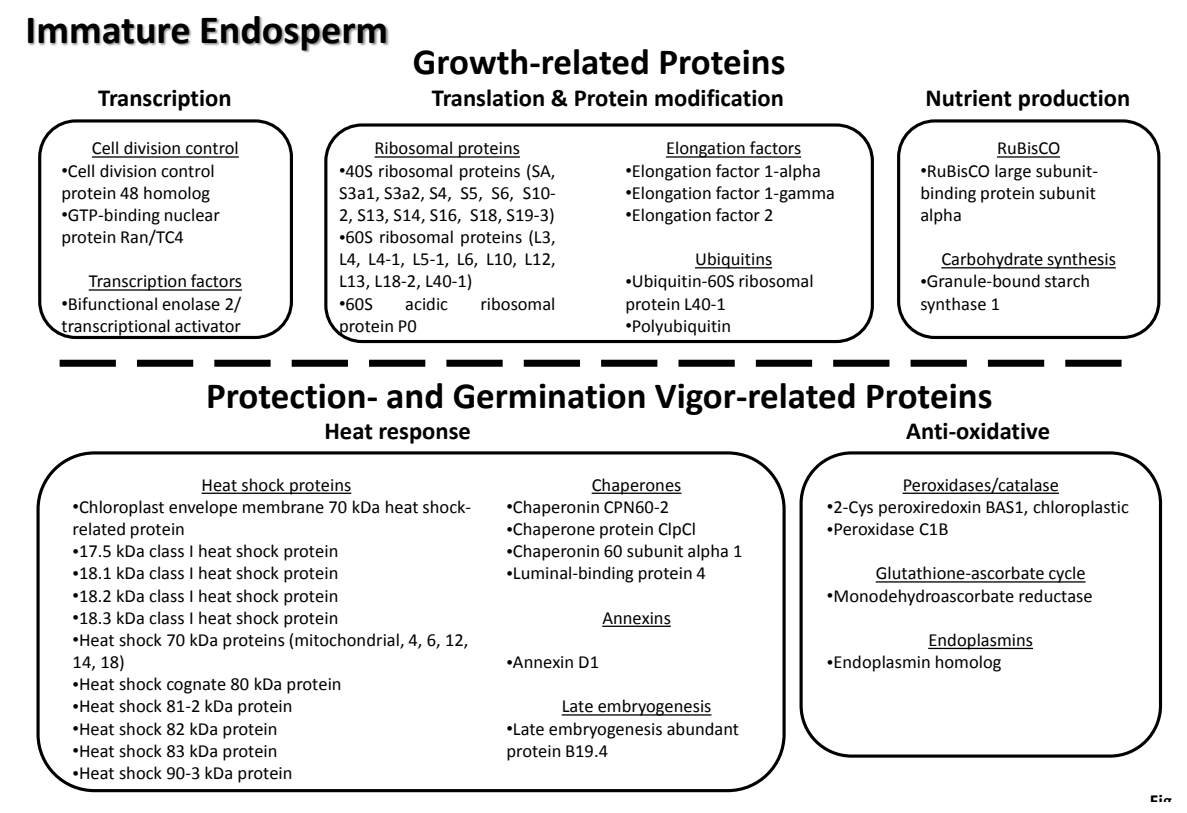

Figure 7. Key functional proteins identified in the lotus seed immature endosperm, and subdivided according to their role in plant metabolism.

Amongst the identified proteins were several transcription proteins (cell division control and transcription factors), translation (ribosomal) proteins, post-translational modification proteins (elongation factors and ubiquitins) and nutrient production proteins (RuBisCO subunits and sucrose synthase). Many stress response- and plant defense-related proteins were also present in the immature endosperm. Of these, the largest subgroup is the heat shock response proteins (high- and lowmolecular weight heat shock proteins (HSPs), as well as chaperone and annexin proteins). Antioxidative stress (peroxidases, endoplasmin, and monodehydroascorbate reductase) are also present, 
more so than in the mature endosperm (see below section). Proteins related to carbohydrate metabolism are also present in the immature endosperm, but in a smaller number.

\subsection{Key Proteins Previously Identified in the Lotus Mature Seed Endosperm}

In the case of mature endosperm proteome [17], the two most significant groups of proteins identified were related to energy/carbohydrate metabolism, and stress response and plant protection (Figure 8). In the first group, several proteins that are part of glycolysis, gluconeogenesis, citric acid cycle and starch metabolism including other carbohydrate metabolism proteins, were identified. Of the stress response proteins, HSPs, along with other heat response proteins (chaperones, annexin), constituted the most numerous category. Anti-oxidative stress proteins were not greatly represented. Of note is the identification of storage proteins (such as globulins, castanins) for the mature endosperm by 2-D MS and N-terminal sequencing, but not by 1-D MS [17,27], which might indicate a possible detection gap of this technique.

\section{Mature Endosperm*}

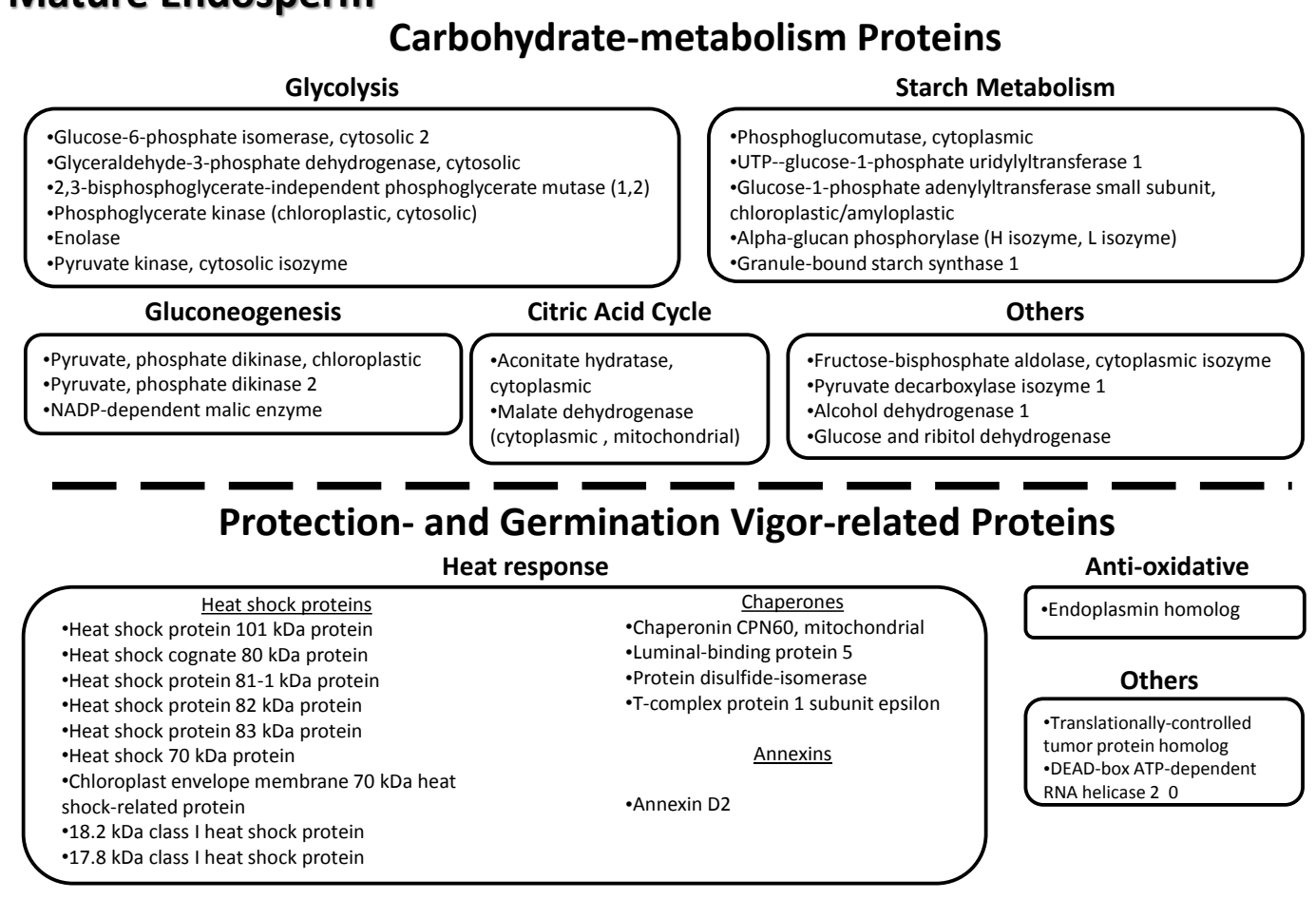

Figure 8. Key functional proteins identified in the lotus seed mature endosperm, and subdivided according to their role in plant metabolism. * for original protein lists, see reference [17].

\subsection{Proteome Changes between Mature and Immature Stages of the Endosperm}

Despite constituting the endosperm tissue samples, protein extracts from the mature and immature seed presented a notably different proteome composition (Figure 9). 


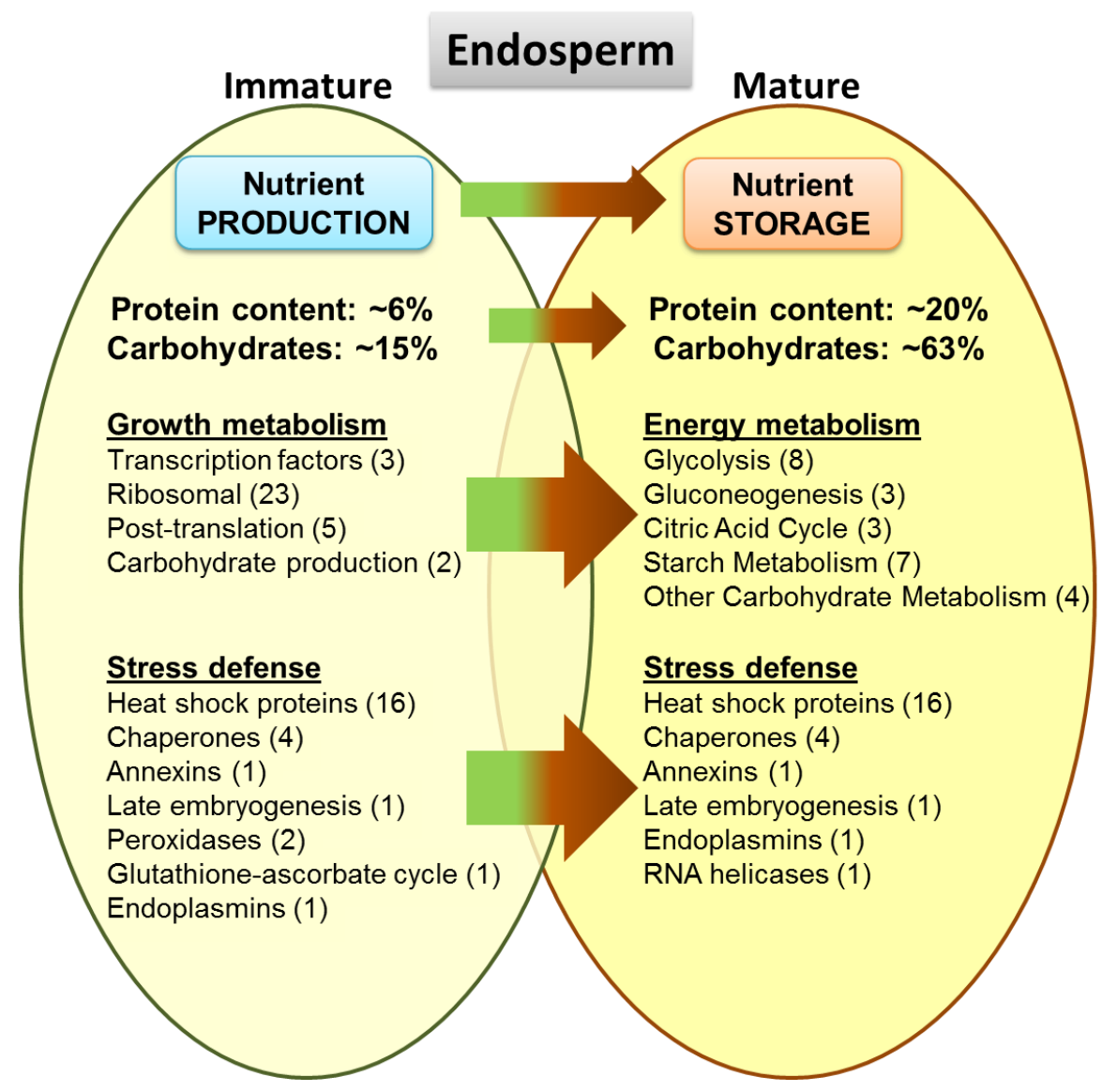

Figure 9. Depiction of the changes in biological function, nutrient content and functional proteome composition from the immature (left) to the mature (right) endosperm in the lotus seed.

This reflects the changes the endosperm undergoes during the maturation process, where it develops from a soft wet tissue to a dry one with a large amount per weight of both carbohydrates and proteins [6]. The endosperm's main role in the seed is as a nutrient storage tissue, so it is expected that during the maturation phase, these nutrients are going to be produced for later storage, hence the larger number of functional proteins related to the protein and carbohydrate synthesis categories. In the mature endosperm, a large percentage of the total protein content is expected to be seed storage proteins (SSPs). Although not many SSPs were identified by MS analysis of the mature endosperm, several possible matches were found by $\mathrm{N}$-terminal sequencing analysis [27]. The prevalence of carbohydrate metabolism proteins amongst the identified functional proteins in the mature endosperm could be a result of production in the late maturation stage, with such proteins playing a quasi-dormant role in managing the nutrient content of the seed before and during germination.

\subsection{Key Proteins of the Lotus Seed Embryo}

In the case of the embryo proteins identified by database matching, the distribution of key proteins was similar to that of the immature endosperm, in that they can be divided in the same main groups: proteins related to plant growth, and proteins responsible for plant protection and germination vigor (Figure 10). Of the first group, those also include the same subgroups of transcription, translation, and 
post-translation proteins as well as nutrient production proteins. In the case of stress/defense-related proteins, the embryo was also found to possess the largest number heat shock response proteins (12 HSPs, mostly of high-molecular weight, five chaperone proteins and two annexins). However, the embryo also contained a larger number of anti-oxidative stress proteins, including L-ascorbate peroxidase, catalase, monodehydroascorbate reductase, superoxide dismutase [Mn], and endoplasmin. $S$-adenosylmethionine synthase and adenosylhomocysteinase (also found in the endosperm tissues), and two proteins from the active methyl cycle, which is of great importance to plant metabolism as well as their nutritional value [28], were also identified in the lotus embryo.

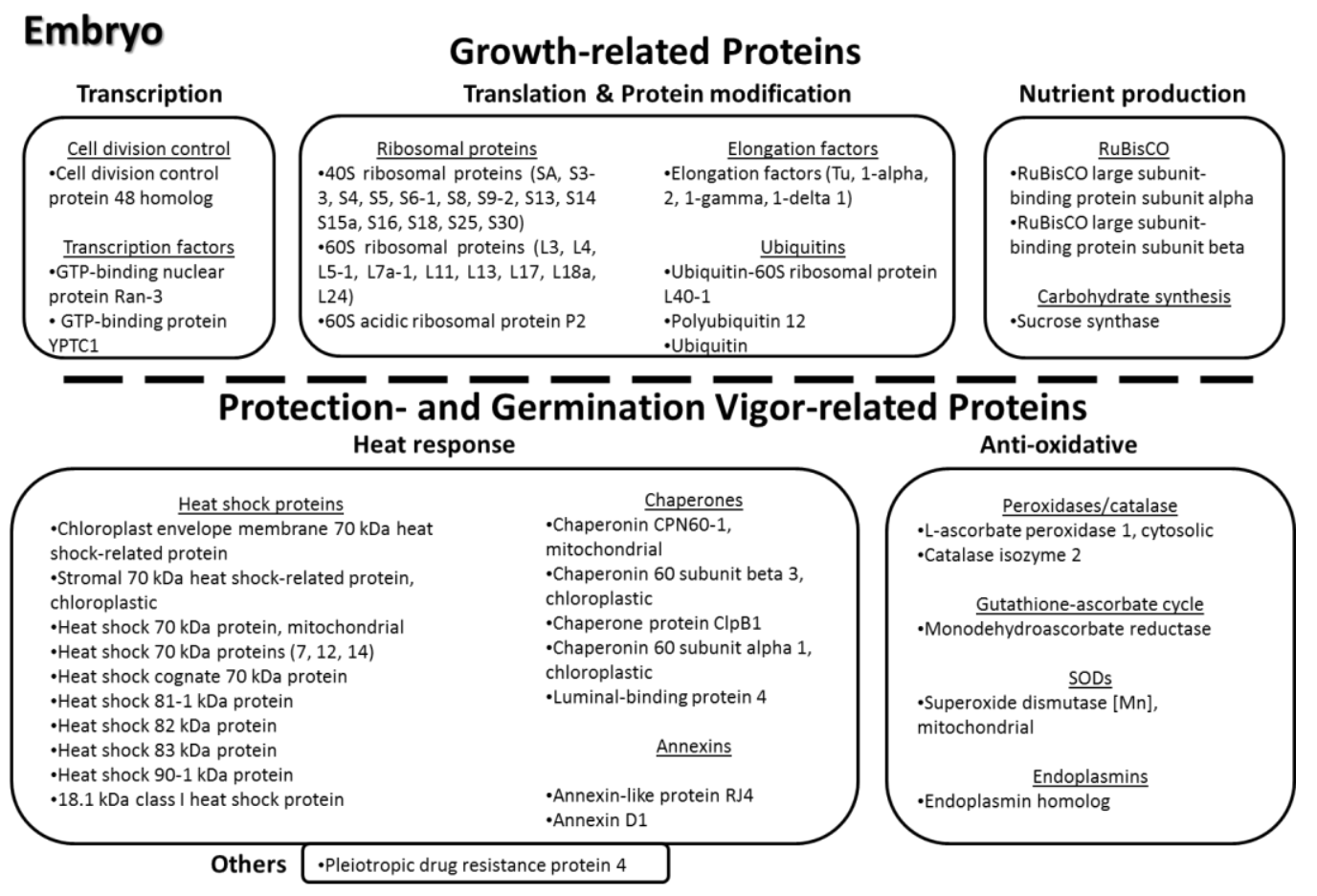

Figure 10. Key functional proteins identified in the lotus seed embryo, and subdivided according to their role in plant metabolism.

\section{Conclusions}

Analysis of protein extracts from the lotus seed embryo and immature seed endosperm was performed following 1-DGE separation in conjunction with LC-MS/MS analysis. This "bottom-up" proteomics analysis, represented by the SDS-PAGE technique, has been shown to be a good approach for identifying the lotus seed proteins [17]. For both tissues, a great number of proteins were identified by database matching. A total of $141 \mathrm{nr}$ protein matches were identified in the embryo, and 122 in the immature endosperm. Together with the 66 proteins previously identified for the mature endosperm, a total of $206 \mathrm{nr}$ proteins have been identified to date.

Combined datasets are a resource in itself towards complete proteomics analysis of lotus seeds and plants. By producing more extensive datasets, these results help toward forming a complete proteomic picture of the lotus seeds. The analysis of protein makeup and functionality across different tissues within the seed also permits a comparison of metabolic functions across different tissues and developmental stages of the lotus seed, as well as allowing for the comparison with similar tissues 
from other plants. Furthermore, the identification of proteins of interest - such as key proteins in the metabolism, proteins that confer resistance against stress or germination vigor-opens up several possibilities for more specific studies on these proteins and their possible use in producing transgenic varieties of interest.

Future work will both strive to expand the lotus proteome to other developmentally important tissues, such as seedling and rhizome, as well as to isolate and characterize functional proteins of interest in the seed proteome. Moreover, 2-DGE-MS analysis of individual proteins, especially by de novo proteome analysis techniques, coupled with genome comparison, can help obtain more detailed sequences

of lotus-specific proteins, since the high taxonomical distance of the lotus in relation to other modern plants hinders the achievement of higher homology values when database-matching proteins.

\section{Acknowledgments}

CFM greatly appreciates and acknowledges the financial support of the Japanese Ministry of Education, Culture, Sports, Science and Technology (MEXT) in the conducting this research. Authors appreciate the International Plant Proteomics Organization (INPPO) initiative (www.inppo.com) for connecting plant proteomic researchers between Brazil and Japan, and continuing collaborations between INPPO-India-Nepal chapter and INPPO-Japan.

\section{Author Contributions}

C.F.M., R.R., G.K.A., S.S., Y.K. and M.Y. were responsible for the conception of the study; C.F.M. and J.S. performed sample preparation and gel analysis; C.F.M. and Y.F. were responsible for mass spectrometry analyses; C.F.M. and R.R. performed the data analysis; C.F.M., R.R., G.K.A. and M.Y. wrote or contributed to the manuscript; figures and tables were prepared by C.F.M. and R.R. All authors read and approved the final version of the manuscript.

\section{Conflicts of Interest}

The authors declare no conflict of interest.

\section{References}

1. Sridhar, K.R.; Rajeev, B. Lotus-A potential nutraceutical source. J. Agric. Technol. 2007, 3, 143-155.

2. Pandey, B.P. Economic Botany, 5th ed.; Chand (S.) \& Co. Ltd.: New Delhi, India, 1999; p. 61.

3. Loewer, H.P. Seeds: The Definitive Guide to Growing, History and Lore, 1st ed.; Timber Press: Cambridge, UK, 2005; p. 56.

4. Shen-Miller, J.; Schopf, J.W.; Harbottle, G.; Cao, R.J.; Ouyang, S.; Zhou, K.S.; Southon, J.R.; Liu, G.H. Long-living lotus: germination and soil $\gamma$-irradiation of centuries-old fruits, and cultivation, growth, and phenotypic abnormalities of offspring. Am. J. Bot. 2002, 89, 236-247. 
5. Shen-Miller, J.; Aung L.H.; Turek, J.; Schopf, J.W.; Tholandi, M.; Yang, M.; Czaja, M. Centuries-old viable fruit of sacred lotus Nelumbo nucifera Gaertn var. China antique. Trop. Plant Biol. 2013, 6, 53-68.

6. MEXT-Ministry of Education, Culture, Sports, Science and Technology; Standard Tables of Food Composition in Japan, 5th ed.; MEXT: Tokyo, Japan, 2000.

7. Guo, H.B. Cultivation of lotus (Nelumbo nucifera Gaertn. ssp. nucifera) and its utilization in China. Gen. Res. Crop Evol. 2009, 56, 323-330.

8. Komatsu, E.; Tsukahara, A.; Amagaya, H.; Okazawa, N.; Noguchi, T.; Okuyama, T. Lotus. In The Cultivation and Management in Aquatic Vegetables; Izaki, M., Ed.; Ie-No-Hikari Kyokai Press: Tokyo, Japan, 1975; Volume 1, pp. 9-94.

9. Ling, Z.Q.; Xie, B.J.; Yang, E.L. Isolation, characterization, and determination of antioxidative activity of oligomeric procyanidins from the seedpod of Nelumbo nucifera Gaertn. J. Agric. Food Chem. 2005, 53, 2441-2445.

10. Ou, M. Chinese-English Manual of Commonly-Used in Traditional Chinese Medicine; Joint Publishing Co. Ltd.: Hong Kong, China, 1989.

11. Moro, C.F., Yonekura, M., Kouzuma, Y., Agrawal, G.K., Rakwal, R. Lotus-A source of food and medicine: Current status and future perspectives in context of the seed proteomics. Int. J. Life Sci. 2013, 7, 1-5.

12. Ming, R.; Vanburen, R.; Liu, Y.; Yang, M.; Han, Y.; Li, L.T.; Zhang, Q.; Kim, M.J.; Schatz, M.C.; Campbell, M.; et al. Genome of the long-living sacred lotus (Nelumbo nucifera Gaertn.). Genome Bio. 2013, 14, doi:10.1186/gb-2013-14-5-r41.

13. Dong, C.; Zheng, X.; Li, G.; Zhu, H.; Zhou, M.; Hu, Z. Molecular cloning and expression of two cytosolic copper-zinc superoxide dismutases genes from Nelumbo nucifera. Appl. Biochem. Biotechnol. 2010, 163, 679-691.

14. Zhou, Y.; Chen, H.; Chu, P.; Li, Y.; Tan, B.; Ding, Y.; Tsang, E. W. T.; Jiang, L.; Wu, K.; Huang, S. NnHSP17.5, a cytosolic class II small heat shock protein gene from Nelumbo nucifera, contributes to seed germination vigor and seedling thermotolerance in transgenic Arabidopsis. Plant Cell Rep. 2012, 31, 379-389.

15. Liu, Z.; Gu, G.; Chen, F.; Yang, D.; Wu, K.; Chen, S.; Jiang, J.; Zhang, Z. Heterologous expression of a Nelumbo nucifera phytochelatin synthase gene enhances cadmium tolerance in Arabidopsis thaliana. Appl. Biochem. Biotechnol. 2012, 166, 722-734.

16. Chu, P.; Chen, H.; Zhou, Y.; Li, Y.; Ding, Y., Jiang, L.; Tsang, E. W.; Wu, K.; Huang, S. 2012. Proteomic and functional analyses of Nelumbo nucifera annexins involved in seed thermotolerance and germination vigor. Planta 2012, 235, 1271-1288.

17. Moro, C.F.; Fukao, Y.; Shibato, J.; Rakwal, R.; Timperio, A.M.; Zolla, L.; Agrawal, G.K.; Shioda, S.; Kouzuma, Y.; Yonekura, M. Unraveling the seed endosperm proteome of the lotus (Nelumbo nucifera Gaertn.) utilizing 1DE and 2DE separation in conjunction with tandem mass spectrometry. Proteomics 2015, 15, 1717-1735.

18. Bradford, M.M. A rapid and sensitive method for the quantitation of microgram quantities of protein utilizing the principle of protein-dye binding. Anal. Biochem. 1976, 72, 248-254.

19. Wang, X.; Li, X.; Li, Y. A modified Coomassie Brilliant Blue staining method at nanogram sensitivity compatible with proteomic analysis, Biotech. Lett. 2007, 29, 1599-1603. 
20. Horie, K.; Rakwal, R.; Hirano, M.; Shibato, J.; Nam, H.W.; Kim, Y.S., Kouzuma, Y.; Agrawal, G.K.; Masuo, Y.; Yonekura, M. Proteomics of two cultivated mushrooms Sparassis crispa and Hericium erinaceum provides insight into their numerous functional protein components and diversity. J. Proteome Res. 2008, 7, 1819-1835.

21. Yates, J.R.; Ruse, C.I.; Nakorchevsky, A. Proteomics by mass spectrometry: Approaches, advances, and applications. Ann. Rev. Biomed. Eng. 2009, 11, 49-79.

22. Bevan, M.; Bancroft, I.; Bent, E.; Love, K.; Goodman, H.; Dean, C.; Bergkamp, R.; Dirkse, W.; van Staveren, M.; Stiekema, W.; et al. Analysis of $1.9 \mathrm{Mb}$ of contiguous sequence from chromosome 4 of Arabidopsis thaliana. Nature 1998, 391, 485-488.

23. Liu, H.; Yang, Z.; Yang, M; Shen, S. The differential proteome of endosperm and embryo from mature seed of Jatropha curcas. Plant Sci. 2011, 181, 660-666.

24. Sheoran, I.S.; Olson, D.J.; Ross, A.R.; Sawhney, V.K. Proteome analysis of embryo and endosperm from germinating tomato seeds. Proteomics 2005, 5, 3752-3764.

25. Catusse, J.; Strub, J.M.; Job, C.; Dorsselaer, A.; Job, D. Proteome-wide characterization of sugarbeet seed vigor and its tissue specific expression. Proc. Natl. Acad. Sci. U.S.A. 2008, 105, 10262-10267.

26. Li, W.; Gao, Y.; Xu, H.; Zhang, Y.; Wang, J. A proteomic analysis of seed development in Brassica campestri L. PLoS ONE 2012, 7, e50290.

27. Moro, C.F. Study of the Lotus (Nelumbo nucifera Gaertn.) Seed Proteome. Ph.D. Thesis, Tokyo University of Agriculture and Technology, Tokyo, Japan, March 2015.

28. Ravanel, S.; Gakière, B.; Job, D.; Douce, R. The specific features of methionine biosynthesis and metabolism in plants. Proc. Natl. Acad. Sci. U.S.A. 1998, 95, 7805-7812.

(C) 2015 by the authors; licensee MDPI, Basel, Switzerland. This article is an open access article distributed under the terms and conditions of the Creative Commons Attribution license (http://creativecommons.org/licenses/by/4.0/). 